\title{
Concentration of Platinum Group Elements during the Early Earth Evolution: A Review ${ }^{*}$
}

\author{
Arkady Pilchin1, Lev Eppelbaum² \\ ${ }^{1}$ Universal Geoscience and Environment Consulting Company, Willowdale, Ontario, Canada \\ ${ }^{2}$ Department of Geosciences, Faculty of Exact Sciences, Tel Aviv University, Tel Aviv, Israel \\ Email:levap@post.tau.ac.il
}

How to cite this paper: Pilchin, A. and Eppelbaum, L. (2017) Concentration of Platinum Group Elements during the Early Earth Evolution: A Review. Natural Resources, 8, 172-233.

https://doi.org/10.4236/nr.2017.83012

Received: February 6, 2017

Accepted: March 28, 2017

Published: March 31, 2017

Copyright $\odot 2017$ by authors and Scientific Research Publishing Inc. This work is licensed under the Creative Commons Attribution International License (CC BY 4.0).

http://creativecommons.org/licenses/by/4.0/

\begin{abstract}
Numerous unique geological processes [1] took place during the early Earth evolution; several of them, especially those occurring in the Hadean-Early Archean and later, are reflected in the modern geological (geophysical, geochemical, etc.) pattern. One such significant enigmatic feature is the preservation of extremely dense and heavy platinum group elements (PGEs): Pt, Pd, $\mathrm{Rh}, \mathrm{Ru}, \mathrm{Ir}$, Os. Concentration of PGEs during this period could have taken place in two ways: 1) presence of particular matter capable of preserving PGEs near the earth's surface, 2) transportation of PGEs by magma flows from deep lithospheric (asthenospheric) layers (slabs) to the subsurface. Clearly, much of the dense and heavy PGEs did not sink through to the Earth's mantle (core) at the time of the magma-ocean, and occur near Earth's surface in abundances for formation of ore deposits with PGE concentrations found to be 2 - 3 orders of magnitude greater than those in their host media. Their enrichments are associated in numerous cases with such enigmatic phenomena as formation of anorthosites and anorthosite-bearing layered magmatic intrusions. PGE deposits and mineralization zones are also found in associations with chromitites, dunites and serpentinites. In this review, problems related to the initial concentration and preservation of PGEs, their association with anorthosites, and formation of layered intrusions are discussed in detail. The main aim of this article is analysis of the requirements-initial concentration and preservation of PGE and PGM (Platinum Group Minerals) during the early Earth evolution, as well as examination of the distribution behavior of some PGEs in different ore deposits and meteorites. It is supposed that meteoritic bombardment of Earth has played a significant role in formation of PGEs deposits. Some conclusions made in this article may be useful for developing and enhancing strategies of prospecting for PGEs deposits.
\end{abstract}

\section{Keywords}

Platinum Group Elements, Early Earth Evolution, Magma-Ocean, Earth's Bombardment, PGE Deposit Formation 


\section{Introduction}

A significant enigmatic feature of early Earth evolution is the preservation of extremely dense and heavy platinum group elements (PGE): Pt, Pd, Rh, Ru, Ir, Os, which somehow managed not to sink to the Earth's core throughout the duration of the magma-ocean, and instead were accumulated at relatively small depths in quantities yielding formation of economic ore deposits. In numerous cases, their enrichments are associated with such enigmatic rock formations as anorthosites, and such inscrutable magmatic structures as layered magmatic intrusions (layered mafic-ultramafic intrusions). Despite that PGEs mining has a very long history, specific aspects of PGE ore formation still remain the subject of great controversy (e.g., [2] [3]).

Any genesis model of ore deposits usually includes such components as source, transport and trap (e.g., [4]). However, certain authors (e.g., [5]) indicate that formation of any ore deposit includes four basic geological requirements: 1) source of metals and ligands (e.g., sulfur and chlorine), 2) mechanism which either transports these source components or removes non-ore components to allow residual concentration of metals, 3) trap (depositional mechanism for formation of the ore body as ore minerals and associated gangue), and 4) conditions necessary for preservation of the ore deposit. Most such models are usually oversimplified, since different ore deposits have different specifications for their formation, various classifications, different types of mineralization, etc. (e.g., [5]). However, for formation of economic PGE ore deposits, another requirement must be emphasized. A mechanism is necessary for the enrichment of ore metal(s) concentration in ore deposits of up to 3 - 4 orders of magnitude greater than their typical crustal abundances (e.g., [3]). The concentration of platinum in areas exposed to earth's surface is about $0.4 \mathrm{ppb}$ [3]. This means that such requirement as process (processes) of extraction of PGE metals from the source rocks and minerals must also be taken into consideration.

Experimental data show that at equilibrium conditions, the concentration of all PGEs is at least 10,000 times higher in sulfide melt than in the coexisting silicate melt, making sulfide an extremely potent agent for the collection and segregation of PGEs from magmas [3]. This means that known associations of PGEs with sulfide deposits [6] are not accidental and should rather be expected. For example, in anorthosite-bearing layered mafic and ultramafic intrusions (ALMI) of Australia stratabound layers of disseminated $\mathrm{Ni}-\mathrm{Cu}$ sulfides enriched in PGEs, stratabound chromitite layers (the Panton Sill in the Halls Creek orogen, with PGE-rich sulfides) and basal segregations of $\mathrm{Ni}-\mathrm{Cu}$-Co-PGE sulfides have been reported in anorthosite-bearing layered mafic and ultramafic intrusions (ALMI) of Australia [7]. Moreover, it has been proposed that chromitites owe their high Pt (and Pd) content to segregation of the magmatic sulfides during chromite precipitation [8]. However, on other hand, the most important deposits occur as relatively narrow stratiform reefs, which tend to be sulfide-poor (e.g., [2]); and the rocks contain no visible sulfides in many chromitites, magnetitites and silicate-hosted ores [2]. Chromitites from dunites in the *This article is dedicated to the memory of Dr. Arkady Pilchin. 
Uktus Ural- Alaskan type complex (the Urals, Russia) are characterized by high Pt contents, even though there is no evidence of attaining sulfur saturation during their formation [9]. Maier [2] also points to low sulfide contents of many PGE-rich intrusions. PGEs are known to be present in rocks as inclusions of native metals and alloys, as well. A sulfide-free upper zone is reported in the South Kawishiwi Intrusion of the Duluth Complex (Minnesota, USA) [10]. PGE mineralization occurs within a sulfide-free magmatic environment in the Mid-Archean Bangur Gabbro (Orissa, India) [11]. Sulfur-poor intrusions are known in the Ural Pt-belt (Russia) [12]. PGE deposits of Sukhoy Log, Bodaybinski area (Irkutsk region, Russia) were discovered in the black schists with PGEs concentrations of up to $1.7 \mathrm{~g} / \mathrm{t}$ [13] [14].

Chernyshov [15] reported a number of structural complexes of different age (from Early Archean to Early Proterozoic) containing Au-PGE mineralization in association with the high carbon formations (e.g., graphitized gneisses, carbon-rich schists) in the Voronezh Crystalline Massif (Russia). Here the ore deposits include Pd-containing ( $\mathrm{Pd}$ up to $1.2 \mathrm{~g} / \mathrm{t}$ and $\mathrm{Pt}$ up to $0.3 \mathrm{~g} / \mathrm{t}$ ) ferruginous quartzites of Kursk series.

Chernyshov and Chernyshova [16] described gold-PGEs mineralization (Oboyansky type) in the Early Archean graphitized gneisses of the Voronezh Crystalline Massif with concentration of PGEs of $\sim 5 \mathrm{~g} / \mathrm{t}$ and $\mathrm{Au}$ of $1.3-1.5 \mathrm{~g} / \mathrm{t}$.

Houlé and Lesher [17] show that from four major volcanic episodes involving komatiites in the Abitibi Greenstone Belt (Superior Province, Canada) (2760 2735, $2723-2720,2720-2710$, and $2710-2704 \mathrm{Ma}$ ), the last two alone host nearly the entire $\mathrm{Ni}-\mathrm{Cu}$-(PGE) inventory of the belt.

This is a common problem with development of any model of the formation of PGE ore deposits. The Bushveld Complex in South Africa has highest content of PGEs and platinum group minerals (PGM) in the world (e.g., [3] [18]), known to contain overwhelming deposits of PGEs and chromium (over $80 \%$ of the world's deposits of each) [18] [19]. USGS [20] states that $~ 88.7 \%$ of the global PGE reserves are concentrated in the South Africa and most of them belong to the Bushveld Igneous Complex. These facts contradict any standard model of ore deposit formation, because it is very difficult to explain why these vast amounts of PGEs and Cr should be collected in a single area of the Earth.

Another problem of PGE ore deposit formation relates to the fact that most of siderophile (Fe-lowing) elements (e.g., Sn, Mo, Au, and the PGEs) may be locked away in the core, causing their crustal abundances to be much less than those of the global bulk (e.g., [21]). This problem is especially significant for formation of PGE ore deposits, because the densities of PGEs are extremely high (Table 1). This creates another requirement for PGE ore deposit formation: the initial concentration of the PGEs and PGMs during the early Earth evolution and their preservation as sources for the formation of PGE ore deposits. It is self-evident that the initial concentration of PGEs and PGMs is one of the most important processes for formation of PGE deposits, which allowed for later formation of PGE ore deposits.

In many cases, extremely high concentrations of PGEs found in different re 
Table 1. Densities and melting points at $0.1 \mathrm{MPa}$ (after [22]) and condensation temperatures at $10^{-5} \mathrm{MPa}$ (after [23]) of PGE.

\begin{tabular}{|c|c|c|c|c|c|c|}
\hline Element & $\mathrm{Pd}$ & $\mathrm{Pt}$ & $\mathrm{Rh}$ & $\mathrm{Ru}$ & Ir & Os \\
\hline Density, $\mathrm{kg} / \mathrm{m}^{3}$ & 12,000 & 21,500 & 12,400 & 12,100 & 22,500 & 22,590 \\
\hline Melting point, $\mathrm{K}$ & 1827.95 & 2031.35 & 2236.15 & 2606.15 & 2719.15 & 3306.15 \\
\hline $\begin{array}{l}\text { Condensation } \\
\text { temperature, } \mathrm{K}\end{array}$ & 1324 & 1408 & 1392 & 1551 & 1603 & 1812 \\
\hline
\end{tabular}

gions of the Earth have no relations to any ore deposits. For example, PGE resources in China are relatively poor, and are mainly concentrated in the Jinchuan $\mathrm{Cu}-\mathrm{Ni}$ deposit where in disseminated ores $\Sigma$ PGE ranges within $98-7159 \mathrm{ppb}$ but does not reach a level of economic deposit [24]. Such a situation prompts a question: how is it possible that PGE concentrations within the same deposit varies from poor (98 ppb) to very rich (7159 ppb)?

All this is highly controversial and problematic for any modeling of formation of economic PGE deposits, and renders the problem of generation of PGE ore deposit as enigmatic.

The main aim of this investigation is not related to the creation of any new model of PGE ore deposit formation, but rather to the analysis of the requirements-initial concentration and preservation of PGEs and PGMs during the early Earth evolution, and analysis of certain patterns in the distribution of PGEs in different ore deposits and meteorites.

It is clear that all matter on Earth came from within the solar nebula by the in-falling of nebular material onto the evolving planet during its accretion, at the end of which Earth was covered with a magma-ocean about $1000 \mathrm{~km}$ deep [1]. This means that in order to accumulate significant amounts of PGEs and PGMs near Earth's surface, there must have been certain mechanisms of their concentration in near-surface layers, their trapping, and preservation for the future formation of PGE ore deposits.

\section{On the Formation of PGEs and PGMs and Their Content in Rocks and Meteorites}

It is widely accepted that PGEs, like any other elements with an atomic number greater than that of iron (A > 26), were formed by the supernova explosion (e.g., [25]). This means that the real source of PGEs was a supernova explosion. Other than Palladium, all PGEs including PPGEs (Palladium (Pd), Platinum (Pt), Rhodium (Rh)) and IPGEs (Ruthenium, Iridium and Osmium) are refractory elements, most of which were condensed in refractory mineral alloys [23] at temperatures (see Table 1) within the range of the formation of calcium-aluminum inclusions (CAIs) (1473 - $2273 \mathrm{~K}$; [26]), and those above the formation of chondrules (over $1473 \mathrm{~K}$; [26]).

The extraordinarily high melting points of PGEs (see Table 1) make it impossible for most of them to be present in molten state in any kind of magmatic rocks. Only Pd can be melted by some Mg-rich komatiites, and both Pd and Pt may be present in the molten form in some chromites and molten forsterite. 
This means that the most PGMs would accrete on the Earth or any other terrestrial object in solid state. However, the initial formation of PGMs (mostly as alloys and solid solutions) requires their components to be molten and then cooled, and solidifying very quickly because of the huge difference in melting points. This could have taken place only in two ways: 1) during the cooling of matter from the supernova explosion, when the temperatures dropped to those of the melting points or condensation temperatures of PGEs and certain other metals; or 2) during the beginning of solar accretion, when previously cooled matter within the solar nebula was once again heated to the melting points or condensation temperatures of PGEs and certain other metals, with a subsequent ejection of the formed alloys into the range of the forming terrestrial planets and asteroid belt, similar to the process of the formation and transportation of CAIs described in [27].

For metals having such a vast difference in melting points, the unusual polygonal intergrowth of osmium, iridium and ruthenium with Pt-Fe alloy observed within grains in the Aikora River area of Papua New Guinea [28] indicates their formation took place with rapid cooling of the molten metals. Inclusions of PGEs and their alloys within the Pt-Fe alloys were reported from Florence Creek, Yukon (Ir-dominant alloys; [29]) and Novoseltsi placers of eastern Bulgaria (Os and Os-dominant alloys; [30]). A comparison of the melting points of PGEs reveals (see Table 1) that these inclusions of Ir- and Os-dominant alloys were added to the Pt-Fe alloy melt in solid state.

PGE contents in different kinds of terrestrial rocks indicate (Table 2) that their content in the main magmatic rock composing the Earth crust and upper mantle is extremely low.

This renders it very difficult to assess the source of the PGEs for known ore mineralization and deposits with concentrations as high as: average grades of 3 20 ppm for PGEs + Au in the PGE reefs [38]; up to 18 ppm in the Monchegorsk area of the Kola Peninsula (Russia) [39]; up to $61 \mathrm{ppm}$ in the Kytlym area of the Northern Urals (Russia) [40]; up to over $60 \mathrm{ppm}$ of Pt + Pd in Cliff from Shet

Table 2. PGE contents in different kinds of terrestrial rocks.

\begin{tabular}{cccccccc}
\hline \multirow{2}{*}{ Rocks } & \multicolumn{7}{c}{ Concentration, in ppb } \\
\cline { 2 - 7 } & Pt & Pd & Rh & Ru & Ir & Os & References \\
\hline Primary mantle & 7.1 & 3.9 & 0.9 & 5 & 3.2 & 3.4 & {$[31]$} \\
Bulk crust & 1.5 & 1.5 & 1.1 & 0.6 & 0.037 & 0.041 & {$[32]$} \\
Upper mantle peridotite & 6.5 & 5.7 & 0.6 & 5.8 & 3.5 & 3.5 & {$[33]$} \\
Basaltic andesite & 18 & 11 & $<0.5$ & 2 & 0.32 & 0.5 & {$[34]$} \\
Tholeiitic basalt & 14 & 11 & - & 1.5 & 0.18 & $<0.5$ & {$[34]$} \\
Komatiitic lavas & 5 & 18 & - & 7 & 0.7 & 4 & {$[35]$} \\
MORB & 0.89 & 2.05 & - & 0.11 & 0.03 & - & {$[36]$} \\
Alkali basalt & 0.23 & 0.37 & - & 0.11 & 0.04 & - & {$[36]$} \\
Peridotite xenoliths, S. Africa & 4.3 & 1.84 & 0.93 & 6.54 & 3.67 & - & {$[37]$} \\
Xenoliths, Karelian Craton & 4.84 & 2.28 & 0.79 & 6.58 & 3.75 & - & {$[37]$} \\
\hline
\end{tabular}

*Xenoliths from kimberlites. 
land ophiolite complex (Scotland) [41]; up to $25 \mathrm{ppm}$ in Veria of the northern Greece [35]; average of $10.03 \mathrm{ppm}$ in the Noril'sk region (Russia) [42]; average of $5.418 \mathrm{ppm}$ in the Great Dyke of the South Africa [42]; average of $5.670 \mathrm{ppm}$ for the Bushveld complex of the South Africa [42]; average of $20.699 \mathrm{ppm}$ for the Stillwater area (Montana, USA) [42], etc. What makes the problem even more inexplicable-it is the fact that in numerous cases rocks which usually hosting PGE ore deposits (chromites/chromitites, volcanogenic massive sulfide deposits (VMS)) have very low contents or even practical absence of PGE. For example, PGE in the Uzelginsk VMS deposit (southern Urals, Russia) are found mostly below the detection limits [43]; low values of PGE were discovered in chromites from the Mt. Albert (Quebec, Canada) [44], very low PGE content was identified in some layers of the Bushveld Complex (South Africa) [45]; extremely low PGE content was revealed in the upper portions of the Bushveld Complex [46], etc. All these facts raisesthe questions: "What was the source of PGEs?" and "What was the mechanism of PGEs enrichment in thousands and tens of thousand times?" in the PGE ore deposits.

Table 3 shows comparison of PGE contents in the meteorites of different origin. It is clear from Table 3 that enstatite achondrites, eucrites, Martian meteorites and Lunar meteorites have PGE concentrations pretty close to those in typical Earth's rocks (see Table 2). However, PGE concentrations in CAI inclusions in meteorites, carbonaceous chondrites (CI, CM, CV, CK, $\mathrm{CR}, \mathrm{CH}$ ), chondrules in CR2 chondrites, enstatite chondrites, LL6 ordinary chondrites are 2 to 4 orders of magnitude higher than those in typical Earth's rocks from Table 2. For more information about mean PGE concentrations in different chondrite groups see Table 1 in [47].

Table 3. PGE contents in meteorites of different origin and in different kinds of meteorites and meteorite inclusions.

\begin{tabular}{|c|c|c|c|c|c|c|c|}
\hline \multirow{2}{*}{ Meteorites } & \multicolumn{6}{|c|}{ Concentration, in ppb } & \multirow{2}{*}{ Refe-rences } \\
\hline & $\mathrm{Pt}$ & $\mathrm{Pd}$ & $\mathrm{Rh}$ & $\mathrm{Ru}$ & Ir & Os & \\
\hline enstatite achondrites & $8.8-13.5$ & $9.4-12.2$ & $1.4-1.9$ & $3.3-4.1$ & $2.6-3.2$ & - & {$[48]$} \\
\hline eucrites & - & $0.4-8.5$ & - & - & $0.035-0.36$ & $0.003-0.565$ & {$[49]$} \\
\hline Martian meteorites & $5.40-8.65$ & $4.67-6.05$ & $0.88-1.30$ & $1.60-4.37$ & $0.59-3.65$ & - & {$[50]$} \\
\hline Martian meteorites & $0.16-0.5$ & $0.15-30$ & - & - & $0.057-3.9$ & $0.007-4.4$ & {$[51]$} \\
\hline Lunar meteorite & 9.96 & 2.43 & 0.55 & 1.35 & 0.93 & - & {$[52]$} \\
\hline Lunar meteorite & 12.4 & 3.9 & 0.55 & 1.2 & 0.93 & - & {$[53]$} \\
\hline CAI Inclusions, Allende & $\leq 24,000$ & $\leq 2290$ & $\leq 2840$ & $\leq 20,000$ & $\leq 19,800$ & $\leq 19,000$ & {$[54]$} \\
\hline coarse-grained inclusions & - & - & - & $\leq 16,900$ & $\leq 12,980$ & $\leq 12,100$ & {$[55]$} \\
\hline mean CI Chondrites & 947 & 558 & 139 & 686 & 469 & 493 & {$[23]$} \\
\hline mean $\mathrm{CV}$ chondrites & 1443 & 707 & 209 & 1150 & 758 & 807 & {$[47]$} \\
\hline mean CK chondrites & 1560 & 749 & 213 & 1121 & 772 & 825 & {$[47]$} \\
\hline mean CR chondrites & 1208 & 734 & - & 926 & 622 & 655 & {$[47]$} \\
\hline CR2, bulk for chondrules & $\leq 1570$ & - & - & - & $\leq 930$ & $\leq 950$ & {$[56]$} \\
\hline enstatite chondrites & $598-1080$ & $389-872$ & $92-179$ & $457-897$ & $293-526$ & - & {$[48]$} \\
\hline LL6 ordinary chondrite & 478 & 361 & 81 & 351 & 234 & - & [57] \\
\hline
\end{tabular}


Interestingly, PGEs content of terrestrial rocks and meteorites is usually compared to that of $\mathrm{CI}$ carbonaceous chondrites, because their chemical composition has some similarities with that of the solar photosphere and this is the reason why they viewed in many cases as standards representing composition of solar nebula during its earliest evolution [23] [58] [59]. CI (Ivuna type) group represents the smallest group of carbonaceous chondrites, which in turn making a small fraction $(\sim 5 \%)$ of all chondrites [60]. CI chondrites are very poor in content of chondrules $(<1 \mathrm{vol} \%)$, CAIs $(<1 \mathrm{vol} \%)$, and contain no metal [61]. They contain serpentine-like minerals, which were produced from magnesium-rich olivines and pyroxenes by aqueous alteration [62]. CI carbonaceous chondrites are chemically the most primitive meteorites whose primary mineralogy and petrography were erased by extensive aqueous alteration at $\sim 323-423 \mathrm{~K}$ on their parent body, and which subsequently experienced thermal metamorphism [63].

However, comparison of chemical composition of the Earth's rocks with the different kinds of meteorites led Drake and Righter [64] to conclusion that no primitive material similar to the Earth's mantle is currently represented in any of meteorite collections, and chemical composition of the Earth's mantle is distinct from any extant primitive meteorite type. On the top of that it is well-known fact that the Earth, in contrast to chondrites, passed both melting stage (formation of magma-ocean) and complete differentiation [1] [65] [66]. This means that the chemical composition of CI carbonaceous chondrites should be accepted as composition close to initial composition of solar nebula in regions of formation of terrestrial planets and asteroid belt. It is in complete agreement with analysis of PGEs content in the different kinds of meteorites. Really, high content of PGEs in carbonaceous chondrites could be explained by presence of significant amounts of chondrules and CAIs both of which are rich in PGE (see Table 3). Since CI carbonaceous chondrites are the most primitive and least altered among meteorites, PGEs containing in their chondrules and CAIs escaped redistribution during their evolution that actually is the reason of their high PGEs content. In contrast, achondrites, representing $8 \%$ of meteorites overall [67], are known to pass both stages of melting and differentiation [68]. Their chemical composition and principal minerals (e.g., [69] [70]) are similar to those of magmatic rocks of Earth's crust and upper mantle, and contain PGE amounts (see Table 2 and Table 3) about two orders of magnitude lower than CI carbonaceous chondrites (e.g., [71]) which have about the same level of the PGE content that the Earth's upper mantle rocks. Interestingly, that achondrites do not have chondrules, which most likely were re-worked during melting, differentiation and alteration processes passed by achondrites. Such facts as extremely high Ir content in IIAB, IIIAB, IVA and IVB irons (from single units up to tens of ppm) [72], very low content of Ir (up to 42 and $69 \mathrm{ppb}$ ), and extremely high content of Pd (up to 5.82 and $7.23 \mathrm{ppm}$ ) in IIIB irons and pallasites, respectively [73], as well as high content of Ir (up to 1 - 2 ppm) in some achondrites-Acapulcoites, Lodranites and Winonaites [74], points at importance of influence of re-working, differentiation and processes of alteration to the final PGE content. These 
facts clearly prove that chemical composition of CI carbonaceous chondrites may represent only initial composition of part of solar nebula at about 4.5 - 4.6 $\mathrm{Ga}$, but it cannot characterize present chemical composition of any matter of CI carbonaceous chondrites, because present chemical composition of PGEs in rocks of Earth's crust and upper mantle depends on the last $4.5-4.6 \mathrm{Ga}$ of the Earth evolution.

The formation of PGE compounds is under control of their high density and extremely high melting points (see Table 1). This makes formation of PGE compounds depending on conditions preferable by density (e.g., Pt-Ir and Pt-IrOs alloys), by melting point (e.g., Pt-Pd, Pd-Rh, Pt-Rh and Ir-Os-Ru alloys, and Pt-Pd sulfides and arsenides) and by both density and melting (e.g., Os-Ir alloys). Some researches show that formation of alloys and sulfidation in chondrites are of primary and secondary origin, respectively (e.g., [75] [76]). The same effects can also be used for analysis of PGE formation of sulfides in the Earth. As it was shown in [1] [66] [78], at the time of magma-ocean and its initial solidification almost all sulfur was within the early Earth atmosphere forming sulfur layer much denser than water layer. Thus, until re-distribution of sulfur layer at the end of Early Archean-beginning of Middle Archean, sulfur and its oxides have been interacted only with the Earth surface.

An important point in formation of the PGE compounds in solar nebula is the fact that except Pd all of these compounds are refractory elements, and some of them (Ru, Ir and Os compounds) condense within the temperature range (see Table 1) of formation of CAIs (1473 - $2273 \mathrm{~K}$; [26]), and above temperatures of chondrules formation ( $>1473 \mathrm{~K}$; [26]). Lodders et al. [23] noted that most of PGEs condense as refractory mineral alloys. Such important minerals of CAIs as hibonite and melilite at a total nebular pressure of $10^{-4} \mathrm{MPa}$ first condense at temperatures of $1743 \mathrm{~K}$ and $1628 \mathrm{~K}$, respectively [27] and anorthite condensed at temperature of $1387 \mathrm{~K}$ under pressure of $10^{-5} \mathrm{MPa}$ [58]. This means that PGEs alloys were formed very early during the accretion process along with the formation of CAIs. It should be stated that Pd is the only element from PGEs, which condenses at temperature slightly less than the condensation temperatures of $\mathrm{Fe}$ $(1334 \mathrm{~K})$ and $\mathrm{Ni}(1353 \mathrm{~K})$, and in solar nebula it is concentrated within the Fe-alloys [23].

\section{The "Late Veneer" Hypothesis of PGEs Enrichment}

One of main problems related by numerous researchers to obvious preservation of PGEs in subsurface is the fact that siderophile ("iron-loving") elements heavier than Fe and Ni, and especially such heavy elements as PGEs (see Table 1) and gold, during the accretion and evolution of magma-ocean must have sank to the Earth core (e.g., [79]) and should not be present in the uppermost layers (slabs) of the Earth. At the same time, it is known that the Earth's upper mantle has an overabundance of highly siderophile elements (e.g., PGEs, gold and rhenium) (e.g., [79] [80] [81]) by three orders of magnitude higher than expected from experiments [82]. This fact makes obvious presence of PGEs ore deposits on and 
near the Earth's surface at present even more controversial and enigmatic. To avoid this controversy a new hypothesis was introduced. According to this hypothesis, PGEs, as well as gold and other siderophile elements, numerous ore deposits of which are well known around the world, were added to the Earth not at the time of accretion, but later, after the Earth's core separation (e.g., [79] [83]) known as the "late veneer" (e.g., [83] [84] [85]) and caused by meteorite bombardment during $4.5-3.8 \mathrm{Ga}$ [85] or late heavy bombardment at $3.9-3.8$ $\mathrm{Ga}$ [82], including accretion of asteroids and comets [84]. The authors [84] estimated amount of extraterrestrial bodies struck the Earth after core formation at $(0.7-2.7) \times 10^{22} \mathrm{~kg}$. Taking into account not only masses, but also velocity of cosmic bodies bombarding the Earth, they must produce significant signatures at the Earth's surface and in the subsurface. Geologically and geophysically such signatures (indicators) may be considered (in combination with other factors) as existence of ring structures (RS) of different diameters. Such RS may be identified visually and by the use of special geophysical methodologies oriented to delineation of RS anomalies against the significant noise background (e.g., [86] [87] [88] [89]).

However, there are some problems of the late veneer coordination with geologic data. The heavy bombardment by debris during planetary formation, which lasted from $\sim 4.5$ to $3.8 \mathrm{Ga}$, and especially during the most intense "Late Heavy Bombardment" at about 3.9 - 3.85 Ga [90], could have led to additional heating of Earth's crust and mantle, as well as the formation of local magma-oceans. Such bombardment could have caused heating of upper layers of Earth to the depth of up to $1200 \mathrm{~km}$ to the melting point during the last stage of the Earth's formation [91]. During the Hadean and beginning of the Archean, the Earth's surface temperature was very high and the surface was represented by either a planet-wide ocean or local oceans of magma for a significant time period. Vacquier [92] suggests that events such as runaway accretion, the formation of the Moon, and the impact that tilted Earth's axis of rotation could possibly have created conditions such that the Earth could have melted and solidified three times. All this means that at the end of the "Late Heavy Bombardment" at about 3.85 - 3.9 Ga, the whole Earth could have been covered with either entire or number of local magma oceans up to $1200 \mathrm{~km}$ deep. It is obvious that greater bodies bombarding Earth would release greater amounts of energy and cause more voluminous amounts of melt and deeper local magma-oceans, but those magma-oceans would be formed in places of the most heavy bombardment and late veneer matter would be within those magma-oceans. This makes no difference from initial sinking of extremely dense PGEs within the initial magma-ocean formed as result of the accretion, because delivery of PGEs from the mantle depths of about $1200 \mathrm{~km}$ is not much easier than delivery of PGEs from the core. This means that according to this point of view, PGEs must be presented in the upper mantle and crust only in insignificant amounts.

Another problem is the timing of core separation, which is highly speculative. It is obvious that it would not take place before the end of the Earth's accretion. 
However, Earth's accretion has lasted up to 100 million years [78] and energy released during the accretion was enough to melt the entire Earth. This means that core separation could have taken place only after the accretion finishing. At the same time, at the end of accretion, all the Earth was entirely covered by magma-ocean which could have been existed up to 100 - 200 million years [93] [94] or even longer [95]. This makes any estimation of the core separation timing very speculative one. Moreover, even after the core separation, sinking PGEs within the magma-ocean to depths of about $1000-1200 \mathrm{~km}$ would also move them out of the Earth's subsurface. On other hand, it is obvious that initial deep magma-ocean could have been existed until at least $4.3 \mathrm{Ga}$ and it means that all PGEs from the cosmic objects involved in the heavy bombardment between $\sim 4.5$ $\mathrm{Ga}$ and $4.3 \mathrm{Ga}$ would have sunk to the depths of up to $1000 \mathrm{~km}$ or deeper. But there is a huge possibility that the heavy bombardment would not let magma-ocean to solidify and, as it was shown above, may have lasted until $3.85 \mathrm{Ga}$. In such a case the hypothesis of late veneer addition of siderophile elements to the Earth is lack of evidence.

According to late veneer hypothesis, absolute majority of extremely heavy PGEs must have sunk to the core during the accretion. In such a case, concentrations of PGEs in metal core must be high and maximal. In contrary, in some iron meteorites, which are viewed as analogy of metal core matter, concentrations of PGEs are quite low. For example, content of Ir in some iron meteorites could be as low as: $10 \mathrm{ppb}$ in IIb irons [61]; $10 \mathrm{ppb}$ for IIAB irons [96]; generally between $10 \mathrm{ppb}$ and $100 \mathrm{ppb}$ in IIIB irons [61]; $10 \mathrm{ppb}$ in IIIAB irons [96]; generally between $10 \mathrm{ppb}$ and $100 \mathrm{ppb}$ for IIID irons [61]; 100 ppb in IC irons [61]; $~ 100 \mathrm{ppb}$ in IIIE irons [61]; 100 ppb in IVA irons [96]. All these values are much lower than the mean concentration of Ir in any group of chondrites with minimal content of Ir as $336 \mathrm{ppb}$ in the LL chondrites and maximum content of Ir as $3235 \mathrm{ppb}$ in the CB chondrites [47]. The mean concentration of Ir in most primitive carbonaceous chondrites ranges from $472 \mathrm{ppb}$ for the CI chondrites to $2635 \mathrm{ppb}$ for the CB chondrites [47]; see also Table 3. Ir content in Acapulcoites is within the range of $536-2125$ ppb [74] that is also much higher than was observed in many iron meteorites. Interestingly, the highest concentrations of Ir are: $\sim 1000 \mathrm{ppb}$ for the IIB irons, and $<\sim 1000 \mathrm{ppb}$ for the IC and IAB irons [61]. These facts clearly contradict to the late veneer hypothesis.

On the top of that, the late veneer hypothesis cannot explain many important facts and features. Among them are: presence of non-chondritic platinum-group element ratios (e.g., Pd/Ir) in the Earth's mantle [79]; non-chondritic distribution of the highly siderophile elements found in several types of rock (e.g., sulfides) derived from the Earth's mantle [97]; slightly supra-chondritic Ru/Ir and $\mathrm{Pd} / \mathrm{Ir}$ ratios in the Primitive Upper Mantle [83], etc.

Maier et al. [37] [85] show that the lowest PGEs contents are found in $>3.5 \mathrm{Ga}$ komatiites from the Barberton (South Africa) and Pilbara (Western Australia) terranes.The authors [37] [85] also show that the most of Early Archaean (3.5 $3.2 \mathrm{Ga}$ ) komatiites from the Barberton greenstone belt and the Pilbara craton are 
depleted in PGEs relative to late Archaean ( 2.9 - 2.7 Ga) and younger (2.5 - 2.0 $\mathrm{Ga}$ ) komatiites. Maier et al. [85] proposed that the trends reflect sluggish refertilization of PGEs in the Early and Middle Archean lower mantle with the late veneer, and that the Archean mantle had heterogeneous PGEs content. Maier et al. [85] show that by ca $3.0 \mathrm{Ga}$, the lower mantle appears to have equilibrated with the late veneer. The authors show that PGEs depletion is absent in certain $2.9 \mathrm{Ga}$ komatiites that is linked to equilibration of the lower mantle with the late veneer producing PGE concentration close to modern primitive mantle through gradual homogenization of the meteorite produced PGEs concentration in the entire mantle.

Sankaran [98] analyzed problems related to reflection of trends in the mantle incorporation of meteoritic PGEs by komatiites through some time intervals. $\mathrm{He}$ also indicates severe depletion in PGEs in the oldest (>3.5 Ga) komatiites from the Barberton GSB (South Africa) and Pilbara Craton (Western Australia). The authors [98] shows that the Pt and Pd contents were low ( 2 - $5 \mathrm{ppb})$ in the Barberton GSB and Pilbara Craton, moderate ( $\sim 8 \mathrm{ppb})$ in the Late Archean komatiites from Canada, Zimbabwe, South Australia and Russia, and high ( 8 - 10 $\mathrm{ppb}$ ) in the Mesozoic komatiites of Gorgona Island (Colombia).

Fiorentini et al. [99] point at a systematic linear increase of the PGE contents in komatiite since the oldest age ( $>3.5 \mathrm{Ga})$ in the Late Archaean group $(2.7 \mathrm{Ga})$, regardless of petrogenetic type, as well as linear secular trend of increasing Pt at a given $\mathrm{MgO}$ content, and in $\mathrm{Pt} / \mathrm{Ti}$ from $3.5 \mathrm{Ga}$ to $2.7 \mathrm{Ga}$ across all komatiite types. They state that the Late Archaean komatiites have higher PGE contents as a result of progressive mixing-in of late veneer material over the period between the Late Heavy Bombardment $(4.3-3.9 \mathrm{Ga})$ and $2.7 \mathrm{Ga}$, at which time the mantle had become effectively homogeneous with respect to PGEs.

Maier et al. [37] compared the concentrations of the PGEs and gold in mantle xenoliths from more than 20 kimberlite pipes in the South Africa and Karelian craton (Fennoscandian Shield) and led to the following conclusions: the noble metal content of the primitive mantle cannot be accurately determined using cratonic mantle samples; the data indicate considerable heterogeneity within individual pipes, structural blocks within the individual cratons, and between the cratons; relatively low PGEs contents result from heterogeneous equilibration of the Early- to Mid-Archean mantle with the late veneer; the shallow mantle rocks postdate the onset of crust formation, which is inconsistent with the definition of primitive mantle reservoirs.

Prescher et al. [82] state that the Archean komatiites indicate that the PGEs content of the Earth's mantle increased from about half of their present abundances at $3.5 \mathrm{Ga}$ to their present abundances at $2.9 \mathrm{Ga}$. The authors [82] proposed that this secular increase in PGE content suggests a progressive mixing of the late veneer material into the Earth's mantle and that the whole mantle was relatively well mixed by $2.9 \mathrm{Ga}$.

In contrast, Pattou et al. [79] note that the mantle is heterogeneous in its PGEs content on scales of $\sim 100$ kilometers. 
The idea that PGEs contents in the upper mantle during the Early Archeanwere heterogeneous, but during Late Archean they were homogeneous seems to be ungrounded ones. How is it possible that PGEs contents from Early to Middle Archean were always low, but at Late Archean they everywhere range from moderate to high? Does it mean that significant amounts of PGEs were added to the upper mantle between the Early to Middle Archean and Late Archean? Of course not, because heavy bombardment finished right before the Archean Eon. It means that geological records do not support transformation of PGEs concentration in the upper mantle from heterogeneous during Early-Middle Archean to homogeneous during Late Archean.

Righter et al. [81] analyzed partitioning of palladium (Pd) at high pressure and temperature. They show that the results of experiments at low pressures and temperatures gave very high partition coefficients for the highly siderophile elements (in particular a coefficient for palladium $>10^{4}$ ) that was used for hypothesizing that the high mantle concentrations of the highly siderophile elements and also of volatile elements originated from the addition of chondritic material after core formation as "late veneer". However, results of determination of the partition coefficient at higher pressures and temperatures that approximate the early Earth conditions gave much lower partition coefficients for the palladium $(\sim 480)$ consistent with an equilibration scenario [81]. Based on this finding, the authors [81] led to the conclusion that there is no need for a late veneer to explain the terrestrial-mantle palladium content.

Tagle and Claeys [100] reported contents of PGEs in the Popigai (Siberia, Russia) impact melt caused by the Late Eocene comet or asteroid showers initiated from the Oort Cloud. Since comets are believed to be primitive bodies with a composition like that of carbonaceous chondrites [100], it should be expected that concentrations of PGEs in comets are high. However, in contrast average contents of PGEs are: $1.75 \mathrm{ppb}$ of $\mathrm{Pd}, 2.58 \mathrm{ppb}$ of $\mathrm{Pt}, 1.77 \mathrm{ppb}$ of $\mathrm{Ru}, 0.42$ $\mathrm{ppb}$ of Rh and $0.96 \mathrm{ppb}$ of Ir [100]. These values are very close to PGEs content in the Earth's crust and some magmatic rocks and even much lower than the PGEs content in several magmatic rocks (see Table 1).

All these facts do not support the late veneer hypothesis of the late PGEs addition to the Earth's upper layers (slabs).

Another case is the Younger Dryas impact hypothesis or Clovis comet hypothesis at about 12,900 BP [e.g., [101] [102]]. Analysis of data from 12 of 50 sites of the impact shows that Ir concentration in bulk sediments is within the range from $<0.5$ to $3.8 \mathrm{ppb}$, and Ir concentration in magnetic fraction is within the range from $<1$ to $<2 \mathrm{ppb}$ in five sites and in four sites it consists of $15,24,51$ and $117 \mathrm{ppb}$. Upon retesting aliquots of high-Ir samples, five from nine sites were confirmed, but Ir abundances were below the detection level in four retests. The Ir concentration values in bulk sediments are of same range of magnitude as in most terrestrial rocks (see Table 2), as well as in achondrites, Martian and Lunar meteorites (see Table 3), but they are more than on 2 orders of magnitude lower than the Ir concentration in the CI carbonaceous chondrites. On other hand, as 
it is clear from Table 1 [101] that there is no any correlation between $\mathrm{Ir}, \mathrm{Ni}, \mathrm{Fe}$ and $\mathrm{Ti}$, which is very unusual for siderophile elements [101] [102]. It is known that Ir peaks were found at major geologic boundary layers with no confirmed impacts, and at least some of those Ir concentrations may have resulted from volcanism [101]. This means that any slight PGEs enrichment could be caused by volcanism rather than be delivered by meteorites. Moreover, Paquay et al. [103] state that they did not found any osmium or iridium anomalies in the Younger Dryas sediments. All these facts also not support the late veneer hypothesis, because no really high concentrations of PGEs were detected, how it should be expected from the carbonaceous chondrites and comets according the late veneer hypothesis.

In both cases of the Popigai and Younger Dryas impact structures we should expect that delivered PGEs would stay on place, because there was no magma-ocean for them to sink to deep levels or some other processes, that would make them disappear. This means that absence of any significant PGEs contents in such cases indicates against the late veneer hypothesis, because it is difficult to expect that all carbonaceous chondrites and comets involved to the heavy bombardment before $\sim 3.8 \mathrm{Ga}$ (which did not leave a trace) were extremely rich in PGEs, but later impacts of carbonaceous chondrites and comets did leave any traces of significant PGEs contents delivered to the Earth surface.

All above-mentioned means that there must have been other mechanisms of preservation and concentration of PGEs and PGMs in the Earth's upper slabs.

\section{Initial Concentration of PGEs and PGMs during the Early Earth Evolution}

It is known that all matter on the Earth originated from the solar nebula by infalling of the nebular material onto the evolving planet during its accretion. This means that in order to accumulate significant amounts of PGEs and PGMs near the Earth's surface, there must have been certain mechanisms of their concentration in near-surface layers, their trapping, and preservation.

Research shows that PGEs are mostly presented in rocks as inclusions of native metals, alloys, sulfides, arsenides, telurides, etc. From the early stages of accretion on the Earth, a magma-ocean with a depth of up to $1000 \mathrm{~km}$ has been formed and existed for millions or even hundreds of millions of years [e.g., [77]]. The magma-ocean was stratified by density and iron content, with a felsic-intermediate-mafic-ultramafic sequence of layers from the top to bottom [77]. If the magma-ocean has existed for a long-time period, there is also the possibility of magma fractionation by the main rock-forming minerals, along with the formation of the "forsterite layer" [1] [78] at a certain depth, plagioclase layer at the top, etc. A plagioclase layer is known to have been formed within the Lunar magma-ocean, representing the oldest plagioclase or anorthositic Lunar crust [104]. The presence of enormous amounts of anorthosites in the Earth also indicates the possibility of such a layer formation within the Earth's magmaocean. In addition to that, the presence of massive (1000-s to $10,000-\mathrm{s} \cdot \mathrm{km}^{3}$ ) 
anorthosites [105] of the Mid-Proterozoic suggests the earliest Earth crust had an anorthositic composition, since the formation of magma chambers capable of otherwise collecting such enormous quantities of anorthosites within the crust would be extremely unlikely and these volumes of anorthosites could have been formed within the magma-ocean only. It is also conceivable that both the differentiation of magmatic rocks and their fractionation by main rock-forming minerals evolved in parallel, depending on the thermodynamic conditions and period of the magma-ocean's existence in different regions of the Earth (e.g., [78]).

Formation of the lithosphere has started with formation of the "forsterite layer" [1] [78] [106] at depths of $\sim 70-100 \mathrm{~km}$. Even though forsterite has the highest melting point among silicates $(2163 \mathrm{~K}$ at $0.1 \mathrm{MPa}$ [107] and $2307 \mathrm{~K}$ at 3 $\mathrm{GPa}$ [108]), its density is very low in both molten $\left(2970 \mathrm{~kg} / \mathrm{m}^{3}\right.$ at $2163 \mathrm{~K}$ [109]) and solid $\left(3222 \mathrm{~kg} / \mathrm{m}^{3}\right)$ states and it would prevent forsterite from sinking within any melt with even small content of iron (e.g., Table 4 and Table 5).

This means that from the time of formation of the "forsterite layer", heavy compounds including refractory mineral alloys had no chance to sink below the layer (slab). They were trapped above the layer and their enrichment was proportional to time from formation of the layer to at least starting of solidification of the magma-ocean upper section. On other hand, geothermal gradient within the molten planet is the adiabatic geothermal gradient that is extremely small (e.g., [78] [120] [121]). The estimated value of the adiabatic geothermal gradient is as low as $0.5 \mathrm{~K} / \mathrm{km}$ [120] and $0.3 \mathrm{~K} / \mathrm{km}$ [121]. This means that to keep temperature as high as $\sim 2307 \mathrm{~K}$ at depths corresponding to pressure $\sim 3 \mathrm{GPa}$ the surface

Table 4. Density of molten forsterite, fayalite and olivine Fo93 (modified after [78]).

\begin{tabular}{cccc}
\hline Mineral & Temperature, K & $\begin{array}{c}\text { Density, } \\
\mathrm{kg} / \mathrm{m}^{3}\end{array}$ & Reference \\
\hline Forsterite & 2163 & 2970 & {$[109]$} \\
Fayalite & 1573 & 3757 & {$[110]$} \\
& 1673 & 3725 & {$[110]$} \\
3000 & 3529 & {$[111]^{*}$} \\
2163 & 3810 & {$[112]$} \\
1773 & 3747 & {$[113]$} \\
1573 & 3750 & {$[73]$} \\
1673 & 3766 & {$[73]$} \\
1773 & 3688 & {$[114]$} \\
1300 & $\sim 3875$ & {$[114]$} \\
1500 & $\sim 3861$ & {$[114]$} \\
1600 & 3850 & {$[115]$} \\
& 1973 & 3593 & {$[115]$} \\
2023 & 3586 & {$[115]$} \\
& 2073 & 3587 & {$[115]$} \\
2123 & 3560 & {$[116]$} \\
\hline & - & 2865 & \\
\hline
\end{tabular}

${ }^{*}$ Calculated using data of [111]. 
Table 5. Density of some ultramafic rocks and chromites.

\begin{tabular}{ccc}
\hline Rock & Density, $\mathrm{kg} / \mathrm{m}^{3}$ & Reference \\
\hline Cobalt chromite, $\mathrm{CoCr}_{2} \mathrm{O}_{4}$ & 5140 & {$[22]$} \\
Copper chromite, $\mathrm{CuCr}_{2} \mathrm{O}_{4}$ & 5400 & {$[22]$} \\
Iron chromite, $\mathrm{FeCr}_{2} \mathrm{O}_{4}$ & 5000 & {$[22]$} \\
$\mathrm{Zinc}$ chromite, $\mathrm{ZnCr}_{2} \mathrm{O}_{4}$ & 5290 & {$[22]$} \\
Peridotite & 3230 & {$[117]$} \\
Dunite & 3280 & {$[117]$} \\
Dunite & 3160 & {$[118]$} \\
Dunite xenoliths from basalts & $3244-3326$ & {$[119]$} \\
\hline
\end{tabular}

temperature of Earth at the time of accretion and formation of magma-ocean must have been in excess of $2260 \mathrm{~K}$ which is much higher than temperature of the magma-ocean start solidification at surface temperature $\sim 1300$ - $1500 \mathrm{~K}$ (e.g., [1] [77]). Such a high temperature of the Earth's surface was unbearable to keep for a long time. This means that solidification of forsterite with formation of the "forsterite layer" could have started at very early stage of the Earth formation, probably during the time of its accretion. It was shown earlier [77] [78] that formation of the "forsterite layer" could have started from solid forsterite, if temperature within the upper layers of forming Earth was not high enough to melt forsterite [77] [78]. All this indicates that formation of solid layer at relatively shallow depth within the forming Earth could have started during the accretion or at the earliest stages of the magma-ocean evolution. This means that such solid layer could have formed a barrier for all heavy species, including siderophile elements and, what important here, PGEs and PGMs, which would prevent them from sinking to the depths of core or lower mantle. This fact could be a cause of preservation of PGEs and other siderophile elements at shallow depths (above $70-100 \mathrm{~km}$ ) within the forming Earth. Among next to the "forsterite layer" in the upper mantle part of the forming early Earth's lithosphere according melting points at $0.1 \mathrm{MPa}$ solidification process pass: chromites of different composition with the melting points within a range of temperatures from $1908 \mathrm{~K}$ for incongruent melting [122] to 2473 - $2673 \mathrm{~K}$ [123]; dunite with the melting point of $2073 \mathrm{~K}$ and olivine composition of $\mathrm{Fo}_{90} \mathrm{Fa}_{10}$ [124]; harzburgites with the melting point of $1633-1773 \mathrm{~K}$ at pressure of $1.0-1.5 \mathrm{GPa}$ [125]; and lherzolites with the melting point of $1543-1693 \mathrm{~K}$ at pressure of $1.0-1.5$ GPa [125]. These data show that some chromites have melting point the same or close to that of dunites, even though most of chromites have much higher melting points than dunites, but melting points of chromites much higher than that of harzburgites and lherzolites with a significant gap. This testifies that some of chromites were solidifying with dunites at the same time or some time earlier. It is clear that significant amount of chromites (Table 6) has melting points greater than that of forsterite and it indicates that those chromites, taking into account their high density $\left(5000-5400 \mathrm{~kg} / \mathrm{m}^{3}\right)$, were mostly plunged to the great depths within the upper mantle before the "forsterite layer" formation. 
Table 6. Melting point of some ultramafic rocks and chromites.

\begin{tabular}{ccc}
\hline Rock & Melting point, K & Reference \\
\hline dunite & 2023 & {$[126]$} \\
dunite & 2073 & {$[124]$} \\
harzburgite (at $1 \mathrm{GPa}$ ) & $1633-1743$ & {$[125]$} \\
harzburgite (at 1.5 GPa) & $1693-1773$ & {$[125]$} \\
harzburgite (at $>5 \mathrm{GPa})$ & $1723-1873$ & {$[127]$} \\
lherzolite (at 1 GPa) & $1543-1633$ & {$[125]$} \\
lherzolite (at 1.5 GPa) & $1633-1693$ & {$[125]$} \\
peridotite (at 4.5 - 5.0 GPa) & 1723 & {$[127]$} \\
chromites (different) & $2123-2473$ & {$[128]$} \\
chromite (monocalcium) & 2443 & {$[129]$} \\
chromites (different) & $2473-2673$ & {$[123]$} \\
chromites (Lanthanum) & $\geq 2273$ & {$[130]$} \\
chromite (incongruent melting) & 1908 & {$[122]$} \\
(Fe, $\mathrm{Mg}_{\text {) }}$ Cr $\mathrm{O}_{4}$ (spinel) & $\sim 1873$ & {$[131]$} \\
$\mathrm{MgCr}_{2} \mathrm{O}_{4}$ & 2623 & {$[132]$} \\
chromite & 2453 & {$[133]$} \\
chromites (Slag liquidus) & $\sim 1873-2273$ & {$[134]$} \\
$\mathrm{MgCr}_{2} \mathrm{O}_{4}$ (sintering) & $\sim 2023$ & {$[132]$} \\
$\mathrm{NiCr}_{2} \mathrm{O}_{4}$ (sintering) & $\sim 2096$ & {$[136]$} \\
$\mathrm{MnCr}_{2} \mathrm{O}_{4}$ (sintering) &
\end{tabular}

However, some chromites, which did not sink to the great depths by some reason or appeared within the magma-ocean along with other matter of continuing infalling of cosmic objects, would be blocked from sinking by the "forsterite layer". It is in agreement with the fact of presence of significant amounts of PGEs associated with chromites/chromitites usually enveloped by dunites found in regions of obduction, formation of ophiolites and serpentinites. For example, PGEs rich chromitite occurs as centimetric veins, pods and schlieren enveloped by dunite at the Middle Arm Brook, Central Advocate ophiolite complex (Baie Verte Peninsula, Newfoundland, Canada) [137]. Analysis of olivine inclusions in the chromites/chromitites found in regions of ophiolites formation demonstrates that those inclusions contain olivines with forsterite content up to $\mathrm{Fo}_{98-99}$ in ophiolites: Kempirsai, Kazakhstan [138]; Shangla, Pakistan [139]; Jungar, China [140]; Egypt [141]; and generally with forsterite content $>\mathrm{Fo}_{92}$. This testifies that at the time of formation of chromites in different regions, olivine inclusions within chromites/chromitites were already solidified and it places constraint on temperature of solidification of those chromites.

Estimations of temperature solidification of chromites found in mentioned ophiolites gave temperatures of $<2108-2156 \mathrm{~K}$. At the same time, the fact of enveloping chromites by dunites shows that such association was formed either when dunite was at the early stages of its solidification, or dunitic magmas rising from below the "forsterite layer" were enveloping by solid chromites above the 
layer. This is in agreement with a conclusion made by Pushkarev et al. [142] that chromitites in the Ural-Alaskan type mafic-ultramafic complexes start to form when dunite was almost solid at the end of plastic deformation process. Such a model of formation of chromite-dunite complexes is supported by the fact that content of forsterite in dunites is always lower than in the corresponding chromites. For example, within the Alaskan-type Tulameen complex (British Columbia) olivine inclusions in chromites contain olivines with $\mathrm{Fo}_{92}-\mathrm{Fo}_{95}$ and olivines in dunites have $\mathrm{Fo}_{88}-\mathrm{Fo}_{91}$ [143]; in the Logar Ophiolite Complex (Afghanistan) olivines in chromites and dunites contain $\mathrm{Fo}_{94}-\mathrm{Fo}_{96}$ and $<\mathrm{Fo}_{92}-\mathrm{Fo}_{94}$, respectively [144]; in the Mawat ophiolite (Iraq) olivines in chromites and dunites contain $\mathrm{Fo}_{91}-\mathrm{Fo}_{95}$ and $\mathrm{Fo}_{89}-\mathrm{Fo}_{92}$, respectively [145]; in Jungar ophiolite (China) olivines in chromites and dunites contain $\mathrm{Fo}_{96.1}-\mathrm{Fo}_{98.3}$ and $\mathrm{Fo}_{90}-\mathrm{Fo}_{94}$, respectively [140]. Interestingly, olivine composition in chromitites and dunites in PGE deposits of the Singhbhum Craton (Indian Shield) contain $\mathrm{Fo}_{96}-\mathrm{Fo}_{98}$ and $\mathrm{Fo}_{92}-\mathrm{Fo}_{95}$, respectively. The temperatures of solidification of dunites in the referencing regions range between $2081 \mathrm{~K}$ (for $\mathrm{Fo}_{88}$ ) and $2129 \mathrm{~K}$ (for $\mathrm{Fo}_{95}$ ). All these temperatures are obtained for the pressure of $0.1 \mathrm{MPa}$ and at different depths they were higher depending on the real pressure, but it is clear that a sequence of solidification was forsterite-chromite-dunite with small differences in temperature that makes timing of their formation pretty close on geologic time scale. Obviously, solid "forsterite layer" has trapped chromites with PGEs above itself, and then solid chromites with PGEs were enveloped by solidifying dunite. However, it is known that in numerous cases the PGE-rich chromites are enveloped by dunites that indicates chromites were already solid while dunites still be partly molten at the time of formation of such complexes. If dunites were molten, completely denser PGE-rich chromites would sink through them. At the same time, it means that forsterite and olivine with Fo content $\geq 94 \%$ - 95\% were already solid and solid "forsterite layer" was already in the place preventing chromite and PGEs from sinking within magma-ocean. However, presence in chromites olivines with Fo content $\geq 94 \%$ - 95\% means that solidification of those chromites took place when inclusions of Fo-high olivines were already solid. It places some constraints on thermal conditions of formation of PGE-rich chromites, as well as constraints on formation of chromite-containing dunite complexes. Such a model of formation of chromite-dunite complexes is supported by the fact that content of forsterite in dunites always lower than it is in the corresponding chromites.

Solidification of the crustal part of lithosphere most likely started with the solidification of quartz (christobalite), leucite, tridymite, anorthite and $\beta$-quartz having melting points $1996 \mathrm{~K}, 1958 \mathrm{~K}, 1943 \mathrm{~K}, 1830 \mathrm{~K}$ and $1823 \mathrm{~K}$, respectively. Since both high-temperature quartz and leucite have lowest densities among the main rock-forming minerals, within magma-ocean they would most likely present within the topmost layers of the magma-ocean and they were first to solidify within the forming crust. It should be stated that any new solid layer forming during the early Earth evolution would form a barrier for heavy species to sink 
through the molten upper layers of forming Earth to its deep levels (e.g., crust, lower mantle). Any such layer would be formed similarly with the "forsterite layer" under strict control of the density of layer composing rocks at corresponding depths.

For characteristics of pristine lithosphere composition, a simplified model of the composition was compiled (Table 7).

All the afore-mentioned shows that there were mechanisms available for trapping PGEs and other siderophile elements at different levels of the forming Earth above $70-100 \mathrm{~km}$ depths from the early Earth evolution stages as old as the accretion process and during the evolution and solidification of magma-ocean.

Since the magma-ocean was represented by viscous liquid magmas, entities infalling from the accretion disc were also separated by density within it. Such highly dense metals as PGEs would certainly sink in the magma. Viscosity of magmas in the magma-ocean was strongly depend on the magma composition and its temperature, and viscosity controlled processes of differentiation of matter within the magma-ocean and terminal velocity of sinking species continuing to infall into the magma-ocean from the cosmic space. The importance of the thermal characteristics for rate of differentiation of matter is related to the fact that increase of temperature leads to significant decrease of viscosity of molten rocks [e.g., [146]] that would speed up the differentiation at high temperature conditions and slow down the differentiation on cooling or at low temperature conditions. It would work for sinking both liquids and solids within less dense liquid. For sinking solids, terminal velocity of an object sinking into viscous liquid depends on its size, density, viscosity of liquid, and it can be described by the Stokes equation (e.g., [147]):

$$
v=\frac{2 r^{2} g\left(\sigma-\sigma_{M}\right)}{9 \eta},
$$

where $v$ is the terminal velocity of a sphere with radius $r, \sigma$ is the density of a

Table 7. Simplified model of pristine lithosphere formed during solidification of magma-ocean.

\begin{tabular}{cccc}
\hline $\begin{array}{c}\text { Layer } \\
\text { number }\end{array}$ & $\begin{array}{c}\text { Layer density, } \\
\mathrm{kg} / \mathrm{m}^{3}\end{array}$ & $\begin{array}{c}\text { Melting point (in K) at } \\
0.1 \mathrm{MPa},\end{array}$ & Layer composition \\
\hline 1 & $<2500$ & $1823-1986$ & $\mathrm{SiO}_{2}$-rich layer \\
2 & $2500-2600$ & $T_{\mathrm{m}}>1391-1423$ & $\mathrm{SiO}_{2}+\mathrm{K}-\mathrm{Fsp}+\mathrm{Ab}$-rich \pm Olg \\
4 & $2620-2660$ & $1400<\mathrm{T}_{\mathrm{m}}<1555$ & Olg + Qtz \pm And-rich \\
6 & $2660-2690$ & $1460<\mathrm{T}_{\mathrm{m}}<1645$ & And \pm Lab-rich \\
9 & $2690-2720$ & $1555<\mathrm{T}_{\mathrm{m}}<1763$ & Lab \pm Byt-rich \\
11 & $2720-2760$ & $1645<\mathrm{T}_{\mathrm{m}}<1830$ & Byt \pm An-rich \\
13 & $2760-2900$ & 1830 & An-rich (Anorthite layer) \\
15 & $3160-3280+$ & $2023-2073+$ & Dun \pm Chr \\
16 & 3222 & 2163 & Fo-rich (forsterite layer)
\end{tabular}

$\mathrm{SiO}_{2}$, amorphous silica; K-Fsp, potassium feldspar; Ab, albite; Olg, oligoclase; Qtz, quartz; and, andesine; Lab, labradorite; Byt, bytownite; An, anorthite; Dun, dunite; Chr, chromite; Fo, forsterite. 
sphere, $g$ is the gravity acceleration, $\eta$ is the viscosity of the medium, and $\sigma_{M}$ is the density of the medium.

It is clear from Equation (1) that terminal velocity of the sinking species strongly relates to the radius (proportional to $r^{2}$ ) of species and it would be high for the species with the large radius and it would be low for the species with the small radius. The terminal velocity is inversely proportional to viscosity $(\eta)$ and proportional to density difference $\left(\sigma-\sigma_{M}\right)$ between the sinking species $(\sigma)$ and the melt $\left(\sigma_{M}\right)$. This means that the terminal velocity for PGEs by density would be highest for osmium (Os) and lowest for palladium (Pd).

Performed analysis shows that viscosity of rocks (depending on temperature and type of melt) changes from $0.01-10 \mathrm{~Pa} \cdot \mathrm{s}$ for komatiites to $\sim 10^{11} \mathrm{~Pa} \cdot \mathrm{s}$ for anhydrous granite and dacite. Forsterite has viscosity valuewhich is very close to that of komatiites.

It is well known that addition of water to rocks and minerals significantly reduces their viscosity [e.g., [148] [149]], but before formation of the water-ocean (at about $3.42-3.26 \mathrm{Ga}$ ) the rocks composingthe Earth crust and mantle were essentially dry. Results of research on viscosity of melts testify that viscosity is always significantly increasing with increase of silica content along the join $\mathrm{SiO}_{2}$ $\mathrm{NaAlSiO}_{4}$ [150] and diopside-albite binary system [151]. This means that the silica-rich felsic rocks would have highest viscosity among the typical magmatic rocks.

The lowest densities in both solid and molten caused forming high temperature silica polymorphs (following in increasing order of density by $\mathrm{SiO}_{2}+\mathrm{Al}_{2} \mathrm{O}_{3}$ binary compounds $\left(\mathrm{Al}_{2} \mathrm{O}_{3}\right.$ content less than $\left.\left.22.4 \mathrm{wt} . \%\right)\right)$ : K-feldspars, albite, felsic magmatic rocks, intermediate magmatic rocks, basic magmatic rocks and ultramafic magmatic rocks. This means that topmost layers within the magma-ocean were represented by quartz and/or quartz-rich compounds, K-feldspars and/or $\mathrm{K}$-feldspar-rich compounds and albite and/or albite-rich compounds, and so on. At the same time, increasingthe period of magma-ocean evolution ledto closeness of those layers' content by pure mineral composition due to fractionation (e.g., Table 7). It is also obvious that on contacts of the layers' such binary system as quartz-K-feldspars, K-feldspars-albite, etc., could have been developing.

Comparison of above data with data shown in Table 7 displays that within the pristine lithosphere formed during solidification of magma-ocean silica, Kfeldspar, and different plagioclase (different contents of albite $(\mathrm{Ab})$ and anorthite (An)) layers would form main crustal layers positioned according to their density and solidified permitting their melting points. Depending on the plagioclase composition, the plagioclase layer was characterized by a viscosity within the range of $4.5 \mathrm{~Pa}$ s for anorthite $(\mathrm{An})$ to $10^{7} \mathrm{~Pa}$ s for albite $(\mathrm{Ab})$ at their liquidus temperatures [152] [153]; its melting point would have been within the range of $1391 \mathrm{~K}$ for $\mathrm{Ab}$ to $1830 \mathrm{~K}$ for $\mathrm{An}$ [154]; and density within the range of $2620 \mathrm{~kg} / \mathrm{m}^{3}$ for $\mathrm{Ab}$ to $2760 \mathrm{~kg} / \mathrm{m}^{3}$ for An [153]. For instance, for the Earth anorthosites with a usual composition of $40 \%-80 \%$ of An [155], the viscosity is in the range of $5.5 \times 10^{3}$ Pas (for $\left.\mathrm{An}_{40}\right)$ to $1.7 \times 10^{2}$ Pas $\left(\right.$ for $\left.\mathrm{An}_{80}\right)$ [153] at liquidus 
temperatures, and the melting point is in the range [154] of $1567 \mathrm{~K}$ (for $\mathrm{An}_{40}$ ) to $1742 \mathrm{~K}$ (for $\mathrm{An}_{80}$ ). For Archean anorthosites with An content of $90 \%$ [155], the melting point of the plagioclase is $1786 \mathrm{~K}$. Viscosity of plagioclase melts at liquidus temperatures calculated using data of [152] [153] is about: $4.5-8.5 \mathrm{~Pa} \mathrm{~s}$ for anorthite $\left(\mathrm{An}_{90-100}\right) ; 8.5$ - $35 \mathrm{~Pa}$ s for bytownite $\left(\mathrm{An}_{70-90}\right) ; 35$ - $200 \mathrm{~Pa}$ s for labradorite $\left(\mathrm{An}_{50-70}\right) ; 2 \times 10^{2}-2 \times 10^{3} \mathrm{~Pa} \cdot \mathrm{s}$ for andesine $\left(\mathrm{An}_{30-50}\right) ; 2 \times 10^{3}-10^{5} \mathrm{~Pa} \cdot \mathrm{s}$ for oligoclase $\left(\mathrm{An}_{10-30}\right) ; 10^{5}-10^{7} \mathrm{~Pa}$ s for albite $\left(\mathrm{An}_{0-10}\right)$. Data of Shaw [156] indicate that even at high temperatures viscosity of albite is high: $\sim 10^{4.2} \mathrm{~Pa} \cdot \mathrm{s}$ at $\sim 1667$ $\mathrm{K}, \sim 10^{4.25} \mathrm{~Pa} \cdot \mathrm{s}$ at $\sim 1587 \mathrm{~K}$, and $\sim 10^{5} \mathrm{~Pa} \cdot \mathrm{s}$ at $\sim 1537 \mathrm{~K}$. At the same time, viscosity of K-feldspar is much higher than viscosity of albite at the same temperatures [156]. This means that albite and K-feldspar rich rocks are suitable for trapping of heavy microscopic entities settling within the melt.

One of the most important parameters, determining viscosity, is the rate of cooling of the magma-ocean layers. The liquidus temperatures of plagioclase are very high for some of its compositions, and the difference between liquidus and solidus temperatures for its intermediate compositions like labradorite and andesine can reach $\sim 200 \mathrm{~K}$ [154]. This means that if the temperature of the cooling layer dropped below its liquidus, the plagioclase could still be in viscous liquid condition, though its viscosity would increase dramatically. On top of that, Öhman and Kring [157] show that depending on the content of clasts in the melt, the viscosity of norite within the temperature range of $1500-1973 \mathrm{~K}$, can increase by an order of up to $2-2.5$ for $30 \%$ and $3.5-4$ for $50 \%$ clasts content. For example, viscosity of norites with $50 \%$ clasts is: $\sim 10^{4.9}-10^{7.5} \mathrm{~Pa} \cdot \mathrm{s}$ at $\sim 1500 \mathrm{~K}$, $10^{3.1}-10^{5} \mathrm{~Pa} \cdot \mathrm{s}$ at $\sim 1600 \mathrm{~K}$, and $\sim 10^{1.5}-10^{2} \mathrm{~Pa} \cdot \mathrm{s}$ at $1973 \mathrm{~K}$ [157]. This means that the infalling of objects composed of minerals of refractory elements and other compounds with high melting points would create conditions of significantly increased viscosity within the magma-ocean, depending on the clasts content of the original molten layer.

Hiemstra [158] employed the Stokes equation (Equation (1)) to explain the settling of PGMs during the formation of PGE deposits in the Merensky and UG-2 reefs of the Bushveld Complex. Pilchin [159] utilized this equation to clarify the exhumation of peridotites and metamorphic blocks during the serpentinization process. Matveev and Ballhaus [160] also show that the large-scale concentration of chromite in ore bodies is driven by density contrasts between the chromite-laden fluid pools and silicate melt following from the Stokes law. Interestingly that Hiemstra [158] simply dismissed the settling of small grains of PGMs on their own, and stated that larger chromite grains carried them down. However, in reality small grains would have a much slower terminal velocity and it would take a much longer time for them to settle, which represent the perfect conditions to trap them in highly viscous melts.

Even though PGEs and PGMs mineralization in many cases are associated with chromites/chromitites, there is evidence that the PGMs are rarely enclosed by chromite ([161] [162] [163]). Page et al. [163] investigated presence of IPGEs (Ir-group) in natural chromite and show that all these elements are below the 
detection level, except for chromites from komatiites which contain in average $268 \pm 26 \mathrm{ppb}$ of $\mathrm{Ru}$. The authors [163] have shown that all of the plutonic chromites and almost all chromites from the lavas do not contain any IPGE in solid solution, at least at the resolution of the detection limits; on average IPGE are not controlled by crustal plutonic chromite, mantle chromite, chromite in boninites, or chromite in MORB. It was most likely caused by the fact that all chromites and PGEs were already solid at the time of magma formation or that some chromites could be formed from melt at temperatures about or below melting point of komatiites. Obviously, this is the reason why chromite can contain solid inclusions of IPGEs, but absence of IPGEs in regular chromites point at the fact that temperature within the magma ocean was not high enough for melting all chromites from the beginning or it was high only for a short period of time. On other hand, high content of PGEs in chromitites and low content of IPGEs in chromites mean that main concentration of PGEs came from plagioclase part of chromitites, from remnants of magma-ocean having high content of anorthite.

Analysis of data on the sizes of grains and inclusions of PGEs and PGMs from a vast amount of publications shows that their sizes are generally $<10 \mu \mathrm{m}$ for PGE alloys and $<15 \mu \mathrm{m}$ for PGMs. There are also numerous reports about the size of PGE-alloys and Au inclusions being less than 0.1 - $1 \mu \mathrm{m}$ (e.g., [164] [165] [166]), and even "invisible" gold found in pyritic $\mathrm{Cu}-\mathrm{Zn}$ ore from Uzelginsk (southern Urals, Russia) [43]. Microinclusions of noble metals with size $<0.1 \mu \mathrm{m}$ were found within the Merensky Reef (Bushveld Complex) [164]. Submicroscopic gold in coarse-grained pyrite of the main mineralization stage (mean concentrations up to $1.01 \mathrm{ppm}$ in the Pindos ores and $0.22 \mathrm{ppm}$ in the Mirdita ores) was discovered in ophiolites of the Balkan Peninsula [165].

The terminal velocities of settling PGEs for grain sizes with a radius of $1 \mu \mathrm{m}$, $10 \mu \mathrm{m}$ and $100 \mu \mathrm{m}$ within the different kinds of magmatic rocks are presented in Table 8. Analysis of these data indicates that the lowest and highest values for terminal velocity relate to $\mathrm{Pd}$ and Os, respectively.

It is clear from Table 8 that the terminal velocity of even micro-grains of PGMs sinking in mafic and ultramafic magmas is very high and would cause them to quickly descend to deep levels within the magma-ocean during the first few millions of years of its existence, and only submicron-sized grains had a chance of staying in the magma at the time it solidified within the magma-ocean. In contrast, grains measuring $\leq 10 \mu \mathrm{m}$ sink much slower in andesite magma and would be mostly preserved within such a layer. The terminal velocity in felsic magmas is very slow and grains with sizes $\leq 10 \mu \mathrm{m}$ would almost certainly be preserved within the magma; even grains measuring up to $100 \mu \mathrm{m}$ were in some cases able to remain. Depending on the viscosity and span of the existence of the magma-ocean, grains $\geq 100 \mu \mathrm{m}$ in size could have been preserved only in certain cases within felsic magmas. This is in agreement with the fact that within the Ural-Alaskan type of PGE deposits, size of PGE grains and microinclusions (e.g., 0.5 - $2.0 \mathrm{~mm}$ in Yukon; [171]), is much greater than in ALMI PGE deposits, because huge PGE grains sank within the magma-ocean to greater depths, and later 
Table 8. Terminal velocity of PGE inclusions settling in different magma types.

\begin{tabular}{|c|c|c|c|c|c|}
\hline \multirow{2}{*}{ Magma type } & \multirow{2}{*}{$\begin{array}{l}\text { Temperature of } \\
\text { magma, } \mathrm{K}\end{array}$} & \multirow{2}{*}{$\begin{array}{l}\text { Viscosity of } \\
\text { melt, Pa s }\end{array}$} & \multicolumn{3}{|c|}{ Terminal velocity ( $\mathrm{m} /$ year) of inclusions with radius of } \\
\hline & & & $1 \mu \mathrm{m}$ & $10 \mu \mathrm{m}$ & $100 \mu \mathrm{m}$ \\
\hline Basalt & 1473 & $10^{1}-10^{2}$ & $(0.64-13.7) \times 10^{-3}$ & $(0.64-13.7) \times 10^{-1}$ & $6.4-137$ \\
\hline Andesite & 1473 & $10^{3}-10^{4}$ & $(0.65-13.8) \times 10^{-5}$ & $(0.65-13.8) \times 10^{-3}$ & $(0.65-13.8) \times 10^{-1}$ \\
\hline Rhyolite & 1473 & $10^{5}-10^{6}$ & $(0.66-13.8) \times 10^{-7}$ & $(0.66-13.8) \times 10^{-5}$ & $(0.66-13.8) \times 10^{-3}$ \\
\hline Komatiite & $1873-2073$ & $0.1-10$ & $(0.64-13.6) \times 10^{-1}$ & $6.4-136$ & $(0.64-13.6) \times 10^{3}$ \\
\hline Forsterite + enstatite & $2043-2523$ & $0.02-0.13$ & $0.031-1.04$ & $(0.031-1.04) \times 10^{2}$ & $(0.031-1.04) \times 10^{4}$ \\
\hline Forsterite & 2600 & $0.01-0.1$ & $0.062-1.35$ & $(0.062-1.35) \times 10^{2}$ & $(0.062-1.35) \times 10^{4}$ \\
\hline Molten peridotite & near liquidus & 0.1 & $0.62-1.35$ & $(0.64-1.35) \times 10^{2}$ & $(0.64-1.35) \times 10^{4}$ \\
\hline Granite, anhydrous & 1073 & $\sim 10^{11}$ & $(0.66-1.38) \times 10^{-12}$ & $(0.66-1.38) \times 10^{-10}$ & $(0.66-1.38) \times 10^{-8}$ \\
\hline Granite with $\mathrm{P}_{\mathrm{H} 2 \mathrm{O}}=500 \mathrm{MPa}$ & 1073 & $2.6 \times 10^{5}$ & $(1.72-3.59) \times 10^{-6}$ & $(1.72-3.59) \times 10^{-4}$ & $(1.72-3.59) \times 10^{-2}$ \\
\hline Granite with $\mathrm{P}_{\mathrm{H} 2 \mathrm{O}}=2000 \mathrm{MPa}$ & 1473 & $0.5 \times 10^{2}$ & $(3.3-6.9) \times 10^{-4}$ & $(3.3-6.9) \times 10^{-2}$ & $(3.3-6.9) \times 10$ \\
\hline Basalt lava & in eruption & $10^{2}-10^{4}$ & $(0.64-137) \times 10^{-5}$ & $(0.64-137) \times 10^{-3}$ & $(0.64-137) \times 10^{-1}$ \\
\hline Andesite lava & in eruption & $10^{4}-10^{6}$ & $(0.65-138) \times 10^{-7}$ & $(0.65-138) \times 10^{-5}$ & $(0.65-138) \times 10^{-3}$ \\
\hline Dacite lava & in eruption & $\sim 10^{11}$ & $(0.65-1.38) \times 10^{-11}$ & $(0.65-1.38) \times 10^{-9}$ & $(0.65-1.38) \times 10^{-7}$ \\
\hline
\end{tabular}

Viscosities of magmatic rocks are after: [117] [167] [168] [169] [170].

these grains were tectonically delivered to surface by obduction and other tectonic processes. By other words, small grains of PGEs at the time of the magma-ocean were mostly concentrated within its top felsic layer, with some PGEs enrichment possibly forming within the intermediate magma layer. Meanwhile, grains of PGMs reaching mafic and ultramafic magma layers would sink through them relatively quickly. This is the main reason of very low PGE contents in mafic and ultramafic magmas (see Table 2).

It must also be taken into account that the settling of PGM grains within a layer (slab) can take place only before the solidification of that layer and eventually of the entire magma-ocean at all levels trapped the settling grains in some place within the layers. Given that various rocks and minerals have different melting points we can expect that some of them would begin solidifying before others. This would lead to the formation of solid layers within the magma-ocean at different depths prior to its complete solidification (e.g., the "forsterite layer" formation; [1] [77]). The high melting point of An-rich plagioclase also points to the possibility of the formation of the Anorthite and/or Bytownite layer within the magma-ocean. If such a layer had to form, it would prevent the further sinking of PGM grains, and they would be collected on the top of this solid layer (slab) within the forming crust. This brings forward the possibility of the existence of massive-type ore deposits formed above such a layer within the crust. Otherwise, with gradual solidification of the molten layer, the distribution of settling grains would more closely resemble to disseminated mineralization. At the same time, the melting point of plagioclase is much greater than that of felsic magmatic rocks, which would continue to be molten much longer than the plagioclase layer. Since the molten felsic rocks have lower density comparing with the solid plagioclase, their position would therefore also be above the plagioclase 
layer, continuing to accumulate the infalling grains.

Let us analyze the above facts in comparing with the available geological data. Examination of numerous data about the PGE ore deposits indicate that PGEs deposits and mineralization were found in anorthosite-bearing layered mafic intrusions (ALMIs) such as the Bushveld Complex (South Africa), the Stillwater complex (Montana, USA), the Duluth Complex (Minnesota, USA), and many others (e.g., [42]) known to contain the largest PGE deposits in the Earth.

The Bushveld complex includes two largest PGEs containing horizons (UG2 chromitites and the Merensky Reef) [42] [172]. Economic and high contents of PGEs in the anorthosite-bearing complexes were found in layers of chromitites, gabbroid cumulates (gabbros, leucogabbros, gabbronorites, norites, leuconorites, etc.) and anorthosites. The most famous PGE bearing chromitites are those of UG2 chromitite of the Early Proterozoic Bushveld Complex [42] [172]. Chromitites (from less than $1 \mathrm{~cm}$ to more than $2 \mathrm{~m}$ thick) in the Eastern Bushveld Complex are associated with anorthosites, norites, gabbros, and mostly with feldspatic bronzitites in the Upper and Lower Critical Zones [173]. PGE mineralization in the Aurora of Bushveld complex is associated with gabbros and leucogabbros [174].

The principal PGEs deposit of the Archean Stillwater complex, the J-M reef, is located within the Olivine-Bearing zone I (OB I) and composed of troctolite, dunite, gabbronorite and anorthosite [175]. The Picket Pin Pt/Pd deposit is a zone of disseminated PGEs-bearing sulfide which occurs in the upper $150 \mathrm{~m}$ of Anorthosite subzone II (AN II) of the Stillwater Complex [176].

PGEs content of troctolitic series in the Mid-Proterozoic Duluth Complex contains up to $14 \mathrm{ppm}$ of $\mathrm{Pt}+\mathrm{Pd}$ [177].

In the Archean Lac-des-Iles complex of Ontario (Canada) the highest precious metals mineralization was revealed in the Roby zone of the western gabbro consisting of interlayered cumulates of gabbroic (70\%), noritic (20\%), pyroxenitic (10\%) and minor anorthositic rocks [178].

Enrichment of PGEs in the Late Archean Legris Lake Complex, Wabigoon Subprovince (Canada) occurs in the leucogabbro breccia and mottled anorthosite [179].

PGE deposits were discovered in Late Archean-Early Proterozoic in Federovo Pansky ALMI (Kola Peninsula, Russia): Main Gabbronorite Zone consisting of contrasting alteration of gabbronorite, norite, pyroxenite and interlayers of leucocratic gabbro and anorthosite, and Upper Layered Horizon consisting of olivine-bearing troctolite, norite, gabbronorite and anorthosite [180].

It should be stated that even though chromitites are not gabbroic cumulates, they have strong relationships with the anorthosite-bearing gabbroic cumulates and anorthosites. Cameron [173] distinguished three types of chromitite-silicate rock series based on variations in modal proportions and presented in the Critical Zone of the Bushveld Complex: chromitite-bronzitite, chromitite-dunite, and chromitite-anorthosite.

There is evidence about direct presence of PGEs mineralization in anortho- 
sites. PGEs-bearing anorthosites are known in: the Archean Stillwater Complex [176]; the Early Proterozoic Bushveld Complex [172]; the Merensky Reef at Impala Platinum, Bushveld Complex [161]; the Middle Proterozoic Duluth Complex [177]; the Archean Lac-des-Iles complex of northwestern Ontario (Canada) [178]; the Late Proterozoic Ioko-Dovyren layered massif (Northern Transbaikalia, Russia) [181]; the Early Proterozoic Dzhugdzhur massif-type anorthosite (Aldan Shield, Russia) [182]; the Late Archean Legris Lake Complex (Wabigoon Subprovince, Canada) [179]; the Early Proterozoic Nadezhda sill-like gabbronorite body (Lukkulaisvaara layered intrusion, Fennoscandian Shield, Russia) [183]; the Sittampundi anorthosite Complex (Tamil Nadu, India) [184]; the Geransky massif (Far East, Russia) [185]; the Mid-Proterozoic Steel Mountain anorthosite (Canadian Appalachians, Newfoundland) [186]; Indian Head anorthosite (Newfoundland) [187] (Pilchin, 2014). Orsoev et al. [181] state that PGE mineralization occurs mainly in anorthosites in the Ioko-Dovyren dunite-troctolite- gabbro layered massif, Northern Transbaikalia (Russia).

It is also clear that anorthosites and especially An-rich anorthosites can be perfect traps and keepers for PGMs, because there are not so many magmas that able to re-melt them and release PGMs. Plagioclase of intermediate composition $\mathrm{An}_{40-60}$ has melting points in the range of $\sim 1700-1750 \mathrm{~K}$. However, plagioclase of intermediate composition has difference between liquidus and solidus temperatures of $\sim 200 \mathrm{~K}$ [154]. This means that none regular basaltic magma will be capable to re-melting such a plagioclase. Even pure albite, having melting point of $1391 \mathrm{~K}$, can be remelted only by some, mostly dry, basaltic magmas. It is unrealistic to suppose that any basaltic magma of typical composition would be capable of melting anorthite which has melting point of $1830 \mathrm{~K}$. Only komatiites and some picrites could be able to melt anorthosites to release PGMs. At the same time, elemental sulfur could get into anorthosites as fluid through porous and fractures and react with metals forming sulfides, which would be also trapped within anorthosites.

In a continuous borehole core (BV-1) drilled through the uppermost $2.8 \mathrm{~km}$ of the intrusion in the northern lobe of the Bushveld complex, typical rocks range upwards from troctolite, through gabbronorite and ferrogabbronorite to ferrodiorite, with extreme examples of anorthosite, magnetitite and feldspathic pyroxenite [188]. Most of the rocks contain at least 50\% plagioclase, and plagioclase contents average to $60 \%$ for all samples analyzed. Within the cross-section of the borehole forty-five anorthosite layers, ranging from 1 to $23 \mathrm{~m}$ thick, and twenty layers of magnetite have been identified. The mentioned authors find no evidence supporting flotation or prolonged suspension of plagioclase. The entire length of core discussed shows a change in upward plagioclase composition from $\mathrm{An}_{77}$ to $\mathrm{An}_{36}$.

PGMs were found in the Duluth Complex as inclusions in plagioclase and sulfide halos within plagioclase [189], and the highest concentration of PGEs in anorthositic series rocks found to date is $163 \mathrm{ppb}$ Pt. Marma [190] also reported about PGEs occurring in the poikilitic anorthite-rich plagioclase $\left(\mathrm{An}_{75}-\mathrm{An}_{95}\right)$. 
In numerous cases PGE mineralization and ore deposits are found in gabbroic and noritic rocks which are gabbroic cumulates (plagioclase rich rocks). Moreover, chromitite layers of up to $20 \mathrm{~m}$ thick are known to concentrate in the Anorthosite unit [191] and at the top of the Upper Leucogabbro unit of the Middle Archean ( 2.97 Ga) Fiskenæsset Complex, SW Greenland [192]. Anorthosite bearing plutonic suite of Middle Archean $(\sim 3.1 \mathrm{Ga})$ containing chromitite bodies and chromite deposits is known in the Nuggihalli greenstone belt, Dharwar craton (India) [193]. These facts clearly point at trapping and concentration of chromites within anorthosites as well.

The various properties of the PGE- and gold-PGE-bearing formations within the conglomerate-quartzite formation of the Kursk Magnetic Anomaly of the Voronezh Crystalline Massif (Russia) are presented in [16]. This points at the possibility of trapping some PGEs in the silica-rich layers.

An excellent example of the settling of PGMs and minerals of some transitional elements within the komatiitic basalt lava lake in the Vetreny Belt (Baltic Shield) is described in [194], where authors clearly illustrated the distribution of Os, Ir, $\mathrm{Ru}, \mathrm{Cr}$ and Ni with a depth. Data presented in Table 3 of [194] display an evident pattern of enrichment in $\mathrm{Cr}, \mathrm{Ni}$, Os, $\mathrm{Ir}$ and $\mathrm{Ru}$ with a depth, clearly supporting concentration through the settling of heavy materials within the komatiitic magma. Certain elevated values of these elements somewhat close to their average values throughout the entire topmost layer of the lava can be explained by a relatively quick cooling and consequent sharp increase in the viscosity of the layer. However, the significant accumulation of these elements in the two bottom layers, in particular $\mathrm{Os}$, Ir and $\mathrm{Ru}$, is easily explained by their settling within the magma. In the same token, the enrichment observed for $\mathrm{Cr}$ and $\mathrm{Ni}$ in the second layer from the bottom compared to the bottom layer can be accounted by the relatively low density of these elements compared to PGEs, which would result in settling slower and solidifying magma before most of them could reach the bottom.

It should also be stated that very low concentrations of PGEs and PGMs in typical terrestrial magmatic rocks (see Table 2) and achondrites (see Table 3) clearly show that the typical mafic magmatic rocks are not able to trap PGEs and PGMs which would settle through them very fast. This is also the reason why typical mafic magmatic rocks cannot be either source or carrier of PGEs and PGMs for formation of PGEs ore deposits.

Everyone aforementioned clearly point at strong relationships between the anorthosites and other gabbroic cumulates (troctolites, gabbros, norites, etc.) with PGE mineralization and PGE deposits. Since, anorthosites represent the pristine continental crust, it is likely that they have been collected PGEs and PGMs at the time of the magma-ocean before their solidification. It is likely that they also were the initial containers of PGEs and PGMs which were found themselves within anorthosites and stack within them after their the solidification.

So-called gabbroic cumulates contain plagioclase of up to: $70 \%$ in troctolites, 
$65 \%$ in norites, and 55\% in olivine gabbro and gabbronorites [195]; $40 \%$ in chromitites [34] [161]; 65\% - 85\% in leuconorites [196]; 80\% in leucogabbronorites or mottled anorthosites [197]; 70\% - 80\% in anorthositic gabbro [198], and $85 \%-95 \%$ in anorthosites [199]. It is evident that all these rocks require presence of huge amounts of plagioclase which could be provided only by anorthosites. Anorthosites, norites and troctolites are also typical Moon rocks, containing extremely high volume of calcic plagioclase ( $94 \%-96 \%$ of anorthite): about of $90 \%, 60 \%$ and $60 \%$, respectively [198].

Interestingly, such rocks as norites, gabbros and anorthosites are known to generate families of rock associations (e.g., gabbro-norites, gabbro-anorthosites, norite-anorthosites, etc.), and troctolite which is known as olivine-rich and pyroxene-depleted relative of gabbro [200]. Both gabbros and norites contain only high-Ca plagioclases (labradorite-bytownite) and olivine, but gabbros contain clinopyroxene and norites containing mostly orthopyroxene; and all three anorthosites, gabbros and norites hold chromite as an accessory mineral [201].

It should be stated that no troctolite corresponding in composition to a partial melt of peridotite was found [200]. This means that formation of troctolite in ALMI could take place only by interaction of the plagioclase-rich rock (e.g., anorthosite) with ultramafic melt.

The Archean Stillwater Complex contains two main anorthosite zones AN I ( $\sim 370 \mathrm{~m}$ thick) and AN II ( 630 $\mathrm{m}$ thick) in the Middle-Banded Series, and five additional anorthosite subzones forming 20-to 90-m-thick layers [199]. The horizon at the top of AN II, its upper 20 - $30 \mathrm{~m}$ [202] is the PGE-enriched Picket Pin zone. However, the Olivine-Bearing zone I (OB I), composed of troctolite, dunite, gabbronorite and anorthosite, is host of the principal platinum-group element deposit of the Stillwater complex (Bushveld Complex) [175]. The Picket Pin Zone is of lower grade than the Main Zone and the ore is notably enriched in Pt and Pd relative to the other PGE's. Czamanske and Bohlen [199] state that it seems inconceivable that introduction of any new liquid could promote in situ crystallization of 370- and 630-m thick layers of plagioclase cumulates that contain 85 to 95 vol\% plagioclase and vary insignificantly in composition. Boudreau and McCallum [202] testify that the PGE-bearing anorthosites are enriched (relative to unmineralized anorthosites) in chalcophile and some incompatible trace elements, and that the sulfide-bearing zones occur within pyroxene-poor anorthosites.

The Bushveld Complex (South Africa) has been investigated in detail by various authors. At many localities in the Bushveld Complex, the sulfide mineralization is largely hosted by mela-, meso-, and leucogabbronorites, as well as norites and anorthosites [172]. The contact between the Main Zone and the underlying Platreef at Sandsloot is often defined by a mottled anorthosite [172]. The Northern Lobe mineralization is consistently Pd-rich, rather than Pt-rich, and there the Lower Zone is overlain by the Platreef and by the Grasvally norite-pyroxenite-anorthosite (GNPA) member [174]. In some places the transition between the Upper Critical and Main Zones of the Bushveld Complex is within or above 
the distinctive Giant Mottled Anorthosite [203]. Eales et al. [196] draw the boundary between the Critical and Main Zones at the top of the Bastard Unit (at the upper contact of the Giant Mottled Anorthosite). Well-defined cyclicity is exhibited by a transition from pyroxenite, through melanorite, norite (35\% $65 \%$ plagioclase) and leuconorite ( $65 \%-85 \%$ plagioclase) to anorthosite $(\geq 85 \%$ plagioclase) in the Bastard and Merensky Units [196]. The authors [196] reported presence of abrupt transitions such as chromitite-anorthosite-chromitite, harzburgite-anorthosite-harzburgite, and leuconorite-anorthosite-leuconorite for the Western Bushveld Complex. Mitchell and Manthree [203] demonstrate that the uppermost unit of the Upper Critical Zone (an anorthosite with large intercumulus pyroxene mottles, designated unit HW5 at the Impala Platinum Mines), whilst petrographically part of the Giant Mottled Anorthosite, has some chemical attributes that link it to the Main Zone, and they attribute the hybrid geochemical signature of HW5 unit to partial melting of the anorthosite, due to an influx of the Main Zone magma above it. The Merensky Reef contains the Merensky mottled anorthosite of about $5 \mathrm{~m}$ thick, and the Bastard cyclic unit contains the Giant mottled anorthosite c. $50 \mathrm{~m}$ thick [204]. PGEs were revealed in anorthosites of the Merensky Reef at Impala Platinum (Bushveld Complex) [161].

The Duluth Complex (Minnesota, USA) consists of an extensive cap of anorthositic rocks which are underlain and intruded by troctolitic rocks. Anorthositic series rocks are found as inclusions in the troctolitic series on a scale from centimeter-sizes to mappable units [205]. All the rocks in the anorthositic series are plagioclase cumulates and the anorthosite inclusions are presented in the olivine diabases in the North Volcanic Group lavas. Plagioclase shows a gradual decrease in An content upward in the section from An85 in the basal zone to An40 in the upper layered unit. Weiblen and Morey [205] led to conclusion that the anorthositic series is older than the troctolitic series, and possibly these two series are not genetically related.

The fact of increasing anorthite-content (and density) in plagioclase with a depth within the layered intrusions shows that it is cumulate plagioclase representing the primordial plagioclase layer of the magma-ocean, like the oldest $\mathrm{Lu}$ nar crust. Inversion of the density distribution of olivine (increase of $\mathrm{Mg}$-content and decrease of $\mathrm{Fe}$-content downwards) in layered intrusions indicate that olivine is not part of primordial cumulates and was delivered later by magma flows. Increasing melting points of both plagioclase and olivine with a depth the high melting point of olivine-containing magma indicate necessary to re-melt and intrude the plagioclase layer to form local magma chambers within it at different levels. To intrude the plagioclase layer, magma must have a heat energy in excess of that required to melt the plagioclase, providing the necessary latent heat of fusion. Analysis of the difference between melting points of coexisting olivine and plagioclase inclusions in the Bushveld layered intrusion shows the disparity to be $\sim 200$ - $400 \mathrm{~K}$; and for carbonaceous chondrites it is $\sim 250-400 \mathrm{~K}$. This means that to re-melt the plagioclase and intrude the plagioclase layer, magma must 
have a significantly higher melting point than plagioclase ( $1830 \mathrm{~K}$ for anorthite, $1391 \mathrm{~K}$ for albite) or to be highly overheated. In contrast, such difference between the melting points in the Lunar meteorite Sayh al Uhaymir 300 is only $\sim 100-290 \mathrm{~K}$, which explains preservation of the early anorthositic Lunar crust. Magmas with greatest temperatures could intrude the plagioclase layer's lower parts, while moderate-temperature magmas could only intrude upper ones. Each such intrusion has created a magma chamber and relative cyclic unit.

It is known that gabbroic cumulates were formed later during interaction of anorthosites with melts. For example, troctolites were most likely formed during interaction of komatiites or dunites (dunite-chromites) with anorthosites. The enrichment of chromites with PGEs could have happened by simultaneous their accomplishment above a solid barrier within the magma-ocean (e.g., the "forsterite layer") or by underplating an anorthosite layer by dunite-chromite melt with remelting of the anorthosite layer and PGEs accumulation within the anorthosite layer (according to the Stokes law) into the dunite-chromite layer where PGEsare finally accumulated. Similar situation could take place with underplating of anorthosite layer by komatiites or other ultramafic melt with formation of troctolites enriched with PGEs from the anorthosite. Interaction of anorthosites with different ultramafic magmas in different proportions would have formed gabbroic cumulates which would inherit and in some cases would be enriched in PGEs. Possibilities of such underplating are in line with the presence of ALMIs (e.g., Bushveld Complex, Stillwater Complex, etc.) having ultramafic layer at the bottom of each ALMI complex, as well as ultramafic layers could be presented at other levels within the ALMI inside each cyclic unit. It is also in agreement with the facts [206] [207] showing that temperature of melt forming dunite pipes (Mooihoek, Onverwacht, Driekop and Twyfelaar) within the Bushveld complex were in excess of 1786 - $2096 \mathrm{~K}$. The Driekop and Mooihoek pipes are emplaced in the Upper Critical zone, the Onverwacht and Twyfelaar pipes occur in the Lower Critical and Lower zones, respectively. The core-zones at Mooihoek and Onverwacht consist of hortonolite dunite and hortonolite wehrlite pegmatites (hortonolite is a moderately iron-rich olivine; average composition is $\mathrm{Fo}_{50-44}$ that points at melting temperature $\left.\mathrm{T}_{\mathrm{m}} \sim 1786-1826 \mathrm{~K}\right)$. The core-zone at the Driekop pipe differs somewhat in that it consists of discrete mineralized pods and veins of iron-rich dunite and iron-rich wehrlite (average composition is $\mathrm{Fo}_{73-72}$ with $\left.\mathrm{T}_{\mathrm{m}} \sim 1974-1981 \mathrm{~K}\right)$. Scoon and Mitchell [208] point at presence of two principal assemblages in the Onverwacht pipe with olivine $\mathrm{Fo}_{83-80}\left(\mathrm{~T}_{\mathrm{m}} \sim 2028-2049 \mathrm{~K}\right)$ and olivine $\mathrm{Fo}_{64-44}\left(\mathrm{~T}_{\mathrm{m}} \sim 1786-1921 \mathrm{~K}\right)$. Here for estimations of $\mathrm{T}_{\mathrm{m}}$ of geological rock by olivine phenocrysts composition, a method described in [78], was employed. We must underline that for effective re-melting of rocks in layer (slab) and underplating this layer, the temperature of magma must be in excess, because it must provide a heat energy for warming rock to its melting point overcoming heat of latent fusion and stay molten by itself. Extremely low viscosities of ultramafic melts also support possibility of underplating of crustal layers by ultramafic melts. Hall [117] described dunitic magma with unusually low viscosity 
from the Nordre Bumandsfjord pluton (approximately of Cambrian age) in Norway caused partial melting of gabbroic xenoliths and modified by assimilation of gabbroic and sedimentary material. It should be stated that chromite is a widespread accessory mineral in komatiites [209], it is least abundant in highly magnesian chrome-undersaturated lavas and most abundant in strongly differentiated layered cumulate bodies; the natural range of $\mathrm{Cr}$ contents in olivine-chromite cumulates should be from $\sim 5 \times 10^{3}$ to $10^{4} \mathrm{ppm}$ and chromite is a very widespread accessory mineral in almost all komatiitic rocks. It typically makes up a few tenths of $1 \%$ of the rock by volume, but in some cases it may be much more concentrated. The most extreme example of this is the Shurugwe (formerly Selukwe) massive chromitite deposits of Zimbabwe [210] [211], where chromitite seams up to $10 \mathrm{~m}$ thick are associated with highly altered, deformed and metamorphosed $3.4 \mathrm{Ga}$ serpentinites of probable komatiitic affinity.

In the Moon, where anorthosite layer was preserved and never was re-melted, temperature of melt was not in excess compare to the melting point of Lunar anorthosites. Analysis of data for Lunar meteorite Sayh al Uhaymir 300 comprising anorthositic clasts presented by Hudgins et al. [212] and shows that its matrix contains inclusions of plagioclase $\left(\mathrm{An}_{94-98} ; \mathrm{T}_{\mathrm{m}} \sim 1804-1821\right)$ and olivine $\left(\mathrm{Fo}_{62-72} ; \mathrm{T}_{\mathrm{m}} \sim 1907-1975 \mathrm{~K}\right)$, and mineral fragments of plagioclase $\left(\mathrm{An}_{93-96} ; \mathrm{T}_{\mathrm{m}} \sim\right.$ 1799 - 1812) and olivine $\left(\mathrm{Fo}_{62-73} ; \mathrm{T}_{\mathrm{m}} \sim 1907-1982 \mathrm{~K}\right)$. This means that excess of temperature in the range $103-170 \mathrm{~K}$ was not enough for re-melting these plagioclase fragments.

Scarfe et al. [213] show that viscosity of anorthite is relatively low at temperatures of its subsolidus temperature and it changes from $2.15 \mathrm{~Pa}$ s at $1898 \mathrm{~K}$ and $4.07 \mathrm{~Pa} \cdot \mathrm{s}$ at $1830 \mathrm{~K}$ in liquid state to $25.2 \mathrm{~Pa} \cdot \mathrm{s}$ at $1673 \mathrm{~K}$ and $\sim 37 \mathrm{~Pa} \cdot \mathrm{s}$ at $1648 \mathrm{~K}$ in solid state, which are still in many orders lower than viscosity of albite. This means that if the high temperature magma underplated anorthite layer containing PGEs in it and magma would be able only heat up the anorthite to high temperature, but not melt it (e.g., in the case when magma temperature is not high enough or volume of magma is relatively small) the viscosity of heated anorthite could be low enough for fast settling within it PGEs and PGMs with their deposition within or just above the ultramafic magma complex that underplated the anorthite layer.

Analysis of appearance of PGEs in different mineralization zones and ore deposits show that in numerous cases the PGE economic concentrations are related to their association with chromites/chromitites. In case of PGE associations with chromites, sizes of combined grains were significantly larger than PGE grains and they were sinking within the magma-ocean much faster and should have sank to levels of the middle mantle and core during the time span of magma-ocean existence. However, their numerous presence in different PGE ore deposits shows that not all grains of PGEs with chromite sank to the great depths within the Earth. This fact could be explained by formation of "forsterite layer" [66] [77] which prevent them from sinking to the deep levels.

Let us analyze from this point of view increase of PGE concentrations in ko- 
matiites from the Early Archean $(>3.5 \mathrm{Ga})$ to Late Archean. It is well known that melting temperature of komatiites increases with increase of $\mathrm{MgO}, \mathrm{MgO}$-content of komatiites decreases with age youngling, melting point of komatiites is also decreasing with age youngling and viscosity of melt increases with temperature decline. Thus, it is clear that lower contents of older komatiites in PGEs than in young komatiites could be explained by higher viscosity, longer time of cooling during hotter early periods of Earth evolution and higher settling speed of heavy species in higher viscous melt.

All this indicates that PGEs and PGMs during the early Earth evolution could have been prevented from sinking toward a center of the Earth by formation of solid layers (e.g., the "forsterite layer", dunite-chromite layers, anorthite layer, etc.) as well as collecting micro-grains of PGEs and PGMs within anorthosite or other silica-rich layers.

All the above-mentioned demonstrates that the initial concentration of PGEs and PGMs is related to their accumulation within the magma-ocean and they being trapped in the forming solid layers of rocks and minerals at shallow depths with high melting points and within highly viscous magmatic layers, mostly represented by plagioclase melt and felsic magmas.

It is also important to take in consideration that processes of plate tectonicsduring the Hadean and Early Archean were not operational in the Earth, and neither were operational processes of exhumation at the time of magma-ocean. There was no water-ocean before $\sim 3.42-3.26 \mathrm{Ga}$ [77] [78] and it means that any metal transport by aqueous fluids, the main transport tool in hydrothermal ore deposits (e.g., [214]), was not possible.

\section{Relationships of PGEs and PGMs Ore Deposits Formation with Process of Serpentinization}

Five largest known PGE deposits in the Earth are [215]: the Merensky and UG2 Chromitite Reefs of the Bushveld Complex (South Africa), the Main Sulfide Zone of the Great Dyke (Zimbabwe, South Africa), the Johns-Manville (JM) Reef of the Stillwater Complex (USA), and series of the Noril'sk-Talnakh deposits (Northern Russia).

The first four largest PGE deposits are related to large anorthosite-bearing layered mafic-ultramafic intrusions (ALMI). ALMI are rare, but host magmatic ore deposits containing most of the world's economic concentrations of PGEs. "PGE reefs" are stratabound PGE-enriched lode mineralization in mafic to ultramafic layered intrusions [38]. Contact-type Cu-Ni-PGE deposits is another relatively common type of PGE deposits [38]. PGE-enriched sulfide mineralization is also found near the contacts or margins (contact-type Cu-Ni-PGE deposits) of ALMI [216]. The largest contact-type Cu-Ni-PGE deposit is also mined in the Bushveld Complex [38].

The fifth largest and unique PGE-Cu-Ni Noril'sk and Talnakh deposits (Russia) are located in the northwest flank of the Triassic basalt trap formation of Siberia. They were formed on regional basement, which comprises Archean crys- 
talline complexes and Lower-Middle Proterozoic volcano-sedimentary rocks and they were subjected to multiple tectono-magmatic transformations [217]. The main tectonic peculiarity of the region is presence of several extended long-lived Early Proterozoic rifting structures [217]. The authors [217] led to conclusion that ore elements of these deposits (except iron) are derived from the Earth crust rather than from the mantle.

Another usual type of PGE deposits is the Ural-Alaskan type: the lode sources of the most significant economic PGE placer resources and reserves [218] [219]. The Ural-Alaskan type complexes consist of large intrusive bodies of dunite, chromitite, wehrlite, clinopyroxenite, amphibole gabbro, and hornblendites. In contrast, Alpine type (ophiolitic lherzolite type) mafic-ultramafic complexes are known to contain only modest economic concentrations of PGE in placer deposits [219].

Potentially economic deposits of Pt and Pd occur in a range of hydrothermal deposits without obvious direct or even indirect association with magmatism [220]. A number of PGE deposits are by-products or potential by-products from the production of such metals as uranium, gold and base-metals (e.g., orogenic gold deposits) [220].

One of the main patterns of magma-involved PGE deposits is presence of high-temperature ultramafic magmatic rocks (mostly dunites) in all of them. Even in Noril'sk and Talnakh PGE deposits (Russia) presence of significant amounts of Mg-rich magmatic rocks was reported [217]. Presence of thick ultramafic layers is one of the main characteristics of ALMIs. Moreover, rich PGEs content in some dunite pipes (e.g., Mooihoek, Driekop, Onverwacht and Twyfelaar dunite pipes, Bushveld complex, South Africa) were discovered [206] [207] [221]. One of the main properties of ultramafic and Mg-rich rocks is their ability to be serpentinized with presence of water and temperature within the range of about $473-729 \mathrm{~K}$ (and even up to $843 \mathrm{~K}$ ) which unavoidably would be reached during cooling of magmatic rocks and/or their later re-heating. It is in agreement with presence of the Ural-Alaska and Alpine types of PGE deposits which are always formed within the serpentinite and/or ophiolite belts in association with the serpentinized ultramafic rocks. Many PGE deposits are associated with chromites and/or chromitites which known to associate with dunites. Serpentinites are known in almost all ALMIs: Bushveld Complex [172] [221], the Great Dyke of Zimbabwe [222], Stillwater Complex (Montana, USA) [223]; Duluth complex (USA) [224], Lac-Des-Iles Complex (Northwestern Ontario, Canada) [225], Burakov intrusion (Fennoscandian Shield, Russia) [226], Mt. General'skaya (Kola Peninsula, Fennoscandian Shield, Russia) [180], the Guli Clinopyroxenite Dunite Massif (Siberian Craton, Taimyr Province, Russia) [227], and in other numerous PGE deposits relating to ALMIs.

It should be stated that formation of PGE deposits in association with continental rifts (e.g., Noril'sk and Talnakh PGE deposits of Russia) and some PGE deposits not related to magmatic processes (e.g., PGEs associated with the orogenic gold deposits) are most likely also related to the serpentinization processes, 
because most continental rifts since Middle Proterozoic were formed with involvement of riftogenic ophiolites [228] [229] and the most orogenic processes have been also involved serpentinites and/or ophiolites. McKelson et al. [227] led to the conclusion that serpentinization, possibly driven by metasomatising fluids, seems to be the important process in PGE concentration. Interestingly, serpentine is one of principal minerals of carbonaceous chondrites [69], which are usually used as the standard for PGEs content (in CI chondrites) for a comparison of PGE contents in the terrestrial rocks.

From this point of view, it is important to analyze the possible relationships of PGE and PGM in ore deposits with the serpentinization process.

Since serpentinization process is known for its association with more powerful tectonic processes (e.g., obduction, orogenic, thrusting, exhumation, etc.) and generation of overhigh pressure [77] [159] [230] [231], it is obvious that tectonic factors play important role both in transportation and formation of the PGE deposits.

The processes of the PGEs enrichment can be related to the following processes: initial collecting of PGEs within magma-ocean above solidified ultramafic layer (forsterite, forsterite-dunite, dunite, dunite-chromite, etc.); initial trapping of PGEs within highly viscous layers of magma-ocean (felsic and plagioclase layers) with following their liberation, re-distribution and secondary enrichment by means of magmatism (re-melting of PGEs containing rocks) and/or alteration (by sulfur, water solutions, etc.). The formation of PGEs mineralization and deposits has been carried out at some depths from which they were tectonically delivered to shallow depths or earth's surface. It is in agreement with the fact of PGE abundances in the Samail Ophiolite (Oman) and the proposition that PGE composition very similar to Lorand et al. [83] estimates for the Primitive Upper Mantle of the Earth. But sulfur and hydrothermal activity are impossible within the upper mantle where forsterite, dunite and dunite + chromite layers were formed during solidification of magma-ocean and where most of PGEs were initially trapped and enriched. This means that first step of the PGEs transport to area of their mineralization and/or PGE deposits formation always was tectonic one.

PGE mineralization and deposits are usually associated with anorthosites and plagioclase-rich rocks. Therefore, it is important to mention that huge anorthosite massifs and ALMIs were emplaced tectonically to their present positions.

Really, since PGEs are extremely dense they should have sunk to the core or other great depths during the Earth accretion and evolution of magma-ocean. The traps for PGEs were formed only by either late veneer (late bombardment/ infall) or formation of solid layers within the magma-ocean at some depths (e.g., "forsterite layer"). At the same time, most of typical magmas contains low amounts of PGEs and such magmas as MORB and Alkali Basalt contain negligible amounts of PGEs (see Table 2) that makes it unrealistic or even impossible to deliver PGEs to the surface from large depths. Moreover, PGEs content in the primary mantle and bulk crust is also extremely low (see Table 2 ) and their sim- 
ple melting would not provide sufficient amounts of PGEs. This means that PGEs were first concentrated somehow at different depths and then they were delivered to the surface. The possible processes of delivery of such concentrations to the surface are tectonic (e.g., obduction, thrusting, uplift, exhumation, etc.). All these processes are known to associate with serpentinization process [159] [230] [231]. This means that serpentinization process must have played a crucial role in the PGEs delivery to the surface and the main transport of PGEs to the final location of PGEs ore deposits was realized tectonically. It is in complete agreement with the following facts: PGE ores are presented in ophiolites and serpentinites, PGEs containing layered intrusions contain ultramafic layers and serpentinites, Ural-Alaskan type complexes are presented in regions of obvious obduction and formation of ophiolites and serpentinites.

The most important fact is that the ultramafic layer in layered intrusion containing PGE deposits does not need to be serpentinized by itself, because it would just destroy the complex. Serpentinization of layer below the layered intrusion would either destroy the intrusion or cause its vertical exhumation. The latest is possible in the Ural-Alaskan type complexes around the world, which are frequently associated with the PGE enriched placer deposits. Really, placer deposits can best be formed in the case of complete destruction of PGEs containing layers/blocks with following interaction with water flows and other leaching agents.

One of the major characteristics of the PGE deposit formation is the fact of their presence in very thin layers within huge complexes. For example: the Merensky Reef, in Impala Platinum Mines (Bushveld Complex) is only $46 \mathrm{~cm}$ thick and consists from bottom to top of leuconorite, anorthosite, chromitite and a very coarse-grained melanorite [34]; the Bastard cyclic unit of the Bushveld Complex contains thin basal chromite usually $<5 \mathrm{~mm}$ thick [204]; chromitites in the Critical Zone (Bushveld Complex) range from less than $1 \mathrm{~cm}$ to more than 2 $m$ thick [173]; in the Bird River Sill (Manitoba, Canada) chromite layers are concentrated within the upper part of the ultramafic series, they are typically $<20$ $\mathrm{cm}$ thick (maximum of ca. $1 \mathrm{~m}$ thick) and have planar, regular contacts with adjacent dunite and peridotite layers [232]; marker chromitite is a prominent 48 cm thick layer of the Lower Critical Zone (Bushveld Complex) [233]; three massive chromitite layers, each with thicknesses between 28 and $35 \mathrm{~cm}$ were reported for the western Bushveld Complex [234]; Mondal and Mathez [235] called the massive $70 \mathrm{~cm}$ thick UG2 chromitite layer of the Bushveld Complex; in borehole core (BV-1) drilled through the uppermost $2.8 \mathrm{~km}$ of the intrusion in the northern lobe of the Bushveld complex forty-five anorthosite layers, ranging from 1 to $23 \mathrm{~m}$ thick, have been identified [188]. All of these layers are significantly horizontally extended. Zientek [38] states that within the layered igneous intrusions the PGE mineralized intervals are thin, generally centimeters to meters thick, relative to the stratigraphic thickness of layers in an intrusion that varies from hundreds to thousands of meters, and reef-type mineralization is laterally persistent along strike, extending for the length of the intrusion, typically tens to hundreds of kilometers. Such layers as well as ALMIs could not be 
formed near the surface. Moreover, all those thin layers have survived during billions of years of tectonic perturbations and it is really enigmatic. It should also be mentioned that each ALMI consists of cycling units which not only survived, but also keep their position through billions of years. Presence of undisturbed small bodies of chromite-containing reefs and thin PGE plates among layers of layered intrusions signify the exhumation of layered intrusions within a single block during obduction or serpentinization of underlying ultra-basic rocks (e.g., dunites, harzburgites). This means that oldest ALMIs (e.g., Stillwater Complex, Montana and some PGE-rich complexes of the Canadian Shield) could be among the first witnesses of plate tectonics.

Evidence of presence of giant obducted plates around the world is overwhelming. Among the giant obducted plates are known: Oman Ophiolite (Arabian Peninsula), Bay of Islands Ophiolite (Canada), and Plates in Caledonian Orogens (Scandinavia). Obduction of giant plate on the Fennoscandian Shield took place in Early Proterozoic [236]. Results of detailed analysis of repeated obduction in the Appalachians [237] show that initial obduction of oceanic lithosphere within the present Appalachian region started with detachment and thrust of the entire Greenville Province onto the Canadian Shield (see also [238]). It should also be stated that repeating of obduction in the same region could cause delivery of rocks of the deep-seated layers to the surface or to very shallow depths through a few steps as plates or plate remnants [230]. Repeated obduction pro- cesses are known in the regions of Alps, Appalachians, Urals, California, Japan, Russian Far East, Norway, Mozambique, and many others (e.g., [237]). Pilchin [187] presented results of research discussing in more detail an involvement of forsterite and dunite layers of the oceanic lithosphere in obduction during formation of the Appalachians.

It was shown earlier [1] that forsterite layer in continents is usually located at depths of $70-120 \mathrm{~km}$. Pilchin and Eppelbaum [77] proposed that dunite and chromite were solidified next after forsterite within the magma-ocean and they would form a layer right above the forsterite layer. Obviously, it is clear that presence of forsterite xenoliths as well as dunites at and near the earth's surface, is possible only if they were delivered to the surface by some geodynamic (tectonic) processes. To examine this supposition a special research was accomplished [187].

Since unserpentinized forsterite and dunite layers' rocks are characterized by velocities of $8.5-8.7+\mathrm{km} / \mathrm{s}$ (e.g., [119] [187]), analysis of seismic data at depths where such velocities were detected within the Appalachians and some other regions was accomplished. Obtained results indicate that layers with velocities observed in some regions are: $8.6 \mathrm{~km} / \mathrm{s}$ dipping eastward from 50 to $60 \mathrm{~km}$ beneath the southeastern Greenville province (northern NY state and eastern Ontario) [239]; about $8.5-8.6 \mathrm{~km} / \mathrm{s}$ at $\sim 60 \mathrm{~km}$ depth beneath southern Quebec (Canada) [240]; $>8.4 \mathrm{~km} / \mathrm{s}$ and $>8.6 \mathrm{~km} / \mathrm{s}$ were reported at depths of $\sim 40-60 \mathrm{~km}$ beneath the Flin Flon Domain and Western Interior Platform of the Trans-Hudson Orogen (Canada) [241]; $8.7-8.8 \mathrm{~km} / \mathrm{s}$ at $52 \mathrm{~km}$ depth beneath the Gaspe Peninsula 
(Canada) [242]; $8.5 \mathrm{~km} / \mathrm{s}$ at 40 - $50 \mathrm{~km}$ depths beneath the Gaspe Peninsula (Canada) [243]; $8.4-8.7 \mathrm{~km} / \mathrm{s}$ in the upper part of the mantle beneath the Gulf of St. Lawrence and beneath the northeastern Newfoundland [244]; $8.5 \mathrm{~km} / \mathrm{s}$ at $\sim 46.3 \mathrm{~km}$ depth beneath the Gulf of St. Lawrence (Northern America) [245]; $\sim 8.5 \mathrm{~km} / \mathrm{s}$ at depth of $\sim 55 \mathrm{~km}$ beneath Newfoundland Appalachian orogen [246]; $8.5 \mathrm{~km} / \mathrm{s}$ at depths 55 - $65 \mathrm{~km}$ below the Appalachians in the Canadian Maritimes [247]; $8.5 \mathrm{~km} / \mathrm{s}$ at a depth of about $13 \mathrm{~km}$ beneath the central ridge in the Norwegian-Greenland Sea [248]; up to $7 \mathrm{~km}$ thick lower crustal body with velocity of $8.5 \mathrm{~km} / \mathrm{s}$ in Norwegian Caledonides [249]; $8.5 \mathrm{~km} / \mathrm{s}$ under southeastern Møre Basin (mid-Norwegian Margin) at depths of 22 - $25 \mathrm{~km}$ [249]; 8.5 $\mathrm{km} / \mathrm{s}$ at depths of $\sim 33-43 \mathrm{~km}$ within the lowest crust across the main Caledonian suture between Barentsia and Baltica (Barents Sea) [249]; block of lower crust with $8.5 \mathrm{~km} / \mathrm{s}$ at a depth of $14.5-18 \mathrm{~km}$ below the southern Vøring Basin (mid-Norwegian Margin) [249]; $8.8 \mathrm{~km} / \mathrm{s}$ apparent velocity results at a depth of $31 \mathrm{~km}$ under Fairbanks (Alaska) and dipping southward under the Alaska Range to $\sim 48 \mathrm{~km}$ depth [242]; $8.6 \mathrm{~km} / \mathrm{s}$ at depths of $\sim 28.5-30.0 \mathrm{~km}$ beneath the South Island (New Zealand) [250]; $8.6-8.7 \mathrm{~km} / \mathrm{s}$ in the local upper mantle block between 45 and $60 \mathrm{~km}$ beneath the Aralsor rift (the Pre-Caspian Basin) [251]; 8.5 $9.0 \mathrm{~km} / \mathrm{s}$ a the depth of $43-48 \mathrm{~km}$ in the South Caspian Basin [252]; $8.7 \mathrm{~km} / \mathrm{s}$ at depths of $\sim 41-43 \mathrm{~km}$ and $8.5 \mathrm{~km} / \mathrm{s}$ at depths of $\sim 40-42 \mathrm{~km}$ beneath the Mirnyi kimberlite field (eastern Siberian craton) [242]. These data clearly show that position of forsterite layer in the Appalachians region and numerous other regions could be at relatively shallow depths. In some regions of obvious repeated obduction (e.g., Norwegian Caledonides) this layer may be presented within the Earth crust that cannot be reworked by any processes other than obduction.

Presence of huge amounts of serpentinized and unserpentinized dunites can prove that obduction process did take place in a studied region [187]. For example, huge amounts of serpentinites in the Appalachians could be found almost everywhere and huge amounts of dunites are known: massive chromite-bearing dunite in the Nadeau Ophiolitic Mélange (Quebec Appalachians, Canada) [253]; in the Baltimore mafic complex (Maryland, USA) [254]; alternating layers of dunite and chromite-rich dunite in the Quebec Appalachians [255]; serpentinized dunites from the Webster-Addie ultramafic body (about $10 \mathrm{~km}$ long and 5 km wide) (North Carolina, USA) [256]; Blue Ridge dunites of North Carolina [257]; dunites of the Bay of Islands Ophiolite (Canada) [258]; dunites of the Sept-Îles Anorthosite Complex (Quebec, Canada) [259]; dunites of the Thetford Mines Ophiolite Complex (Canada) [260]; chromitites of the Middle Arm Brook are enveloped by dunites (Advocate ophiolite complex, Baie Verte Peninsula, Newfoundland, Canada) [137]. These data noticeably testify that huge amounts of dunites were directly involved in obduction processes in the Appalachians region. Moreover, in most cases dunites in the Appalachian regions are present in association with chromites and they are serpentinized. Close to the region, dunites are also known in Jamaica and Tobago [261], in the Moa-Baracoa massif (eastern ophiolitic belt of Cuba) [262], and in some other regions. 
It is known that anorthosites are usually associated with ultramafic rocks. Such a pattern was also observed in the Appalachian region: the Steel Mountain anorthosite is located within the Long Rang Fault as a part of the Baie VerteBrompton line [263]; Roseland anorthosite within the Blue Ridge Province [264]; Indian Head anorthosites in the western Newfoundland [265]; anorthosites in the northern Gulf of St. Lawrence [266]; anorthosites in the Arden Pluton, Appalachian Piedmont (Delaware and adjacent Pennsylvania) [267]; the Honey Brook anorthosite in Pennsylvania [268]; anorthosites of the CRUML Belt and the central Appalachians [269]; the Montpelier Anorthosite within the Blue Ridge Province [270]; the Montpelier Anorthosite in Virginia [271].

It was also shown [187] that dunites and associated with them chromites and chromitites in the Appalachian region in many cases are relatively rich in PGEs. All these facts led to the conclusion that forsterite and dunite (dunite + chromite) layers were deeply involved to obduction processes in the Appalachians region [187].

PGE enrichments are also known to be found in relation with the olivine-rich rocks (dunites, peridotites) in numerous regions of ophiolite formations. These formations are characterized by serpentinization of Mg-rich olivine, which links the ophiolites with the forsterite layer, with dunites solidifying on top of it. Associations of chromites with serpentinites are also known in the following areas: chromitic serpentinites in Newfoundland, Canada and Baltimore Mafic Complex, USA [187] [272]; chromite-serpentinite layers in the Newlands pit, Coobina Intrusion, Pilbara Craton [273]; Kalung-Kalungan island of North Borneo [274], etc. Moreover, chromitite is a part of the Thetford Mines ophiolite, Canada [275].

For analysis of contents of PGEs in rocks associated with serpentinites, a careful analysis of published data has been performed (Table 9 and Table 10). In Table 9 only examples with maximal PGEs content of $3.2 \mathrm{ppm}$ and higher were presented and in Table 10 only examples above $0.5 \mathrm{ppm}$ and less than 3.0 ppm are given. Cases with the RGE contents (single PGEs and total) in rocks associated with serpentinites of a few hundreds of ppb, which are about two orders of magnitude of PGE contents in typical magmatic rocks, are numerous, but they are too low for economic PGE deposits and much lower than the PGE contents in chondrites.

Çina et al. [283] reported four types of PGE mineralization in the Albanian ophiolites with the PGE contents ranging from: 1) 160 - $350 \mathrm{ppb}$, 2) $580-2050$ ppb, 3) 2195 - $8820 \mathrm{ppb}$, and 4) 1943 - $9730 \mathrm{ppb}$.

PGE deposits are usually associated with chromites and/or chromitites, which in turn are associated with dunites (Mg-rich end member of the peridotite family) having maximal effect during serpentinization process. This is an agreement with the fact of presence of significant amounts of PGEs associated with chromites/chromitites usually enveloped by dunites found in regions of obduction, formation of ophiolites and serpentinites. Thus, it is obvious that high contents of PGEs in chromites even in regions with absence of clear evidence of serpenti- 
Table 9. High PGE contents in rock inclusions within ophiolites, serpentinites, peridotites and associated with serpentinites (including samples).

\begin{tabular}{cccc}
\hline Area, region & Rock & $\begin{array}{c}\Sigma \text { PGE, } \\
\text { ppm }\end{array}$ & Reference \\
\hline Cliff, Shetland ophiolites & chromite-rich dunite & $\leq 60.0$ & {$[41]$} \\
Cliff, Shetland ophiolites & chromite-poor dunite & $\leq 6.4$ & {$[41]$} \\
Veria, Greece & chromite & $\leq 25.0$ & {$[276]$} \\
Pindos, Greece & chromites & $\leq 4.22$ & {$[35]$} \\
Eastern Desert, Egypt & chromitites & $\leq 3.2$ & {$[277]$} \\
Kytlym, Northern Urals & chromitites & $\leq 61.0$ & {$[40]$} \\
Korydallos, Pindos ophiolite & - & $\leq 6.864$ & {$[278]$} \\
Butirin, Northern Urals & - & 22.972 & {$[279]$} \\
Nurali complex, Urals & CHRI, CHRII & $\leq 11.61$ & {$[280]$} \\
Ouen Island, New Caledonia & - & 11.5 & {$[281]$} \\
Al 'Ays Ophiolite, Saudi Arabia & - & $\leq 25.5$ & {$[282]$} \\
Albanian ophiolites & - & $\leq 11.1$ & {$[283]$} \\
Legris Lake Complex, Canada & (Pd+Pt only) & $\leq 3.625$ & {$[179]$} \\
Lac Des Iles Mine, Canada & (Pd only) & $\leq 7.62$ & {$[284]$} \\
Jinchuan complex, China & - & $\leq 3.524$ & {$[285]$} \\
State Line District, Appalachians & Chromite & $\leq 5.0$ & {$[286]$} \\
Mayari-Baracoa Ophiolite Belt, Cuba & Chromite & $\leq 3.7$ & {$[287]$} \\
Misheguk Mountain, Alaska & Chromite (Pt only) & $\leq 4.2$ & {$[288]$} \\
Misheguk Mountain, Alaska & Chromite (Pd only) & $\leq 4.7$ & {$[288]$} \\
Bear Creek, Alaska & (Pt only) & $\leq 6.5$ & {$[288]$} \\
Danielson Creek, Alaska & (Pt only) & $\leq 10.0$ & {$[288]$} \\
Halibut Bay \& Sturgeon River, Alaska & Chromite (Pd only) & $\leq 11.52$ & {$[288]$} \\
Halibut Bay \& Sturgeon River, Alaska & Chromite (Pt only) & 5.453 & {$[288]$} \\
Dust Mountain, Alaska & Chromite (Pd only) & 11.936 & {$[288]$} \\
Dust Mountain, Alaska & Chromite (Pt only) & 8.918 & {$[288]$} \\
\hline & & &
\end{tabular}

nization and ophiolite activity could also be treated as related to those, because blocks containing those chromites/chromitites could represent parts of greater blocks which were partially serpentinized. The mechanism of such thrusting is described in [159] [230] [231]. From this point of view, some PGE concentrations associated with chromites from known PGE deposits are accomplished (Table 11).

Table 12 shows comparison of the mean PGE concentrations in different chondrite groups.

In Table 9 and Table 10, along with the mean PGEs concentrations in some PGEs mineralization zones and deposits, sample concentrations are presented as well (especially for Alaska). It was done to perform the real comparison of PGEs contents in terrestrial deposits and samples with those in meteorites (e.g., chondrites). Since some meteorite groups (especially carbonaceous chondrites) are characterized by small number of examined meteorites which is not enough for 
Table 10. Moderate and elevated PGE contents in rock inclusions within ophiolites, serpentinites and peridotites (including samples).

\begin{tabular}{cccc}
\hline Area, region & Rock & $\Sigma$ PGE, ppm & Reference \\
\hline Skiros, Greece & chromite & 2.3 & {$[35]$} \\
Milia, Pindos, Greece & chromite & $\leq 1.059$ & {$[286]$} \\
Rhodope Massif, Bulgaria & chromitite & $\leq 1.6$ & {$[287]$} \\
Mawat ophiolite, Iraq & chromitites & $\leq 1.094$ & {$[145]$} \\
Oman ophiolite & chromitite & $\leq 1.5$ & {$[274]$} \\
Kempirsai Massif, Urals & chromitite & $\leq 1.0$ & {$[138]$} \\
Kempirsai Massif, Urals & chromite & $\leq 1.0-2.0$ & {$[288]$} \\
Polar Urals & sulfide-chromite & $0.7-0.8$ & {$[289]$} \\
Polar Urals & sulfide-bearing & $1.0-1.5$ & {$[289]$} \\
Eastern Desert, Egypt & dunite envelopes & up to 0.738 & {$[274]$} \\
Turkey ophiolites & Cr-PGE & $\leq 1.305$ & {$[290]$} \\
Eskişehir, Turkey & chromitites & $\leq 0.533$ & {$[291]$} \\
Loma Caribe, Dominican Republic & chromitites & $1.82-2.04$ & {$[292]$} \\
West Raglan, Cape Smith Belt, Canada & - & 2.54 & {$[293]$} \\
Avalon terrane, Canada & - & $\leq 2.4$ & {$[294]$} \\
Thetford Mines ophiolite, Canada & chromitite (Only Pt) & $\leq 2.0$ & {$[295]$} \\
Advocate ophiolite, Newfoundland, Canada & - & $\leq 1.028$ & {$[137]$} \\
Bird River Sill, Canada & chrome property & $\leq 0.7$ & {$[231]$} \\
Dovirensky layered complex, Siberia & (Pd only) & $\leq 1.4$ & {$[296]$} \\
Blue Ridge Province, North Carolina & chromite (Pt+Pd+Rh) & $\leq 0.746$ & {$[297]$} \\
Avan Hills, Alaska (Pt + Pd) & - & $\leq 1.029$ & {$[285]$} \\
Rabbit Creek, Alaska (Pt + Pd) & - & $\leq 2.298$ & {$[285]$} \\
Quartz Creek, Alaska (Pt only) & serpentinite & $\leq 1.2$ & {$[285]$} \\
Emerick prospect, Alaska (Pt + Pd) & serpentinite & $\leq 1.966$ & {$[285]$} \\
Red Mountain, Alaska (Pt only) & chromite (Pt only) & $\leq 1.337$ & {$[285]$} \\
\hline Chuck Mine, Alaska (Pd only) & - & 1.96 & {$[298]$} \\
Mar & - & 2.27 & {$[298]$} \\
\hline Mountain, Alaska & &
\end{tabular}

Table 11. High total PGEs contents in some chromites and/or chromitites related to ultramafic rocks but not enclosed in serpentinite layers.

\begin{tabular}{ccc}
\hline Area, region & $\Sigma$ PGE, ppm & Reference \\
\hline Lower Chromitite, Platreef, Bushveld Complex & $\leq 6.0$ & {$[166]$} \\
Upper Chromitite, Platreef, Bushveld Complex & up to $>11.0$ & {$[166]$} \\
Total UG2, Bushveld Complex & 5.7 & {$[42]$} \\
Chromites of India & $\leq 18.0$ & {$[302]$} \\
Chromite-sulphide, Orissa, India (Pt + Pd) & 11.18 & {$[303]$} \\
\hline
\end{tabular}

conventional statistical analysis, they should also be treated as samples. This is the reason why terrestrial samples with high, moderate and elevated PGEs should also be taken in consideration for comparison with PGEs concentrations in chondrites. Many cases of high PGEs contents related to sulfides in terrestrial 
rocks, even those which clearly associated with ultramafic rocks were not taken here in consideration, because our goal here is to analyze PGEs contents only in rocks directly associated to serpentinites/ophiolites. For comparison, average PGE contents for some known economic PGE deposits are presented in Table 13.

Table 12. Mean PGEs Total for the different chondrite groups (calculated using data of [47]).

\begin{tabular}{cc}
\hline Chondrite group & PGEs Total, ppm \\
\hline CI & 3.348 \\
CO & 4.481 \\
CM & 4.109 \\
CV & 5.074 \\
CK & 5.240 \\
CR & 4.145 \\
CH & 6.347 \\
CB & 9.605 \\
K & 2.205 \\
R & 2.161 \\
H & 5.303 \\
L & 3.589 \\
LL & 2.544 \\
L/LL & 3.071 \\
EH & 4.449 \\
EL & 4.127 \\
\hline
\end{tabular}

Table 13. Average PGE contents in some known terrestrial economic PGE deposits.

\begin{tabular}{ccc}
\hline Area, region & PGE, ppm & Reference \\
\hline Noril'sk, Russia & 10.03 & {$[42]$} \\
Monchegorsk, Russia, (NKT orebody) & 8.59 & {$[42]$} \\
Sudbury, Ontario & 1.173 & {$[42]$} \\
Great Dyke, South Africa & 5.418 & {$[42]$} \\
Total Merensky reef, Bushveld complex & 6.214 & {$[42]$} \\
Total UG-2 reef, Bushveld complex & 5.700 & {$[42]$} \\
Total Platreef, Bushveld complex & 4.121 & {$[42]$} \\
Total Bushveld complex & 5.670 & {$[42]$} \\
Stillwater, USA & 20.699 & {$[42]$} \\
Duluth Complex, Minnesota & $\mathrm{Pt}+\mathrm{Pd}=\sim 9$ & {$[190]$} \\
\hline
\end{tabular}

Comparison of data from Tables 9-12 indicates that in cases when PGEs contents in terrestrial rocks of the same values or even greater (in some cases much greater) than those in chondrites are not so rare. Even in some cases, PGE contents listed in Table 10 show that some of those amounts are pretty close to those of chondrites with low PGEs concentration. It is also clear that cases of PGEs contents listed in Tables 11-13 in general higher and in some cases much 
higher than those in chondrites (see Table 12). This simply means that if all economic deposits listed in Table 13 were entirely composed of CI chondrites they would not have medium PGEs contents which now recognized in the deposits.

Analysis of presence of chromite in carbonaceous and ordinary chondrites shows that: the Ivuna (CI1) carbonaceous chondrite contain chromite and olivine [304] and serpentine [305]; chromite and olivine and chromite-olivine pairs are presented in type II chondrules in $\mathrm{CM}, \mathrm{CO}, \mathrm{CV}, \mathrm{CR}, \mathrm{H}, \mathrm{L}, \mathrm{LL}$, and two ungrouped chondrites [306]; the Mokoia CV matrix contains chromite and chromites presented in partially characterized phases [307]; dissolution of samples from two Ivuna phases left behind a tiny acid-resistant residue highly enriched in Cr, most likely a chromite-spinel phase [308]; chromites were found in the Murchison CM2 chondrite [309]; chromite was found in powdered meteoritic material of carbonaceous chondrites [310]; in the Dhofar 225 CM chondrite olivine aggregates and chondrule-like olivine objects are common and the chondrules consist of olivine with minor chromite and sulfides [311]; chromite is presented in the carbonaceous chondrites but is considerably smaller than chromite in the ordinary chondrites $(25 \mu \mathrm{m}$ compared to $\sim 270 \mu \mathrm{m})$ [312]; Ramdohr [313] has investigated chromite in the Jilin chondrite which shows mostly coarse chromite (exsolution chromite), but with some grains too small to be included in the study; in NWA 4428 (CM2) chondrite grains as small as 11 $\mu \mathrm{m}, 16$ - $26 \mu \mathrm{m}$ were reported [312]; all chromite with a diameter larger than 10 $\mu \mathrm{m}$ in the Allende (CV3) chondrite is situated in porphyritic olivine chondrules, and Chromite grains smaller than $10 \mu \mathrm{m}$ (typically $1-3 \mu \mathrm{m}$ ) are also occurred in the porphyritic olivine chondrules [312]; the maximum diameter of chromite in the $\mathrm{L} 3$ chondrites is $34-50 \mu \mathrm{m}$, in the L4- $84-150 \mu \mathrm{m}$, in the L5- $76-158 \mu \mathrm{m}$ and in the L6- 253 - $638 \mu \mathrm{m}$ [314]; olivine and chromite are presented in the Tafassasset (CR?) chondrite [315]; the $\mathrm{H}$ chondrites contain $\sim 0.22 \mathrm{wt} \%$ chromite and the L chondrites contain about $\sim 0.27 \mathrm{wt} \%$ chromite [314]; chromite is the most common spinel group mineral in the ordinary chondrites [316]; chromite is more common in type $4-6$ ordinary chondrites than in type 3 ordinary chondrites [317].

These data clearly show that both chromite and olivine are presented in carbonaceous and ordinary chondrites and in carbonaceous chondrites chromite grains have limited size of microinclusions pretty similar to that of chromites and PGEs in the most of terrestrial deposits. Relatively huge size of some microinclusions in ordinary chondrites are of the same range or even smaller than size of grains of PGEs and chromites found in most of the Ural-Alaskan type mafic-ultramafic complexes (e.g., 0.5 - $2.0 \mathrm{~mm}$ in Yukon; [171]). Even presence of some extra carbonate in carbonaceous chondrites is not accidental, because formation of carbonate platforms is known in association with serpentinite and ophiolite belts [318].

There is some evidence of similarity of dunites from certain ophiolite belts with carbonaceous chondrites. Huang et al. [319] show that definite some cha- 
racteristics of chromites (e.g., ${ }^{187} \mathrm{Os} /{ }^{188} \mathrm{Os}$ ) from the Nagqu ophiolite (Tibet) suggest that the mantle source for the dunite is similar to that of the carbonaceous chondrites. Yang et al. [320] reported analysis of magnesium isotopic composition $\left(\delta^{26} \mathrm{Mg}\right)$ of mantle peridotite xenoliths from Sanyitang and Beiyan (North China craton) which are similar to $\delta^{26} \mathrm{Mg}$ values of two additional dunite standards (DTS-1 and DTS-2) and two carbonaceous chondrites (Allende and Murchison) analyzed in this study as well as $\delta^{26} \mathrm{Mg}$ of all published chondrites. Büchl et al. [321] presented results of research on evolution of Os isotope heterogeneities $\left({ }^{187} \mathrm{Os} /{ }^{188} \mathrm{Os}\right)$ in the mantle sequence of the Troodos ophiolite, Cyprus. The sequence of the Troodos ophiolite was divided into eastern (Unit 1) and western part (Unit 2) [322]. The results show that most of the ${ }^{187} \mathrm{Os} /{ }^{188} \mathrm{Os}$ ratios of Unit 1 lherzolites and harzburgites (with some dunites) are chondritic to subchondritic and most harzburgites and dunites of Unit 2 have suprachondritic ${ }^{187} \mathrm{Os} /{ }^{188} \mathrm{Os}$ ratios [321]. The spinel-lherzolites of Unit 1 have ${ }^{187} \mathrm{Os} /{ }^{188} \mathrm{Os}$ ratios $(0.1255$ $0.1276)$ similar to carbonaceous chondrites (0.127) and most of the harzburgites and dunites of Unit 2 have carbonaceous chondritic to suprachondritic ${ }^{187} \mathrm{Os} /{ }^{188} \mathrm{Os}$ ratios [321].

\section{Conclusion}

It is clear that there are too many similarities between the terrestrial rocks with PGE mineralization and deposits formed in association with serpentinites and/or ophiolites, and carbonaceous chondrites to merely be coincidental. All of the discussed above facts about the terrestrial PGE mineralization and deposits associated with serpentinites and/or ophiolites confirm that serpentine and olivine are the principal minerals in carbonaceous chondrites. Therefore, we can conclude that carbonaceous chondrites were formed from the ophiolite/serpentinite massifs of their parent objects. It should also be stated that since serpentinite and ophiolite massifs cannot represent all the different terrestrial rocks and rock associations, carbonaceous chondrites (and especially extremely rare CI chondrites) should not be used as a standard for the PGE contents in terrestrial rocks. The reasons why the extremely dense and heavy PGE did not sink to great depths at the time of the magma-ocean were discussed in detail. For example, the "late veneer" hypothesis of PGEs enrichment has been comprehensively examined. A significant role of ancient meteoritic bombardment in the creation of PGE deposits has been emphasized. Obviously, this last fact could assist in the development of new enhanced strategies for combined geological-geophysical prospecting for PGE deposits.

\section{References}

[1] Pilchin, A.N. and Eppelbaum, L.V. (2009) The Early Earth and Formation of the Lithosphere. In: Anderson, J.E. and Coates, R.W., Eds., The Lithosphere: Geochemistry, Geology and Geophysics, Nova Science Publication, New York, Chapter 1, 1-68.

[2] Maier, W.D. (2005) Platinum-Group Element (PGE) Deposits and Occurrences: Mineralization Styles, Genetic Concepts, and Exploration Criteria. Journal of Afri- 
can Earth Sciences, 41, 165-191. https://doi.org/10.1016/j.jafrearsci.2005.03.004

[3] Mungall, J.E. and Naldrett, A.J. (2008) Ore Deposits of the Platinum-Group Elements. Elements, 4, 253-258. https://doi.org/10.2113/GSELEMENTS.4.4.253

[4] Wyborn, L.A.I., Heinrich, C.A. and Jaques, A.L. (1994) Australian Proterozoic Mineral Systems: Essential Ingredients and Mappable Criteria. Proceedings of the Australian Institute of Miningand Metallurgy Annual Conference, Melbourne, 109-115.

[5] McQueen, K.G. (2005) Ore Deposit Types and their Primary Expressions. In: Cornelius, S.M. and Robertson, I.D.M., Eds., Regolith Expression of Australian Ore Systems: A Compilation of Exploration Case Histories with Conceptual Dispersion, Process and Exploration Models, CRC LEME, Australia, 1-14.

[6] Naldrett, A.J. (2004) Magmatic Sulfide Deposits: Geology, Geochemistry, and Exploration. Springer, Berlin. https://doi.org/10.1007/978-3-662-08444-1

[7] Hoatson, D.M. (1998) Platinum-Group Element Mineralization in Australian Precambrian Layered Mafic-Ultramafic Intrusions. AGSO Journal of Australian Geology and Geophysics, 17, 139-151.

[8] Naldrett, A.J. and Von Gruenewaldt, G. (1989) Association of Platinum-Group Elements with Chromitites in Layered Intrusions and Ophiolite Complexes. Economic Geology, 84, 180-187. https://doi.org/10.2113/gsecongeo.84.1.180

[9] Garuti, G., Pushkarev, V.E., Zaccarini, F., Cabella, R. and Anikina, E. (2002) Chromite-PGE Mineralization in the Uktus Alaskan-Type Complex (Central Urals, Russia). Transactions of the $9^{\text {th }}$ International Platinum Symposium, 149-152.

[10] Foose, M. and Weiblen, P. (1986) The Physical and Petrologic Setting and Textural and Compositional Characteristics of Sulfides from the South Kawishiwi Intrusion, Duluth Complex, Minnesota, USA. In: Friedrich, G.H., Genkin, A.D., Naldrett, A.J., Ridge, J.D., Sillitoe, R.H. and Vokes, F.M., Eds., Geology and Metallogeny of Copper Deposits, Special Publication No. 4 of the Socistu for Geology Applied to Min. Deposits. Springer, Berlin, 4, 8-24. https://doi.org/10.1007/978-3-642-70902-9 2

[11] Augé, T., Bailly, L., Cocherie, A., Genna, A., Guerrot, C., Lerouge, C., Mukherjee, M.M. and Patra, R.N. (2002) Magmatic and Hydrothermal Platinum-Group Element Mineralization in the Baula Area, Orissa, India. Transactions of the $9^{\text {th }}$ International Platinum Symposium, Billins, Montana, 21-24.

[12] Thakurta, J., Ripley, E.M. and Li, C. (2008) Pre-Requisites for Sulphide-Poor PGE and Sulphide-rich $\mathrm{Cu}-\mathrm{Ni}$-PGE Mineralization in Alaskan-Type Complexes. Journal of the Geological Society of India, 72, 611-622.

[13] Nemerov, V.K., Razvozzhaeva, E.A., Spiridonov, A.M. and Granina, E.M. (2008) By-Product Platinum Mineralization of Gold Ore Deposit Sukhoy Log (Eastern Siberia). In: Deposits of Natural and Technogenic Raw Materials: Geology, Geochemistry and Geophysical Methods and Ecologic Geology, Voronezh State University, 159-160. (In Russian)

[14] Vasilyeva, I.E., Pozhidaev, Yu.N., Vlasova, N.N., Voronkov, M.G. and Philipchenko, Yu.A. (2010) Sorption-Atomic-Emission Determination of Gold, Platinum and Palladium in Rocks and Ores Using Sorbent PSTM-3T. Analytical Controls, 14, 16-24. (In Russian)

[15] Chernyshov, N.M. (2004) Kshenskiy Type Gold-Platinum-Bearing Mineralization (Central Russia). Voronezh State University Bulletin, Geology, No. 1, 104-116. (In Russian)

[16] Chernyshov, N.M. and Chernyshova, M.N. (2012) Platinum-Bearing and Gold-Platinum-Bearing Formations of Voronezh Crystalline Massif at Different Geodynamic 
Regimes of Formation Precambrian Lithosphere. Lithosphere, No. 1, 122-146. (In Russian)

[17] Houlé, M.G. and Lesher, C.M. (2011) Komatiite-Associated Ni-Cu-(PGE) Deposits, Abitibi Greenstone Belt, Superior Province, Canada. Reviews in Economic Geology, 17, 89-121.

[18] Cawthorn, R.G. (2010) The Platinum Group Element Deposits of the Bushveld Complex in South Africa. Platinum Metals Review, 54, 205-215. https://doi.org/10.1595/147106710X520222

[19] Crowson, P. (2001) Minerals Handbook 2000-01: Statistics and Analyses of the World's Minerals Industry. Mining Journal Books Ltd., Edenbridge, Kent, UK.

[20] USGS (2005) Mineral Commodity Summaries. US Government Printing Office, Washington DC.

[21] Hedenquist, J.W. and Lowenstern, J.B. (1994) The Role of Magmas in the Formation of Hydrothermal Ore Deposits. Nature, 370, 519-527. https://doi.org/10.1038/370519a0

[22] Lide, D.R., Ed. (2004) Handbook of Chemistry and Physics. 85th Edition, CRC Press, Boca Raton.

[23] Lodders, K., Palme H. and Gail, H.P. (2009) Abundances of the Elements in the Solar System. In: Trumper, J.E., Ed., Astronomy and Astrophysics, Landolt-Bornstein, New Series, Vol. VI/4B, Chap. 4.4, Berlin, Springer-Verlag, 560-630.

[24] Wang, Yu., Wang, J., Wang, L., Long, L., Liao, Z., Zhang, H. and Tang, P. (2011) Problems of PGE Metallogenesis Related to Mafic-Ultramafic Complexes in North Xinjiang, China. Geoscience Frontiers, 2, 187-198. https://doi.org/10.1016/j.gsf.2011.03.008

[25] Pilchin, A.N. and Eppelbaum, L.V. (2006) Iron and Its Unique Role in Earth Evolution. Monograph, Mexican Geophys. Soc. 9, National University of Mexico.

[26] MacPherson, G.J. and Boss, A. (2011) Cosmochemical Evidence for Astrophysical Processes during the Formation of Our Solar System. PNAS, 108, 19152-19158. https://doi.org/10.1073/pnas.1110051108

[27] MacPherson, G.J., Simon, S.B., Davis, A.M., Grossman, L. and Krot, A.N. (2005) Calcium-Aluminum-Rich Inclusions: Major Unanswered Questions. In: Krot, A.N., Scott, E.R.D. and Reipurth, B., Eds., Chondrites and the Protoplanetary Disk, ASP Conf. Series, 341, 225-250.

[28] Weiser, T.W. and Bachmann, H.-G. (1999) Platinum Group Minerals from the Aikora River Area, Papua New Guinea. Canadian Mineralogist, 37, 1131-1145.

[29] Barkov, A.Y., Martin, R.F., LeBarge, W. and Fedortchouk, Y. (2008) Grains of Pt-Fe Alloy and Inclusions in a Pt-Fe Alloy from Florence Creek, Yukon, Canada: Evidence for Mobility of Os in a Na- $\mathrm{H}_{2} \mathrm{O}-\mathrm{Cl}$-Rich Fluid. Canadian Mineralogist, 46, 343- 360. https://doi.org/10.3749/canmin.46.2.343

[30] Bogdanov, K., Zaccarini, F., Garuti, G., Tzintsov, Z., and Ianakieva, N. (2012) Platinum Group Minerals (PGM) from Novoselsti Placers (Eastern Bulgaria): Evidence for a Ural-Alaskan-Type Intrusion? Transactions of the European Mineralogical Conference, 1, EMC2012-164.

[31] McDonough, W.F. and Sun, S.-S. (1995) The Composition of the Earth. Chemical Geology, 120, 223-253. https://doi.org/10.1016/0009-2541(94)00140-4

[32] Rudnick, R.L. and Gao, S. (2003) Composition of the Continental Crust. In: Rudnick, R.L., Ed., The Crust, 3, Ch. 3.01, Elsevier, 1-64. https://doi.org/10.1016/b0-08-043751-6/03016-4

[33] Morgan, J.W., Walker, R.J., Brandon, A.D. and Horan, M.F. (2001) Siderophile 
Elements in Earth's Upper Mantle and Lunar Breccias: Data Synthesis Suggests Manifestations of the Same Late Influx. Meteoritics \& Planetary Science, 36, 1257-1276. https://doi.org/10.1111/j.1945-5100.2001.tb01959.x

[34] Barnes, S-J. and Maier, W.D. (2002) Platinum-Group Element Distributions in the Rustenberg Layered Suite of the Bushveld Complex, South Africa. In: Cabri, L.J., Ed., The Geology, Geochemistry, Mineralogy and Mineral Beneficiation of Platinum-Group Elements. Canad. Inst. of Mining, Metallurgy and Petroleum, Special Vol. 54, 431-458.

[35] Economou-Eliopoulos, M. (2011) Platinum-Group Elements (PGE) in Various Geotectonic Settings: Opportunities and Risk. Hellenic Journal of Geosciences, 45, 65-82.

[36] Hauri, E.H. and Hart, S.R. (1997) Rhenium Abundances and Systematics in Oceanic Basalts. Chemical Geology, 139, 185-205. https://doi.org/10.1016/S0009-2541(97)00035-1

[37] Maier, W.D., Peltonen, P., McDonald, I., Barnes, S.J., Barnes, S.-J., Hatton, C. and Viljoen, F. (2012) The Concentration of Platinum-Group Elements and Gold in Southern African and Karelian Kimberlite-Hosted Mantle Xenoliths: Implications for the Noble Metal Content of the Earth's Mantle. Chemical Geology, 302-303, 119-135. https://doi.org/10.1016/j.chemgeo.2011.06.014

[38] Zientek, M.L. (2012) Magmatic ore Deposits in layered Intrusions-Descriptive Model for Reef-Type PGE and Contact-Type Cu-Ni-PGE Deposits. Open-File Report 2012-1010, United States Geological Survey, U.S. Department of the Interior.

[39] Voytekhovsky, Y.L. and Neradovsky, Y.N. (2008) The Cu-Ni-PGE and Cr Deposits of the Monchegorsk Area, the Kola Peninsula, Russia. 33 IGC Excursion No. 48, 15-21 August 2008, Oslo.

[40] Zaccarini, F., Garuti, G. and Pushkarev, E.V. (2010) Unusual PGE-Rich Chromitite in the "Butyrin-Veins" of the Kytlym Ural-Alaskan Complex (Northern Urals) Transactions of the $11^{\text {th }}$ INternational Platinum Symposium "PGE in the $21^{\text {st }}$ Century, Sudbury, Ontario, Canada.

[41] Prichard, H.M. and Lord, R.A. (1993) An Overview of the PGE Concentrations in the Shetland Ophiolite Complex. Geological Society, London, 76, 273-294. https://doi.org/10.1144/GSL.SP.1993.076.01.13

[42] Naldrett, A.J. (2010) Secular Variation of Magmatic Sulfide Deposits and Their Source Magmas. Economic Geology, 105, 669-688. https://doi.org/10.2113/gsecongeo.105.3.669

[43] Vikentyev, I.V., Yudovskaya, M.A., Mokhov, A.V., Kerzin, A.L. and Tsepin, A.I. (2004) Gold and PGE in Massive Sulfide Ore of the Uzalginsk Deposit, Southern Urals, Russia.Canadian Mineralogist, 42, 651-665. https://doi.org/10.2113/gscanmin.42.2.651

[44] Crocket, J.H. (1979) Platinum-Group Elements in Mafic and Ultramafic Rocks: A Survey. Canadian Mineralogist, 17, 391-402.

[45] Naldrett, A.J., Wilson, A., Kinnaird, J. and Chunnett, G. (2009) PGE Tenor and Metal Ratios within and below the Merensky Reef, Bushveld Complex: Implications for Its Genesis. Journal of Petrology, 50, 625-659.

https://doi.org/10.1093/petrology/egp015

[46] Barnes, S.-J., Maier, W.D. and Ashwal, L.D. (2004) Platinum-Group Element Distribution in the Main Zone and Upper Zone of the Bushveld Complex, South Africa. Chemical Geology, 208, 293-317. https://doi.org/10.1016/j.chemgeo.2004.04.018

[47] Tagle, R. and Berlin, J. (2008) A Database of Chondrite Analyses Including Plati- 
num Group Elements, $\mathrm{Ni}, \mathrm{Co}, \mathrm{Au}$, and $\mathrm{Cr}$ : Implications for the Identification of Chondritic Projectiles. Meteoritics \& Planetary Science, 43, 541-559. https://doi.org/10.1111/j.1945-5100.2008.tb00671.x

[48] McDonald, I. and Russell, S.S. (2001) Platinum-Group Elements in Enstatite Chondrites and Enstatite Achondrites. Meteoritics and Plan. Science, 36, A128.

[49] Kitts, K. and Lodders, K. (1998) Survey and Evaluation of Eucrite Bulk Compositions. Meteoritics \& Planetary Science, 33, A197-A213. https://doi.org/10.1111/j.1945-5100.1998.tb01334.x

[50] Neal, C.R., Taylor, L.A., Ely, J.C., Jain, J.C. and Nazarov, M.A. (2001) Detailed Geochemistry of New Shergottite, Dhofar 019 (Abstract). Lunar and Planetary Science, 32, \#1671, Lunar and Planetary Institute, Houston, Texas, USA (CDROM).

[51] McSween Jr., H.Y. (2008) Martian Meteorites as Crustal Samples. In: Bell, J., Ed., The Martian Surface: Composition, Mineralogy and Physical Properties, Cambridge University Press, Cambridge, 381-396. https://doi.org/10.1017/CBO9780511536076.018

[52] Anand, M., Taylor, L.A., Neal, C.R., Snyder, G.A., Patchen, A., Sano, Y. and Terada, K. (2003) Petrogenesis of Lunar Meteorite EET 96008. Geochimica et Cosmochimica Acta, 67, 3499-3518. https://doi.org/10.1016/S0016-7037(03)00134-0

[53] Snyder, G.A., Neal, C.R., Ruzicka, A.M. and Taylor, L.A. (1999) Lunar Meteorite EET 96008, PART II. Whole-Rock Trace-Element and PGE Chemistry, and Pairing with EET 87521. Lunar and Planetary Science, XXX, Abstract No. 1705.

[54] Mason, B. and Taylor, S.R. (1982) Inclusions in the Allende Meteorite. Smithsonian Contributions to the Earth Science, No. 25. Smithsonian Institution Press, Washington DC.

[55] Grossman, L. and Ganapathy, R. (1976) Trace Elements in the Allende Meteorite-I. Coarse-Grained, Ca-Rich Inclusions. Geochimica et Cosmochimica Acta, 40, 331 344. https://doi.org/10.1016/0016-7037(76)90211-8

[56] Connolly Jr., H.C., Huss, G.R. and Wasserburg, G.J. (2001) On the Formation of Fe-Ni Metal in Renazzo-Like Carbonaceous Chondrites. Geochimica et Cosmochimica Acta, 65, 4567-4588. https://doi.org/10.1016/S0016-7037(01)00749-9

[57] Weisberg, M.K., Smith, C., Benedix, G., Folco, L., Righter, K., Zipfel, J., Yamaguchi, A. and Chennaoui Aoudjehane, H. (2009) The Meteoritical Bulletin No. 95. Meteoritics and Planetary Science, 44, 429-462. https://doi.org/10.1111/j.1945-5100.2009.tb00742.x

[58] Lodders, K. (2003) Solar System Abundances and Condensation Temperatures of the Elements. The Astrophysical Journal, 591, 1220-1247. https://doi.org/10.1086/375492

[59] Palme, H. and Jones, A. (2005) Solar System Abundances of the Elements. In: Davis, A.M., Ed., Meteorites, Comets, and Planets. Treatise on Geochemistry 1, Elsevier, 41-62.

[60] McSween Jr., H.Y. (1999) Meteorites and Their Parent Planets. 2nd Edition, Cambridge University Press, Cambridge.

[61] Weisberg, M.K., McCoy, T.J. and Krot, A.N. (2006) Systematics and Evaluation of Meteorite Classification. In: Lauretta, D.S. and McSween Jr., H.Y., Eds., Meteorites and the Early Solar System II, The University of Arizona Press, 19-52.

[62] Zolensky M.E. and McSween, H.Y. (1988) Aqueous Alteration. In: Kerridge, J.F. and Matthews, M.S., Eds., Meteorites and the Early Solar System, University of Arizona Press, 114-143. 
[63] Krot, A.N., Hutcheon, I.D., Brearley, A.J., Pravdivtseva, O.V., Petaev, M.I. and Hohenberg, C.M. (2006) Timescales and Settings for Alteration of Chondritic Meteorites. In: Lauretta, D.S. and McSween, Jr., H.Y., Eds., Meteorites and the Early Solar System II. Univ. of Arizona Press, Tucson, 525-553.

[64] Drake, M.J. and Righter, K. (2002) Determining the Composition of the Earth. Nature, 416, 39-44. https://doi.org/10.1038/416039a

[65] Anderson, D.L. (2007) New Theory of the Earth. Cambridge University Press, Cambridge. https://doi.org/10.1017/CBO9781139167291

[66] Pilchin, A.N. (2011) Magnetite: The Story of the Mineral's Formation and Stability. In: Angrove, D.M., Ed., Magnetite: Structure, Properties and Applications, Nova Science Publication, New York, Chapter 1, 1-99.

[67] Norton, O.R. (2002) The Cambridge Encyclopedia of Meteorites. Cambridge University Press, Cambridge.

[68] Gupta, G. and Sahijpal, S. (2010) Differentiation of Vesta and the Parent Bodies of Other Achondrites. Journal of Geophysical Research: Planets, 115, E08001, 1-15. https://doi.org/10.1029/2009je003525

[69] Mason, B. (1972) The Mineralogy of Meteorites. Meteoritics, 7, 309-326. https://doi.org/10.1111/j.1945-5100.1972.tb00445.x

[70] Marvin, U.B. (2006) Meteorites in History: An Overview from the Renaissance to the $2^{\text {oth }}$ Century. In: McCall, G.J.H., Bowden, A.J. and Howarth, R.J., Eds., The History of Meteoritics and Key Meteorite Collections. Fireballs, Falls and Finds. Geological Society, Special Publication, London, 256, 15-71. https://doi.org/10.1144/GSL.SP.2006.256.01.02

[71] Grossman, L. (1973) Refractory Trace Elements in Ca-Al-Rich Inclusions in the Allende Meteorite. Geochimica et Cosmochimica Acta, 37, 1119-1140. https://doi.org/10.1016/0016-7037(73)90051-3

[72] Haack, H. and McCoy, T.J. (2005) Iron and Stony-Iron Meteorites. In: Holland, H.D. and Turekian, K.K., Eds., Treatise on Geochemistry, Elsevier, Amsterdam, 325 345.

[73] Chen, J.H., Papanastassiou, D.A. and Wasserburg, G.J. (2002) Re-Os and Pd-Ag Systematics in Group IIIAB Irons and in Pallasites. Geochimica et Cosmochimica Acta, 66, 3793-3810. https://doi.org/10.1016/S0016-7037(02)00952-3

[74] Mittlefehldt, D.W. (2005) Achondrites. In: Holland, H.D. and Turekian, K.K., Eds., Treatise on Geochemistry, Elsevier, Amsterdam, 291-324.

[75] Palme, H., Hutcheon, I.D. and Spettel, B. (1994) Composition and Origin of Refractory-Metal-Richassemblages in a Ca, Al-Rich Allende Inclusion. Geochimica et Cosmochimica Acta, 58, 495-513. https://doi.org/10.1016/0016-7037(94)90479-0

[76] Campbell, A.J., Simon, S.B., Humayun, M. and Grossman, L. (2003) Chemical Evolution of Metal in Refractory Inclusions in CV3 Chondrites. Geochimica et Cosmochimica Acta, 67, 3119-3134. https://doi.org/10.1016/S0016-7037(02)00837-2

[77] Pilchin, A.N. and Eppelbaum, L.V. (2012) The Early Earth, Formation and Evolution of the Lithosphere in the Hadean-Middle Archean. In: Sato, F. and Nakamura, Sh., Eds., Encyclopedia of Earth Science Research, 1, Chapter 1, 1-93.

[78] Eppelbaum, L.V., Kutasov, I.M. and Pilchin, A.N. (2014) Applied Geothermics. Springer, Berlin-Heidelberg. https://doi.org/10.1007/978-3-642-34023-9

[79] Pattou, L., Lorand, J.P. and Gros, M. (1996) Non-Chondritic Platinum-Group Element Ratios in the Earth's Mantle. Nature, 379, 712-715.

https://doi.org/10.1038/379712a0

[80] Ringwood, A.E. (1966) The Chemical Composition and Origin of the Earth. In: 
Hurley, P.M., Ed., Advances in Earth Science, M.I.T. Press, Cambridge, MA, 287356.

[81] Righter, K., Humayun, M. and Danielson, L. (2008) Partitioning of Palladium at High Pressures and Temperatures during Core Formation. Nature Geoscience, 1, 321-323. https://doi.org/10.1038/ngeo180

[82] Prescher, C., Cernok, A., Allu Peddinti, D., Bell, E.A., Wielicki, M.M., Bello, L., Ghosh, N., Tucker, J. and Zahnle, K.J. (2012) Origin and Mixing Timescale of Earth's Late Veneer. Transactions of the AGU Annual Fall Meeting, Abstract V51B2775.

[83] Lorand, J.-P., Alard, O., and Godard, M. (2009) Platinum-Group Element Signature of the Primitive Mantle Rejuvenated by Melt-Rock Reactions: Evidence from Sumail Peridotites (Oman Ophiolite). Terra Nova, 21, 35-40.

https://doi.org/10.1111/j.1365-3121.2008.00850.x

[84] Dauphas, N. and Marty, B. (2002) Inference on the Nature and the Mass of Earth's Late Veneer from Noble Metals and Gases. Journal of Geophysical Research, 107, 121-127. https://doi.org/10.1029/2001JE001617

[85] Maier, W.D., Barnes, S.J., Campbell, I.H., Fiorentini, M.L., Peltonen, P., Barnes, S.-J. and Smithies, R.H. (2009) Progressive Mixing of Meteoritic Veneer into the Early Earth's Deep Mantle. Nature, 460, 620-623. https://doi.org/10.1038/nature08205

[86] Eppelbaum, L.V. (2007) Localization of Ring Structures in Earth's Environments. Journal of the Archaeological Society of the Slovakian Academy of Science, Special Issue: Archaeological Prospection, XLI, 145-148.

[87] Cooper, G.R.J. (2010) Enhancing Circular Features in Potential Field Data. Exploration Geophysics, 41, 174-177. https://doi.org/10.1071/EG09039

[88] Eppelbaum, L.V. and Khesin, B.E. (2012) Geophysical Studies in the Caucasus. Springer, Heidelberg, New York. https://doi.org/10.1007/978-3-540-76619-3

[89] Elbeshausen, D., Wünnemann, K. and Collins, G.S. (2013) The Transition from Circular to Elliptical Impact Craters. Journal of Geophysical Research, 118, 1-15. https://doi.org/10.1002/2013je004477

[90] Koeberl, Ch. (2006) Impact Processes on the Early Earth. Elements, 2, 211-216. https://doi.org/10.2113/gselements.2.4.211

[91] Safronov, V.S. (1978) The Heating of the Earth during Its Formation. Icarus, 33, 3-12. https://doi.org/10.1016/0019-1035(78)90019-2

[92] Vacquier, V. (1998) A Theory of the Origin of the Earth's Internal Heat. Tectonophysics, 291, 1-7. https://doi.org/10.1016/S0040-1951(98)00026-2

[93] Abe, Y. (1997) Thermal and Chemical Evolution of the Terrestrial Magma Ocean. Physics of the Earth and Planetary Interiors, 100, 27-39. https://doi.org/10.1016/S0031-9201(96)03229-3

[94] Pollack, H.N. (1997) Thermal characteristics of the Archaean. In: de Wit, M.J. and Ashwal, M.D., Eds., Greenstone Belts, Clarendon Press, Oxford, 223-232.

[95] Solomatov, V.S. (2000) Fluid Dynamics of a Terrestrial Magma ocean, In: Canup, R. and Righter, K., Eds., Origin of the Earth and Moon. Univ. of Arizona Press, Tucson, Arizona, 323-338.

[96] Goldstein, J.I., Scott, E.R.D. and Chabot, N.L. (2009) Iron Meteorites: Crystallization, Thermal History, Parent Bodies, and Origin. Chemie der Erde, 69, 293-325. https://doi.org/10.1016/j.chemer.2009.01.002

[97] Alard, O., Griffin, W.L., Lorand, J.P., Jackson, S.E. and O'Reilly, S.Y. (2000) Non-Chondritic Distribution of the Highly Siderophile Elements in Mantle Sul- 
phides. Nature, 407, 891-894. https://doi.org/10.1038/35038049

[98] Sankaran, A.V. (2009) Komatiites through Time Reflect Trends in Mantle Incorporation of Meteoritic Platinum Group Elements. Current Science, 97, 1280-1281.

[99] Fiorentini, M.L., Barnes, S.J., Maier, W.D., Burnham, O.M. and Heggie, G. (2011) Global Variability in the Platinum-Group Element Contents of Komatiites. Journal of Petrology, 52, 83-112. https://doi.org/10.1093/petrology/egq074

[100] Tagle, R. and Claeys, Ph. (2005) An Ordinary Chondrite Impactor for the Popigai crater, Siberia. Geochimica et Cosmochimica Acta, 69, 2877-2889. https://doi.org/10.1016/j.gca.2004.11.024

[101] Firestone, R.B., West, A., Kennett, J.P., Becker, L., Bunch, T.E., Revay, Z.S., Schultz, P.H., Belgya, T., Kennett, D.J., Erlandson, J.M., Dickenson, O.J., Goodyear, A.C., Harris, R.S., Howard, G.A., Loosterman, J.B., Lechler, P., Mayewski, P.A., Montgomery, J., Poreda, R., Darrah, T., Que Hee, S.S., Smith, A.R., Stich, A., Topping, W., Wittke, J.H. and Wolbach, W.S. (2007) Evidence for an Extraterrestrial Impact 12,900 Years Ago That Contributed to the Megafaunal Extinctions and the Younger Dryas cooling. PNAS, 104, 16016-16021. https://doi.org/10.1073/pnas.0706977104

[102] Firestone, R.B. (2009) The Case for the Younger Dryas Extraterrestrial Impact Event: Mammoth, Megafauna, and Clovis Extinction, 12,900 Years Ago. Journal of Cosmology, 2, 256-285.

[103] Paquay, F.S., Goderis, S., Ravizza, G., Vanhaeck, F., Boyd, M., Surovell, T.A., Holliday, V.T., Haynes Jr., C.V. and Claeys, Ph. (2009) Absence of Geochemical Evidence for an Impact Event at the Bølling-Allerød/Younger Dryas Transition. PNAS, 106, 21505-21510. https://doi.org/10.1073/pnas.0908874106

[104] Shearer, C.K., Hess, P.C., Wieczorek, M.A., Pritchard, M.E., Parmentier, E.M., Borg, L.E., Longhi, J., Elkins-Tanton, L.T., Neal, C.R., Antonenko, I., Canup, R.M., Halliday, A.N., Grove, T.L., Hager, B.H., Lee, D.-C. and Wiechert, U. (2006) Thermal and Magmatic Evolution of the Moon. Reviews in Mineralogy and Geochemistry, 60, 365-518. https://doi.org/10.2138/rmg.2006.60.4

[105] Scoates, J.S. (2000) The Plagioclase-Magma Density Paradox Re-Examined and the Crystallization of Proterozoic Anorthosites. Journal of Petrology, 41, 627-649. https://doi.org/10.1093/petrology/41.5.627

[106] Pilchin, A.N. (2010) The Forsterite Layer and Density of Olivine under Lithospheric and Asthenospheric P-T-Conditions. Transations of the Annual Meeting GeoCanada, Calgary, Alberta (Abstract)

[107] Hewins, R.H., Jones, R.H. and Scott, E.R.D., Eds. (1996) Chondrules and the Protoplanetary Disk. Cambridge University Press, Cambridge.

[108] Davis, B.T.C. and England, J.L. (1964) The Melting of Forsterite up to 50 Kilobars. Journal of Geophysical Research, 69, 1113-1116. https://doi.org/10.1029/JZ069i006p01113

[109] Coombs, M.L. and Gardner, J.E. (2004) Reaction Rim Growth on Olivine in Silicic Melts-Implications for Magma Mixing. American Mineralogist, 89, 748-759. https://doi.org/10.2138/am-2004-5-608

[110] Shiraishi, Y., Ikeda, K., Tamura, A. and Saito, T. (1978) On the Viscosity and Density of the Molten $\mathrm{FeO}-\mathrm{SiO}_{2}$ System. Transactions of the Japan Institute of Metals and Materials, 19, 264-274. https://doi.org/10.2320/matertrans1960.19.264

[111] de Koker, N.P., Stixrude, L. and Karki, B.B. (2008) Thermodynamics, Structure, Dynamics, and Freezing of $\mathrm{Mg}_{2} \mathrm{SiO}_{4}$ Liquid at High Pressure. Geochimica et Cosmochimica Acta, 72, 1427-1441. https://doi.org/10.1016/j.gca.2007.12.019

[112] Lange, R.A. (1997) A Revised Model for the Density and Thermal Expansivity of $\mathrm{K}_{2} \mathrm{O}-\mathrm{Na}_{2} \mathrm{O}-\mathrm{CaO}-\mathrm{MgO}-\mathrm{Al}_{2} \mathrm{O}_{3}-\mathrm{SiO}_{2}$ Liquids from 700 to $1900 \mathrm{~K}$ : Extension to Crustal 
Magmatic Temperatures. Contributions to Mineralogy and Petrology, 130, 1-11. https://doi.org/10.1007/s004100050345

[113] Knittle, E. (1995) Static Compression Measurements of Equations of State. In: Ahrens, T.J., Ed., Mineral Physics and Crystallography. A Handbook of Physical Constants. American Geophysical Union, 98-142.

https://doi.org/10.1029/RF002p0098

[114] Ghiorso, M. (2004) An Equation of State for Silicate Melts. Parts I, III, IV. American Journal of Science, 304, 637-678, 752-810, 811-838. https://doi.org/10.2475/ajs.304.8-9.637

[115] Courtial, Ph., Ohtani, E. and Dingwell, D.R. (1997) High-Temperature Densities of Some Mantle Melts. Geochimica et Cosmochimica Acta, 61, 3111-3119. https://doi.org/10.1016/S0016-7037(97)00154-3

[116] Walker, D., Agee, C.B. and Zhang, Y. (1988) Fusion Curve Slope and Crystal/Liquid Buoyancy. Journal of Geophysical Research, 93, 313-323. https://doi.org/10.1029/JB093iB01p00313

[117] Hall, A. (1995) Igneous Petrology. Longman Scientific \& Technical, Singapore.

[118] Carmichael, R.S. Ed. (1982) Handbook of Physical Properties of Rocks, Vol. I. CRC Press, Baca Roton.

[119] Clark Jr., S.P., Ed. (1966) Handbook of Physical Constants. Revised Edition, Geological Society of America Memoirs 97, Washington DC.

[120] Adams, L.X. (1924) Temperatures at Moderate Depths within the Earth. Journal of the Washington Academy of Sciences, 14, 459-472.

[121] Clauser, Ch. (2009) Heat Transport Processes in the Earth's Crust. Surveys in Geophysics, 30, 163-191. https://doi.org/10.1007/s10712-009-9058-2

[122] Rubin, A.E. (2003) Chromite-Plagioclase Assemblages as a New Shock Indicator; Implications for the Shock and Thermal Histories of Ordinary Chondrites. Geochimica et Cosmochimica Acta, 67, 2695-2709. https://doi.org/10.1016/S0016-7037(03)00107-8

[123] Alexandrov, V.I., Gordon, V.G., Muraviev, E.N., Osiko, V.V., Prokhorov, A.M., Spiridonov, E.G. and Tatarintsev, V.M. (1977) Method of Synthesis of Metal Chromites. United States Patent 4035266.

[124] Bowen, N.L. and Tuttle, O.F. (1949) The System $\mathrm{MgO}-\mathrm{SiO}_{2}-\mathrm{H}_{2} \mathrm{O}$. Geological Society of America Bulletin, 60, 439-460. https://doi.org/10.1130/0016-7606(1949)60[439:TSM]2.0.CO;2

[125] Falloon, T.J., Green, D.H., Danyushevsky, L.V. and McNeill, A.W. (2008) The Composition of Near-Solidus Partial Melts of Fertile Peridotite at 1 and $1.5 \mathrm{GPa}$ : Implications for the Petrogenesis of MORB. Journal of Petrology, 49, 591-613.

https://doi.org/10.1093/petrology/egn009

[126] Azmon, E. (1965) Melting Temperature of Complex Silicates. Annals of the New York Academy of Sciences, 123, 481-494. https://doi.org/10.1111/j.1749-6632.1965.tb20379.x

[127] Canil, D. (1991) Experimental Evidence for the Exsolution of Cratonic Peridotite from High-Temperature Harzburgite. Earth and Planetary Science Letters, 106, 6472. https://doi.org/10.1016/0012-821X(91)90063-N

[128] Opta Minerals Inc. (2012) Chromite. http://www.optaminerals.com/Foundry/Chromite.html

[129] El-Rafei, E.A. (1971) Reversible Phase Transformation in the System Calcium Oxide-Chromium Sesquioxide-Oxygen. Jour. of Applied Chemistry and Biotechnology, 21, 261-265. https://doi.org/10.1002/jctb.5020210904 
[130] Mori, M., Yamamoto, T., Ichikawa, T. and Takeda, Y. (2002) Dense Sintered Conditions and Sintering Mechanisms for Alkaline Earth Metal ( $\mathrm{Mg}$, Ca and $\mathrm{Sr}$ )-Doped $\mathrm{LaCrO}_{3}$ Perovskites under Reducing Atmosphere. Solid State Ionics, 148, 93-101. https://doi.org/10.1016/S0167-2738(02)00109-1

[131] Crundwell, F., Moats, M., Ramachandran, V., Robinson, T. and Davenport, W.G. (2011) Extractive Metallurgy of Nickel, Cobalt and Platinum Group Metals. Elsevier.

[132] Morozova, L.V. and Popov, V.P. (2010) Synthesis and Investigation of Magnesium Chromium Spinel. Glass Physics and Chemistry, 36, 86-91. https://doi.org/10.1134/S1087659610010153

[133] Oo, W.W.K.K., Aye, Sh.W.H. and Lwin, K.T. (2008) Study on the Production of Chromite Refractory Brick from Local Chromite Ore. World Academy of Science, Engineering and Technology, 46, 569-574.

[134] Hockaday, S.A.C. and Bisaka, K. (2010) Sone Aspects of the Production of Ferrochrome Alloys in Pilot DC Arc Furnaces at Mintek. Proceedingas of the $12^{\text {th }}$ International Ferroalloys Congress, Helsinki, Finland, 367-376.

[135] Augustion, C.O., Prabhakaran, D. and Srinivasan, L.K. (1993) Fabrication and Characterization of $\mathrm{NiCr}_{2} \mathrm{O}_{4}$ Spinel. Journal of Materials Science Letters, 12, 383-386. https://doi.org/10.1007/BF00609161

[136] Song, S.-H., Yuan, Z.-X. and Xiao, P. (2003) Electrical Properties of $\mathrm{MnCr}_{2} \mathrm{O}_{4}$ Spinel. Journal of Materials Science Letters, 22, 755-757. https://doi.org/10.1023/A:1023764312610

[137] Escayola, M., Garuti, G., Zaccarini, F., Proenza, J.A., Bédard, J.H. and Van Staal, C. (2011) Chromitite and Platinum-Group-Element Mineralization at Middle Arm Brook, Central Advocate Ophiolite Complex, Baie Verte Peninsula, Newfoundland, Canada. Canadian Mineralogist, 49, 1523-1547. https://doi.org/10.3749/canmin.49.6.1523

[138] Melcher, F., Grum, W., Simon, G., Thalhammer, T.V. and Stumpfl, E.F. (1997) Petrogenesis of the Ophiolitic Giant Chromite Deposits of Kempirsai, Kazakhstan: A Study of Solid and Fluid Inclusions in Chromite. Journal of Petrology, 38, 14191458. https://doi.org/10.1093/petroj/38.10.1419

[139] Arif, M. and Qasim, J.M. (1993) Chemistry of Chromite and Associated Phases from the Shangla Ultramafic Body in the Indus Suture Zone of Pakistan. Geological Society, London, Special Publications, 74, 101-112. https://doi.org/10.1144/GSL.SP.1993.074.01.08

[140] Ligui, P. (1987) A Study on Inclusion in Chromite of Alpine-Type Ultrabasic Rocks in Western Jungar Area of Xinjiang, China. Acta Geosicientia Sinica, 9, 103-119.

[141] Ahmed, A.H., Arai, S. and Attia, A.K. (2001) Petrological Characteristics of Podiform Chromitites and Associated Peridotites of the Pan African Ophiolite Complexes of Egypt. Mineralium Deposita, 36, 72-84.

https://doi.org/10.1007/s001260050287

[142] Pushkarev, E.V., Anikina, E.V., Garuti, G. and Zaccarini, F. (2005) Postmagmatic Origin of Platinum Deposits in the Ural-Alaskan Type Ultramafites: $T-f \mathrm{O}_{2}$ Conditions and Role of Fluids. In: Törmänen, T.O. and Alapieti, T.T., Eds., Transactions of the $10^{\text {th }}$ International Platinum Symposium, 223-226.

[143] Nixon, G.T., Cabrill, J. and Gilles Laflamme, J.H. (1990) Platinum Group Element Mineralization in Lode and Placer Deposits Associated with the Tulameen Alaskan Type Complex, British Columbia. Canadian Mineralogist, 28, 503-535.

[144] Benham, A.J., Kovac, P., Petterson, M.G., Rojkovic, I., Styles, M.T., Gunn, A.G., 
McKervey, J.A. and Wasy, A. (2009) Chromite and PGE in the Logar ophiolite Complex, Afghanistan. Trans. of the Inst. of Mining and Metallurgy Section B Applied Earth Science, 118, 45-58.

[145] Ismail, S.A., Mirza, T.M. and Carr, P.F. (2010) Platinum-Group Elements Geochemistry in Podiform Chromitites and Associated Peridotites of the Mawat ophiolite, Northeastern Iraq. Journal of Asian Earth Sciences, 37, 3-41.

https://doi.org/10.1016/j.jseaes.2009.07.005

[146] Orovetskii, Yu.P. (1999) Mantle Plumes. A. A. Belkema, Rotterdam, The Netherlands.

[147] Marshall, J.S., Pounder, E.R. and Stewart, R.W. (1967) Physics. 2nd Edition, Macmillan of Canada, Toronto.

[148] Dingwell, D.B. and Mysen, B.O. (1985) Effects of Water and Fluorine on the Viscosity of Albite Melt at High Pressure: A Preliminary Investigation. Earth and Planetary Science Letters, 74, 266-274. https://doi.org/10.1016/0012-821X(85)90026-3

[149] Dingwell, D. B. (1987) Melt viscosities in the System $\mathrm{NaAlSi}_{3} \mathrm{O}_{8}-\mathrm{H}_{2} \mathrm{O}-\mathrm{F}_{2} \mathrm{O}_{-1}$. In: Mysen, B.O., Ed., Magmatic Processes. Physicochemical Principles. The Geochemical Society, Special Publication No. 1, 423-431.

[150] Toplis, M.J. Dingwell, D.B., Hess, K.-U. and Lenchi, T. (1997) Viscosity, Fragility, and Configurational Entropy of Melts along the Join $\mathrm{SiO}_{2}-\mathrm{NaAlSiO}_{4}$. American Mineralogist, 82, 979-990. https://doi.org/10.2138/am-1997-9-1014

[151] Scarfe, Ch.M. and Cronin, D.J. (1986) Viscosity-Temperature Relationships of Melts at $1 \mathrm{~atm}$ in the System Diopside-Albite. American Mineralogist, 71, 767-771.

[152] Hummel, W. and Arndt, J. (1985) Variation of Viscosity with Temperature and Composition in the Plagioclase System. Contrib. to Mineralogy and Petrology, 90, 83-92. https://doi.org/10.1007/BF00373044

[153] Deer, W.A., Zussman, J. and Howie, R.A. (2001) Rock-Forming Minerals: Framework Silicates: Feldspars. Vol. 4a, 2nd Edition, The Geological Society of London, London.

[154] Ganguly, J. (2008) Thermodynamics in Earth and Planetary Sciences. SpringerVerlag, Berlin-Heidelberg. https://doi.org/10.1007/978-3-540-77306-1

[155] Ashwal, L. (1998) Anorthosites: Classification, Mythology, Trivia, and a Simple Unified Theory. LPI Technical Report \#88-06. Houston, Texas, Lunar and Planetary Inst., 30-32.

[156] Shaw, H.R. (1972) Viscosities of Magmatic Silicate Liquids: An Empirical Method of Prediction. American Journal of Science, 272, 870-893. https://doi.org/10.2475/ajs.272.9.870

[157] Öhman, T. and Kring, D.A. (2012) Photogeologic Analysis of Impact Melt-Rich Lithologies in Kepler Crater That Could Be Sampled by Future Missions. Journal of Geophysical Research, 117, E00H08. https://doi.org/10.1029/2011JE003918

[158] Hiemstra, S.A. (1979) The Role of Collectors in the Formation of the Platinum Deposits in the Bushveld Cornplex. Canadian Mineralogist, 17, 469-482.

[159] Pilchin, A. (2005) The Role of Serpentinization in Exhumation of High- to Ultra-High-Pressure Metamorphic Rocks. Earth and Planetary Science Letters, 237, 815-828. https://doi.org/10.1016/j.epsl.2005.06.053

[160] Matveev, S. and Ballhaus, Ch. (2002) Role of Water in the Origin of Podiform Chromitite Deposits. Earth and Planetary Science Letters, 203, 235-243. https://doi.org/10.1016/S0012-821X(02)00860-9

[161] Prichard, H.M., Barnes, S.-J., Maier, W.D. and Fisher, P.C. (2004) Variations in the Nature of the Platinum-Group Minerals in a Cross-Section through the Merensky 
Reef at Impala Platinum: Implications for the Mode of Formation of the Reef. Canad. Mineralogist, 42, 423-437. https://doi.org/10.2113/gscanmin.42.2.423

[162] Page, P., Barnes, S.-J., Zientek, M.L., Prichard, H.M. and Fisher, P.C. (2009) IPGE (Os, Ir, Ru) Are Not in Chromite. Proceedings of $24^{\text {th }}$ IAGS (Fredericton), 197-200.

[163] Pagé, P., Barnes, S.-J., Zientek, M.L., Prichard, H.M. and Fisher, P.C. (2010) Chromite Does Not Control IPGE (Os, Ir, Ru). Proceedings of the $11^{\text {th }}$ International Platinum Symposium Ontario Geological Survey.

[164] Ballhaus, Ch. and Sylvester, P. (2000) Noble Metal Enrichment Processes in the Merensky Reef, Bushveld Complex. Journal of Petrology, 41, 545-561. https://doi.org/10.1093/petrology/41.4.545

[165] Economou-Eliopoulos, M., Eliopoulos, D.G. and Chryssoulis, S. (2008) A Comparison of High-Au Massive Sulfide Ores Hosted in Ophiolite Complexes of the Balkan Peninsula with Modern Analogues: Genetic Significance. Ore Geology Reviews, 33, 81-100. https://doi.org/10.1016/j.oregeorev.2006.10.009

[166] Yudovskaya, M., Kinnaird, J., Naldrett, A.J., Mokhov, A., Kuznetsova, M. and McDonald, I. (2010) Facies Variability of PGE Mineralization in Platreef Chromitites. Transactions of the $11^{\text {th }}$ INternational Platinum Symposium, Ontario Geological Survey.

[167] Huppert, H.E. and Sparks, R.S.J. (1985) Komatiites I: Eruption and Flow. Journal of Petrology, 26, 694-725. https://doi.org/10.1093/petrology/26.3.694

[168] Dingwell, D. B., Courtial, P., Giordano, D. and Nichols, A.R.L. (2004) Viscosity of Peridotite Liquid. Earth and Planetary Science Letters, 226, 127-138. https://doi.org/10.1016/j.epsl.2004.07.017

[169] Liebske, Ch., Schmickler, B., Terasaki, H., Poe, B.T. Suzuki, A., Funakoshi, K.-I., Ando, R. and Rubie, D.C. (2005) Viscosity of Peridotite Liquid up to 13 GPa: Implications for Magma Ocean Viscosities. Earth and Planetary Science Letters, 240, 589-604. https://doi.org/10.1016/j.epsl.2005.10.004

[170] Adjaoud, O., Steinle-Neumann, G. and Jahn, S. (2011) Transport Properties of $\mathrm{Mg}_{2} \mathrm{SiO}_{4}$ Liquid at High Pressure: Physical State of a Magma Ocean. Earth and Planetary Science Letters, 312, 463-470. https://doi.org/10.1016/j.epsl.2011.10.025

[171] Fedortchouk, Y., LeBarge, W., Barkov, A.Y., Fedele, L. and Bodnar, R.J. (2010) Major- and Trace-Element Composition of Platinum Group Minerals and Their Inclusions from Several Yukon Placers. In: MacFarlane, K.E., Weston, L.H. and Blackburn, L.R., Eds., Yukon Exploration and Geology 2009. Yukon Geological Survey, 185-196.

[172] Maier, W.D., de Klerk, L., Blaine, J., Manyeruke, T., Barnes, S.-J., Stevens, M.V.A. and Mavrogenes, J.A. (2008) Petrogenesis of Contact-Style PGE Mineralization in the Northern Lobe of the Bushveld Complex: Comparison of Data from the Farms Rooipoort, Townlands, Drenthe and Nonnenwerth. Mineralium Deposita, 43, 255 280. https://doi.org/10.1007/s00126-007-0145-3

[173] Cameron, E.N. (1977) Chromite in the Central Sector of the Eastern Bushveld Complex, South Africa. American Mineralogist, 62, 1082-1096.

[174] McDonald, I., Holwell, D.A. and Armitage, P.E.B. (2005) Stratigraphy and Platinum-Group Element Mineralization in the Northern Lobe of the Bushveld Complex, South Africa. In: Törmänen, T.O. and Alapieti, T.T., Eds., Transactions of the $10^{\text {th }}$ International Platinum Symposium, Extended Abstracts, 193-196.

[175] Boudreau, A. (1999) Fluid Fluxing of Cumulates: The J-M Reef and Associated Rocks of the Stillwater Complex, Montana. Journal of Petrology, 40, 755-772. https://doi.org/10.1093/petroj/40.5.755 
[176] Boudreau, A.E. and McCallum, I.S. (1986) Investigations of the Stillwater Complex; III, The Picket Pin Pt/Pd Deposit. Economic Geology, 8, 1953-1975. https://doi.org/10.2113/gsecongeo.81.8.1953

[177] Saini-Eidukat, B., Weiblen, P.W., Bitsianes, G. and Glascock, D. (1990) Contrasts between Platinum Group Element Contents and Biotite Compositions of Duluth Complex Troctolitic and Anorthositic Series Rocks. Mineralogy and Petrology, 42, 121-140. https://doi.org/10.1007/BF01162687

[178] Talkington, R.W. and Watkinson, D.H. (1984) Trends in the Distribution of the Precious Metals in the Lac-Des-Iles Complex, Northwestern Ontario. Canadian Mineralogist, 22, 125-136.

[179] Pettigrew, N.T. and Hattori, K.H. (2001) Geology of the Palladium-Rich Legris Lake Mafic-Ultramafic Complex, Western Wabigoon Subprovince, Northwestern Ontario. Exploration and Mining Geology, 10, 35-49. https://doi.org/10.2113/10.1-2.35

[180] Bayanova, T., Ludden, J. and Mitrofanov, F. (2009) Timing and Duration of Palaeoproterozoic Events Producing Ore-Bearing Layered Intrusions of the Baltic Shield: Metallogenic, Petrological and Geodynamic Implications. Geological Society, London, Special Publications, 323, 165-198. https://doi.org/10.1144/SP323.8

[181] Orsoev, D.A., Kislov, E.V. and Konnokov, E.G. (1995) PGE-Bearing Anorthosites of the Ioko-Dovyren Layered Massif, Northern Transbaikalia, Russia. In: Pašava, J., Kř́bek, B. and Žák, K., Eds., Mineral Deposits: From Their Origin to Their Environmental Impacts, A. A. Balkema, Rotterdam, The Netherlands, 181-182.

[182] Oktyabrsky, R.A., Solyanik, A.N., Lennikov, A.M., Gvozdev, V.I. and Ivanov, V.V. (2010) Compositional Variations in Platinum-Group Minerals and Gold in Lenses of Massive Pyrrhotite in the Dzhugdzhur Anorthosite, Far-Eastern Russia. Canad. Mineralogist, 48, 991-1004. https://doi.org/10.3749/canmin.48.4.991

[183] Latypov, R.M., Chistyakova, S.Yu. and Alapieti, T.T. (2008) PGE Reefs as an In Situ Crystallization Phenomenon: The Nadezhda Gabbronorite Body, Lukkulaisvaara Layered Intrusion, Fennoscandian Shield, Russia. Mineralogy and Petrology, 92, 211-242. https://doi.org/10.1007/s00710-007-0189-1

[184] Dora, M.L., Nair, K.K.K. and Shasidharan, K. (2011) Occurrence of Platinum Group Minerals in the Western Bastar Craton, Chandrapur District, Maharashtra. Current Science, 100, 399-405.

[185] Karazinov, N.V. (2005) Decriptometric Signs of presence Platinoid-Bearing Autonomous Anorthosites on Example of Geransky Massif (Far East). Proceedings of 9th International Scientific Symposium, Tomsk Polytechncal University, Tomsk, Russia. (In Russian)

[186] Collins, P.G. and Wilton, D.H.C. (2005) Evaluation and Characterization of the $\mathrm{Ni}-\mathrm{Cu}$ Sulfide and PGE Potential in Three Mafic-Ultramafic Intrusive Complexes: Preliminary Results. Current Research, Newfoundland and Labrador Department of Natural Resources, Geological Survey, Report 05-1, 131-149.

[187] Pilchin, A.N. (2014) The Involvement of Forsterite and Dunite Layers of the Oceanic Lithosphere in Obduction during Formation of the Appalachians. Geological Association of Canada and Mineralogical Association of Canada Joint Annual Meeting, Fredericton, 37, 223-224.

[188] Cawthorn, R.G. and Ashwal, L.D. (2009) Origin of Anorthosite and Magnetitite Layers in the Bushveld Complex, Constrained by Major Element Compositions of Plagioclase. Journal of Petrology, 50, 1607-1637.

https://doi.org/10.1093/petrology/egp042

[189] Severson, M.J. and Hauck, S.A. (2003) Platinum Group Elements (PGEs) and Platinum Group Minerals (PGMs) in the Duluth Complex. Minerals Coordinating 
Committee and the Natural Resources Research Inst. Technical Report NRRI/TR2003/37.

[190] Marma, J.C. (2002) Magmatic and Hydrothermal PGE Mineralization of the Birch Lake $\mathrm{Cu}-\mathrm{Ni}-\mathrm{PGE}$ Deposit in the South Kawishiwi Iutrusion, Duluth Complex, Northeast Minnesota. M.Sci. Thesis, University of Wisconsin, USA.

[191] Ghisler, M. (1976) The Geology, Mineralogy and Geochemistry of the Pre-Orogenic Archean Stratiform Chromite Deposits at Fiskenæsset, West Greenland. Monog. Series on Mineral Deposits, 14.

[192] Polat, A., Fryer, B.J., Appel, P.W.U., Kalvig, P., Kerrich, R., Dilek, Y. and Yang, Z. (2011) Geochemistry of Anorthositic Differentiated Sills in the Archean ( 2970 Ma) Fiskenæsset Complex, SW Greenland: Implications for Parental Magma Compositions, Geodynamic Setting, and Secular Heat Flow in Arcs. Lithos, 123, 50-72. https://doi.org/10.1016/j.lithos.2010.12.003

[193] Mukherjee, R., Mondal, S.K., Frei, R., Rosing, M.T., Waight, T.E., Zhong, H. and Kumar, G.R.R. (2012) The 3.1 Ga Nuggihalli Chromite Deposits, Western Dharwar craton (India): Geochemical and Isotopic Constraints on Mantle Sources, Crustal Evolution and Implications for Supercontinent Formation and Ore Mineralization. Lithos, 155, 392-409. https://doi.org/10.1016/j.lithos.2012.10.001

[194] Puchtel, I.S. and Humayun, M. (2001) Platinum Group Element Fractionation in a Komatiitic Basalt Lava Lake. Geochimica et Cosmochimica Acta, 65, 2979-2993. https://doi.org/10.1016/S0016-7037(01)00642-1

[195] Stephen, R., Sparks, J. and Huppert, H.E. (1984) Density Changes during the Fractional Crystallization of Basaltic Magmas: Fluid Dynamic Implications. Contributions to Mineralogy and Petrology, 85, 300-309. https://doi.org/10.1007/BF00378108

[196] Eales, H.V., Field, M., De Klerk, W.J. and Scoon, R. N. (1988) Regional Trends of Chemical Variation and Thermal Erosion in the Upper Critical Zone, Western Bushveld Complex. Mineralogical Magazine, 52, 63-79. https://doi.org/10.1180/minmag.1988.052.364.06

[197] Latypov, R.M., Chistyakova, S.Yu. and Alapieti, T.T. (2008) Fine-Grained Mafic Bodies as Preserved Portions of Magma Replenishing Layered Intrusions: The Nadezhda Gabbronorite body, Lukkulaisvaara Intrusion, Fennoscandian Shield, Russia. Mineralogy and Petrology, 92, 165-209. https://doi.org/10.1007/s00710-007-0190-8

[198] Papike, J., Ryder, G. and Shearer, Ch. (1998) Lunar Samples. Reviews in Mineralogy and Geochemistry, 36, 5.1-5.234.

[199] Czamanske, G.K. and Bohlen, S.R. (1990) The Stillwater Complex and Its Anorthosites: An Accident of Magmatic Underplating. American Mineralogist, 75, 37-45.

[200] Blatt, H. and Tracy, R.J. (1996) Petrology: Igneous, Sedimentary and Metamorphic. 2nd Edition, Macmillan, USA.

[201] Mottana, A., Crespi, R. and Liborio, G. (1977) Guide to Rocks and Minerals. Simon \& Schuster Inc., New York.

[202] Boudreau, A.E. and McCallum, I.S. (1984) The Picket Pin Pt/Pd Zone, Stillwater Complex, Montana. Lunar and Planetary Science, XV, 78-79.

[203] Mitchell, A.A. and Manthree, R. (2002) The Giant Mottled Anorthosite: A Transitional Sequence at the Top of the Upper Critical Zone of the Bushveld Complex. South African Journal of Geology, 105, 15-24. https://doi.org/10.2113/1050015

[204] Kruger, F.J. (2010) The Merensky and Bastard Cyclic Units and the Platreef of the Bushveld Complex: Consequences of Main Zone Magma Influxes and Dynamics. 
Transactions of the 4th International Platinum Conference, Platinum in Transition 'Boom or Bust', The South African Institute of Mining and Metallurgy, 43-46.

[205] Weiblen, P.W. and Morey, G.B. (1980) A Summary of the Stratigraphy, Petrology, and Structure of the Duluth Complex. American Journal of Science, 280-A, 88-133.

[206] Scoon, R.N. and Mitchell, A.A. (2004) The Platiniferous Dunite Pipes in the Eastern Limb of the Bushveld Complex: Review and Comparison with Unmineralized Discordant Ultramafic Bodies. South African Journal of Geology, 107, 505-520. https://doi.org/10.2113/gssajg.107.4.505

[207] Scoon, R.N. and Mitchell, A.A. (2011) The Principal Geological Features of the Mooihoek Platiniferrous Dunite Pipe, Eastern Limb of the Bushveld Complex, and Similarities with Replaced Merensky Reef at the Amandelbult Mine, South Africa. South African Journal of Geology, 114, 15-40. https://doi.org/10.2113/gssajg.114.1.15

[208] Scoon, R.N. and Mitchell, A.A. (2010) The Principal Geological Features of the Onverwacht Platiniferrous Dunite Pipe, Eastern Limb of the Bushveld Complex. South African Journal of Geology, 113, 155-168. https://doi.org/10.2113/gssajg.113.2.155

[209] Barnes, S.J. (1998) Chromite in Komatiites, 1. Magmatic Controls on Crystallization and Composition. Journal of Petrology, 39, 1689-1720.

https://doi.org/10.1093/petroj/39.10.1689

[210] Cotterill, P. (1969) The Chromite Deposits of Selukwe, Rhodesia. Transactions of Symposium on Magmatic Ore Deposits. Society of Economic Geologists. Monograph, 4, 154-186.

[211] Cotterill, P. (1979) The Selukwe Schist BELT and Its Chromitite Deposits. Geological Society of South Africa Special Publication, 5, 229-245.

[212] Hudgins, J.A., Walton, E.L. and Spray, J.G. (2007) Mineralogy, Petrology, and Shock History of Lunar Meteorite Sayh al Uhaymir 300: A Crystalline Impact-Melt breccia. Meteoritics \& Planetary Science, 42, 1763-1779.

https://doi.org/10.1111/j.1945-5100.2007.tb00536.x

[213] Scarfe, Ch.M., Cronin, D.J., Wenzel, J.T. and Kauffman, D.A. (1983) ViscosityTemperature Relationships at I atm in the System Diopside-Anorthite. American Mineralogist, 6E, 1083-1088.

[214] Williams-Jones, A.E. and Heinrich, Ch.A. (2005) Vapor Transport of Metals and the Formation of Magmatic-Hydrothermal Ore Deposits. Economic Geology, 100, 1287-1312. https://doi.org/10.2113/gsecongeo.100.7.1287

[215] Cawthorn, R.G. (2005) Stratiform Platinum-Group Element Deposits in Layered Intrusions. In: Mungall, J.E., Ed., Exploration for Platinum-Group Elements Deposits, Mineralogical Association of Canada, Short Course Series, 35, 57-73.

[216] Iljina, M.J. and Lee, C.A. (2005) Chapter 4: PGE Deposits in the Marginal Series of Layered Intrusions. In: Mungall, J.E., Ed., Exploration for Platinum-Group Element Deposits, Ottawa, Mineralogical Association of Canada Short Course Series, 35, 75 96.

[217] Starostin, V.I. and Sorokhtin, O.G. (2011) A New Interpretation for the Origin of the Norilsk Type PGE-Cu-Ni Sulfide Deposits. Geoscience Frontiers, 2, 583-591. https://doi.org/10.1016/j.gsf.2011.09.005

[218] Taylor Jr., H.P. (1967) The Zoned Ultramaphic Complexes of Southern Alaska. In: Wyllie, P.J., Ed., Ultramafic and Related Rocks, John Wiley \& Sons, New York, 97-121.

[219] Tolstykh, N.D., Sidorov, E.G. and Krivenko, A.P. (2005) Platinum-Group Element Placers Associated with Ural-Alaska Type Complexes. In: Mungall, J.E., Ed., Explo- 
ration for Platinum-Group Elements Deposits, Mineralogical Association of Canada Short Course Series, 35, 113-143.

[220] Wilde, A. (2005) Descriptive Ore Deposit Models: Hydrothermal and Supergene Pt \& Pd Deposits. In: Mungall, J.E., Ed., Exploration for Platinum-Group Elements Deposits, Mineralogical Association of Canada, Short Course Series, 35, 145-161.

[221] Melcher, F., Lodziak, J. and Oberthur, T. (2005) Modifications of Detrital PGM from the Eastern Bushveld Complex, South Africa. In: Törmänen, T.O. and Alapieti, T.T., Eds., Transactions of the 10th International Platinum Symposium, 201-204.

[222] Wilson, A.H. (1996) The Great Dyke of Zimbabwe. In: Cawthorn, R.G., Ed., Layered Intrusions, Elsevier, 365-402. https://doi.org/10.1016/S0167-2894(96)80013-3

[223] Li, C. and Ripley, E.M. (2006) Formations of Pt-Fe Alloy by Desulfurization of Pt-Pd Sulfide in the J-M Reef of the Stillwater Complex, Montana. Canadian Mineralogist, 44, 895-903. https://doi.org/10.2113/gscanmin.44.4.895

[224] Weiblen, P.W. and Morey, G.B. (1976) Textural and Compositional Characteristics of Sulfide Ores from the Basal Contact Zone of the South Kawiskiwi Intrusion, Duluth Complex, Northeastern Minnesota. Transactions of the 37 th Annual Mining Symposium, Minnesota Geological Survey, Minnesota University, Reprint No. 32.

[225] Watkinson, D.H. and Dunning, G. (1979) Geology and Platinum-Group Mineralization, Lac-Des-Iles Complex, Northwestern Ontario. Canadian Mineralogist, 17, 453-462.

[226] Sobolev, P.O. (1990) Orientation of Acicular Iron-Ore Mineral Inclusions in Plagioclase. Intern. Geology Review, 32, 616-628.

https://doi.org/10.1080/00206819009465804

[227] McKelson, J.F., Thalhammer, O.A.R. and Paliulionyte, V. (2005) The Dunite Complex of the Guli Massif, Northern Siberia, Russia: A Multidisciplinary Study. In: Törmänen, T.O. and Alapieti, T.T., Eds., Transactions of the 10th International Platinum Symposium, Extended Abstracts, 197-200.

[228] Varlakov, A.S. (1995) Riftogenic Ophiolites, Metamorphism of Hyperbasites and Structure of Vishnevogorsk-Il'menogorsky Complex. Institute of Mineralogy, The Urals Branch of the Russian Academy of Sciences. (In Russian)

[229] Varlakov, A.S. (1996) Riftogenic Ophiolites in Geological Evolution of the Earth. Bulletin of the Moscow Society of Nature Investigators, Series: Geology, 71, 19-30.

[230] Pilchin, A.N. (1986) On the Role of Pressures in Tectonic Processes. VINITI Press, Russian Academy of Sciences, No. 3723-86, 1-23.

[231] Pilchin, A.N. and Eppelbaum, L.V. (2002) Some Peculiarities of Thermodynamic Conditions of the Earth Crust and Upper Mantle. Scientific Israel, 4, 117-142.

[232] Peck, D.C. and Theyer, P. (1998) PGE-Copper-Nickel Potential of Mafic-Ultramafic Intrusions in the Bird River Greenstone Belt (Parts of NTS 52L). Manitoba Energy and Mines, Geological Services, Report of Activities, 151-160.

[233] Cameron, E.N. (1980) Evolution of the Lower Critical Zone, Central Sector, Eastern Bushveld Complex, and Its Chromite Deposits. Economic Geology, 75, 845-871. https://doi.org/10.2113/gsecongeo.75.6.845

[234] Hatton, C.J. and von Gruenewaldt, G. (1987) The Geological Setting and Petrogenesis of the Bushveld Chromitite Layers. In: Stowe, C.W., Ed., Evolution of Chromium Ore Fields. N. Y. Van Nostrand Reinhold, 109-143.

[235] Mondal, S.K. and Mathez, E.A. (2007) Origin of the UG2 Chromitite Layer, Bushveld Complex. Journal of Petrology, 48, 495-510.

https://doi.org/10.1093/petrology/egl069 
[236] Pilchin, A. and Pilchin, M. (2014) Repeating Obduction in the Process of Forming the Canadian Appalachians. Transactions of Geological Association of Canada and Mineralogical Association of Canada Joint Annual Meeting, Frederiction, 37, 222223.

[237] Pilchin, A.N. (1996) Tectonic and Petrologic Peculiarities of the Precambrian Evolution of the Baltic Shield. Transactions of the 58 th Conference of European Association of Geophysicists and Engineers, Amsterdam, The Netherlands, 513.

[238] Pilchin, M., and Pilchin, A. (1998) Some Peculiarities of Ocean Crust Activity in the Appalachian Region. Transactions of Geological Society of America Annual Meeting, Toronto, A-352.

[239] Hughes, S. and Luetgert, J. H. (1992) Crustal Structure of the Southeastern Grenville Province Northern New York State and Eastern Ontario. Journal of Geophysical Research, 97, 17455-17479. https://doi.org/10.1029/92JB01793

[240] Ebel, J.E. (2010) Resolving Lateral Variations in Upper Mantle Structure of Eastern North America: An Opportunity for USARRAY. Transactions of the 82 th Annual Meeting of the Eastern Section of the Seismological Society of America, Boston, 18-19 October 2010, 18.

[241] Németh, B., Clowes, R.M. and Hajnal, Z. (2005) Lithospheric Structure of the Trans-Hudson Orogen from Seismic Refraction-Wide-Angle Reflection Studies. Canadian Journal of Earth Sciences, 42, 435-456. https://doi.org/10.1139/e05-032

[242] Prodehl, C. and Mooney, W.D. (2012) Exploring the Earth's Crust: History and Results of Controlled-Source Seismology. The Geological Society of America, Memoir 208.

[243] Keen, M.J., Loncarevic, B.D. and Ewing, G.N. (2005) Continental Margin of Eastern Canada: Georges Bank to Kane Basin. In: Maxwell, A.E., Bullard, E. and Worzel, J.L., Eds., New Concepts of Sea Floor Evolution: Regional Observations Concepts, Harvard University Press, Ch. 7, 251-292.

[244] Dainty, A.M., Keen, C.E., Keen, M.J. and Blanchard, J.E. (1966) Review of Geophysical Evidence on Crust and Upper-Mantle Structure on the Eastern Seaboard of Canada. In: Steinhart, J.S. and Smith, T.J., Eds., The Earth Beneath the Continents, A Volume of Geophysical Studies in Honor of Merle A. Tuve, AGU, Geophys. Monogr. Ser., Washington, D. C., 10, 349-369.

[245] Rankin, D.S., Ravindra, R. and Zwicker, D. (1969) Preliminary Interpretation of the First Arrival Refraction Arrivals in Gaspé from Shots in Labrador and Quebec. Canadian Journal of Earth Sciences, 6, 771-774. https://doi.org/10.1139/e69-071

[246] Hughes, S., Hall, J. and Luetgert, J.H. (1994) The Seismic Velocity Structure of the Newfoundland Appalachian Orogen. Journal of Geophys. Research: Solid Earth, 99, 13633-13653. https://doi.org/10.1029/94JB00653

[247] Chian, D., Marillier, F., Hall, J. and Quinlan, G. (1998) An Improved Velocity Model for the Crust and Upper Mantle along the Central Mobile Belt of the Newfoundland Appalachian Orogen and Its Offshore Extension. Canadian Journal of Earth Sciences, 35, 1238-1251. https://doi.org/10.1139/e98-042

[248] Max, M.D. and Ohta, Y. (1988) Did Major Fractures in Continental Crust Control Orientation of the Knipovich Ridge-Lena Trough Segment of the Plate Margin? Polar Research, 6, 85-93. https://doi.org/10.3402/polar.v6i1.6848

[249] Mjelde, R., Goncharov, A. and Dietmar Müller, R. (2013) The Moho: Boundary above Upper Mantle Peridotites or Lower Crustal Eclogites? A Global Review and New Interpretations for Passive Margins. Tectonophysics, 609, 636-650. https://doi.org/10.1016/j.tecto.2012.03.001

[250] Van Avendonk, H.J.A., Holbrook, W.S., Okaya, D., Austin, J.K., Davey, F. and 
Stern, T. (2004) Continental Crust under Compression: A Seismic Refraction Study of South Island Geophysical Transect I, South Island, New Zealand. Journal of Geophys. Research, 109, B06302. https://doi.org/10.1029/2003jb002790

[251] Kostyuchenko, S.L., Fedorow, D.L., Solodilov, L.N., Egorkin, A.V. and Zolotov, E.E. (1999) Deep Structure and Evolution for the Pre-Caspian Basin. Transactions of the $E U G, 10$, Strasbourg, France, 4, G01, 3A/14, G3.

[252] Piip, V.B., Rodnikov, A.G. and Buvaev, N.A. (2012) The Deep Structure of the Lithosphere along the Caucasus-South Caspian Basin-Absheron Threshold-Middle Caspian Basin-Turan Plate Seismic Profile. Moscow University Geology Bulletin, 67, 125-132. https://doi.org/10.3103/S0145875212020068

[253] De Souza, S., Tremblay, A., Ruffet, G. and Pinet, N. (2012) Ophiolite Obduction in the Quebec Appalachians, Canada-40Ar/39Ar Age Constraints and Evidence for Syn-Tectonic Erosion and Sedimentation. Canadian Journal of Earth Sciences, 49, 91-110. https://doi.org/10.1139/e11-037

[254] Hannan, B.B. and Sinha, A.K. (1989) Petrology and Tectonic Affinity of the Baltimore Mafic Complex, Maryland. In: Mittwede, S.K. and Stoddard, E.F., Eds., UItramafic Rocks of the Appalachian Piedmont. Geological Society of America Special Paper 231, 1-18. https://doi.org/10.1130/SPE231-p1

[255] Laurent, R. and Hébert, Y. (1979) Paragenesis of Serpentine Assemblages in Harzburgite Tectonite and Dunite Cumulate from the Quebec Appalachians. Canadian Mineralogist, 17, 857-869.

[256] Condie, K.C. and Madison, J.A. (1969) Compositional and Volume Changes Accompanying Progressive Serpentinization of Dunites from the Webster-Addie Ultramafic Body, North Carolina. American Mineralogist, 51, 1173-1179.

[257] Minarik, W.G., Gale, A. and Booker, C. (2003) Mont Albert to Buck Mountain: Provenance of Appalachian Ophiolite Chromites Using Osmium Isotopes. Transactions of the American Geophysical Union Fall Meeting, Abstract \#V11E-0534.

[258] Salisbury, M.H. and Christensen, N.I. (1985) Olivine Fabrics in the Bay of Islands Ophiolite: Implications for Oceanic Mantle Structure and Anisotropy. Canadian Journal of Earth Sciences, 22, 1757-1766. https://doi.org/10.1139/e85-186

[259] Paiement, J.-Ph., Gagne, J., Duplessis, C., Rousseau, G., Gagnon, G. and Dagbert, M. (2013) Pre-Feasibility Study Mine Arnaud Inc. Sept-Iles Deposit, Québec. Final Report. SGS Canada Inc.

[260] Page, P., Bedard, J.H., Tremblay, A. and Schroetter, J. (2003) The Thetford Mines Ophiolite Complex: Focus on the Petrology, Mineralogy and Geochemistry (REE, PGE) of a Supra-Subduction Mantle Section. Transactions of the American Geophysical Union, Fall Meeting, Abstract \#V22H-01.

[261] Scott, P.W., Jackson, T.A. and Dunham, A.C. (2000) Ore Mineral Associations and Industrial Minerals in the Ultramafic Rocks of Jamaica and Tobago. Caribbean Journal of Earth Science, 34, 5-16.

[262] Sole, J.P.J. and Melgarejo, J.C. (1999) Uvarovite in Podiform Chromitite: The Moa-Baracoa Ophiolitic Massif, Cuba. Canadian Mineralogist, 37, 679-690.

[263] Brem, A.G., Lin, S. and van Staal, C.R. (2002) Humber Zone-Dunnage Zone Relationships and the Long Range Fault, South of Grand Lake, Western Newfoundland: Preliminary Results. In: Current Research. Newfoundland and Labrador Department of Mines and Energy, Geological Survey Branch, Report: 02-1, 135-144.

[264] Pettingill, H.S., Sinha, A. K. and Tatsumoto, M. (1984) Age and Origin of anorthosites, Charnockites, and Granulites in the Central Virginia Blue Ridge: Nd and $\mathrm{Sr}$ Isotopic Evidence. Contributions to Mineralogy and Petrology, 85, 279-291. https://doi.org/10.1007/BF00378106 
[265] Murthy, G.S. and Rao, K.V. (1976) Paleomagnetism of Steel Mountain and Indian Head Anorthosites from Western Newfoundland. Canadian Journal of Earth Sciences, 13, 75-83. https://doi.org/10.1139/e76-007

[266] Haworth, R.T. (1978) Interpretation of Geophysical Data in the Northern Gulf of St. Lawrence and Its Relevance to Lower Paleozoic Geology. Geological Society of America Bulletin, 89, 1091-1110. https://doi.org/10.1130/0016-7606(1978)89<1091:IOGDIT>2.0.CO;2

[267] Rao, K.V. and Van der Voo, R. (1980) Paleomagnetism of a Paleozoic Anorthosite from the Appalachian Piedmont, Northern Delaware: Possible Tectonic Implications. Earth and Planetary Science Letters, 47, 113-120. https://doi.org/10.1016/0012-821X(80)90109-0

[268] McLelland, J.M., Selleck, B.W., Hamilton, M.A. and Bickford, M.E. (2010) Late-to Post-Tectonic Setting of Some Major Proterozoic Anorthosite-MangeriteCharnockite-Granite (AMCG) Suites. Canadian Mineralogist, 48, 1025-1046. https://doi.org/10.3749/canmin.48.4.729

[269] Aleinikoff, J.N., Horton Jr., J.W. and Walter, M. (1996) Middle Proterozoic Age for the Montpelier Anorthosite, Goochland Terrane, Eastern Piedmont, Virginia. Geological Society of America Bulletin, 108, 1481-1491. https://doi.org/10.1130/0016-7606(1996)108<1481:MPAFTM >2.3.CO;2

[270] Crawford, W.A., Robelen, P.G. and Kalmbach, J.H. (1971) The Honey Brook Anorthosite. American Journal of Science, 271, 333-349. https://doi.org/10.2475/ajs.271.4.333

[271] Owens, B.E., Iriarte, K.E. and Dymek, R.F. (2004) The Smallest, but Most Potassic Massif Anorthosite on Earth: Geochemistry of the Montpalier Pluton, Goochland Terrane, Virginia. Geological Society of America, Denver Annual Meet. Abstracts with Programs, 36, 220.

[272] John, J.St. (2012) Rocks from Ophiolites. http://www.newark.osu.edu/facultystaff/personal/jstjohn/Documents/Cool-Rocks/ Ophiolite-rocks.htm

[273] Barnes, S. and Jones, S. (2013) Deformed Chromitite Layers in the Coobina Intrusion, Pilbara Craton, Western Australia. Economic Geology, 108, 337-354. https://doi.org/10.2113/econgeo.108.2.337

[274] Hutcinson, Ch.S. (1972) Alpine-Type Chromite in North Borneo, with Special Reference to Darvel Bay. American Mineralogist, 57, 835-856.

[275] Page, P., Barnes, S.J. and Cox, R. (2007) Laser Ablation Study of Trace Elements in Chromite: Thetford Mines Ophiolite Chromitite Ores. Geochimica et Cosmochimica Acta, 71, A748-A748.

[276] Tsoupas, G. and Economou-Eliopulos, M. (2008) High PGE Contents and Extremely Abundant PGE-Minerals Hosted in Chromitites from the Veria Ophiolite Complex, Northern Greece. Ore Geology Reviews, 33, 3-19. https://doi.org/10.1016/j.oregeorev.2006.10.008

[277] Ahmed, A.H. and Arai, S. (2003) Platinum-Group Elements Mineralogy of Late Proterozoic Podiform Chromitites from the Eastern Desert of Egypt: A Preliminary Result. Proceed. of $7^{\text {th }}$ Biennial SGA Meeting, Athens, Greece. In: Eliopoulos, et al., Eds., Mineral Exploration and Sustainable Development, Millpress, Rotterdam, 555-558.

[278] Kapsiotis, A., Grammatikopoulos, T.A., Tsikouras, B. and Hatzipanagiotou, K. (2009b) Platinum-Group Mineral Characterization in Concentrates from HighGrade PGE Al-Rich Chromitites of Korydallos Area in the Pindos Ophiolite Com- 
plex (NW Greece) Resource Geology, 60, 178-191.

https://doi.org/10.1111/j.1751-3928.2010.00124.x

[279] Zaccarini, F., Garuti, G. and Pushkarev, E.V. (2011) Unusually PGE-Rich Chromitite in the Butyrin Vein of the Kytlym Uralian-Alaskan Complex, Northern Urals, Russia. Canadian Mineralogist, 49, 1413-1431. https://doi.org/10.3749/canmin.49.6.1413

[280] Zaccarini, F., Pushkarev, E.V., Fershtater, G.B. and Garuti, G. (2004) Composition and Mineralogy of PGE-Rich Chromitites in the Nurali Lherzolite-Gabbro Complex, Southern Urals, Russia. Canadian Mineralogist, 42, 545-562. https://doi.org/10.2113/gscanmin.42.2.545

[281] González-Jiménez, J.M., Augé, T., Gervilla, F., Bailly, L., A. Proenza, J. and Griffin, W.L. (2011) Mineralogy and Geochemistry of Platinum-Rich Chromitites from the Mantle-Crust Transition Zone at Quin Island, New Caledonia Ophiolite. Canad. Mineralogist, 49, 1549-1569. https://doi.org/10.3749/canmin.49.6.1549

[282] Prichard, H.M., Neary, C.R., Fisher, P.C. and O’Hara, M.J. (2008) PGE-Rich Podiform Chromitites in the Al'Ays Ophiolite Complex, Saudi Arabia: An Example of Critical Mantle Melting to Extract and Concentrate PGE. Economic Geology, 103, 1507-1529. https://doi.org/10.2113/gsecongeo.103.7.1507

[283] Çina, A., Neziraj, A., Karaj, N., Johan, Z. and Ohnenstetter, M. (2002) PGE Mineralization Related to Albanian Ophiolitic Complex. Geologica Carpathica, 53, 1-7.

[284] Routledge, R.E., Cox, J.J., Scott, K.C. and Hwozdyk, L.R. (2010) Technical Report on the Lac Des Iles Mine Property. Thunder Bay, Ontario, Canada. NI 43-101 Report.

[285] Prichard, H.M., Fisher, P.C., McDonald, I., Zhou, M.-F. and Wang, C.Y. (2005) Platinum-Group Minerals in the Jinchuan Complex, China. In: Törmänen, T.O. and Alapieti, T.T., Eds., Transactions of the 10th International Platinum Symposium, 219-222.

[286] Smith II, R.C. and Barnes, J.H. (2011) Geochemistry and Mineralogy of Platinum Group Elements in Some Chromite Occurrences in the State Line District, Chester and Lancaster Counties, Pennsylvania. Pennsylvania Geology, 41, 3-13.

[287] Gervilla, F., Frei, R., González-Jiménez, J.M., Garrido, C.J., Proenza, J., Melgarejo, J.C., Meibom, A., Batista, J.A. and Ruiz, R. (2005) Platinum-Group Elements and Os Isotope Systematics in Chromite Ores from Mayarí-Baracoa Ophiolitic Belt (Eastern Cuba). Transactions of the 10 th International Platinum Symposium, Oulu, Finland, 86-89.

[288] Foley, J.Y. (1991) Metallogeny of Ophiolitic and Other Mafic-Ultramafic Terranes in Alaska. US Department of the Interior, Geological Survey. US Bureau of Mines Unpublished Report.

[289] Kapsiotis, A., Grammatikopoulos, T.A., Tsikouras, B., Hatzipanagiotou, K., Zaccarini, F. and Garuti, G. (2009a) Chromian Spinel Composition and Platinum-Group Element Mineralogy of Chromitites from the Milia Area, Pindos Ophiolite Complex, Greece. Canadian Mineralogist, 47, 1037-1056.

https://doi.org/10.3749/canmin.47.5.1037

[290] Gervilla, F., Frei, R., González-Jiménez, J.M., Kerestedjian, T. and Glavev, B. (2008) Geochemistry of platinum Group Elements in Chromitites from the Rhodope Massif (Bulgaria). Revista de la Sociedad Española de Mineralogía, No. 9, 115-116.

[291] Volchenko, Yu.A., Koroteev, V.A. and Neustroeva, I.I. (2009) Platinum-Group Elements in Alpine-Type Ultramafic Rocks and Related Chromite Ores of the Main Ophiolite Belt of the Urals. Geology of Ore Deposits, 51, 162-178.

https://doi.org/10.1134/S1075701509020068 
[292] Gurskaya, L.I., Smelova, L.V. and Shahova, S.N. (2005) PGE Mineralization Associated with Ultramafic Intrusions of the Polar Urals: New Data to Beneficiation. In: Törmänen, T.O. and Alapeiti, T.T., Eds., Trans. of the $10^{\text {th }}$ Intern. Plat. Symp. "Platinum-Group Elements-From Genesis to Beneficiation and Environmental Impact", Finland, 359-361.

[293] Uysal, I., Sadiklar, M.B., Zaccarini, F., Garuti, G., Tarkian, M. and Meisel, T. (2010) Cr-PGE Mineralization in the Turkish Ophiolites. Transactions of the State of Art, 11 th International Platinum Symposium, 1-3.

[294] Uysal, I., Zaccarini, F., Sadiklar, M.B., Tarkian, M., Thalhammer, O.A.R. and Garuti, G. (2009) The Podiform Chromitites in the Dagküplü and Kavak Mines, Eskişehir Ophiolite (NW-Turkey): Genetic Implications of Mineralogical and Geochemical data. Geologica Acta, 7, 351-362.

[295] Proenza, J.A., Zaccarini, F., Lewis, J.F., Longo, F. and Garuti, G. (2007) Chromian Spinel Composition and the Platinum-Group Minerals of the PGE-Rich Loma Peguera Chromitites, Loma Caribe Peridotite, Dominican Republic. Canadian Mineralogist, 45, 631-648. https://doi.org/10.2113/gscanmin.45.3.631

[296] Jowitt, S.M., Keays, R.R. and Peck, D.C. (2010) New Insights into the Geology and Mineral Potential of the West Raglan Ni-Cu-PGE Project, Cape Smith Fold Belt, Ontario Geological Survey, Miscellaneous Release-Data.

[297] Paktunc, A.D. (1990) Comparative Geochemistry of platinum-Group Elements of Nickel-Copper Sulfide Occurrences Associated with Mafic-Ultramafic Intrusions in the Appalachian Orogen. Journal of Geochemical Exploration, 37, 101-111. https://doi.org/10.1016/0375-6742(90)90085-O

[298] Tanguay, S. and Hebert, R. (1990) Distribution of PGE in Pyroxene-Bearing Ultramafic Cumulates in the Thetford Mines ophiolitic Complex, Quebec. Canadian Mineralogist, 28, 597-605.

[299] Papunen, H., Distler, V. and Sokolov, A. (1992) PGE in the Upper Proterozoic Dovirensky Layered Complex, North Baikal Area, Siberia. Australian Journal of Earth Sciences, 39, 327-334. https://doi.org/10.1080/08120099208728027

[300] Lipin, B.R. (1984) Chromite from the Blue Ridge Province of North Carolina. Amer. Journal of Science, 284, 507-529. https://doi.org/10.2475/ajs.284.4-5.507

[301] Lasley, S. (2012) From Placer Streams to Historical Mines, Hints of Elusive Metal span Alaska. Petroleum News, Newspaper, Anchorage, Alaska.

[302] Sahoo, R.K., Mohanty, J.K., Das, S.K. and Paul, A.K. (2009) Chromites of India Their Textural and Mineralogical Characteristics. ISMO-2009. Transactions of the International Symposium on Magmatic Ore Deposits. Bhubaneswar, Orissa, India.

[303] Mondal, S.K. and Baidya, T.K. (1997) Platinum-Group Minerals from the Nuasahi Ultramafic-Mafic Complex, Orissa, India. Mineralogical Magazine, 61, 902-906. https://doi.org/10.1180/minmag.1997.061.409.13

[304] Endress, M. and Bischoff, A. (1993) Mineralogy, Degree of Brecciation, and Aqueous Alteration of CI Chondrites Orgueil, Ivuna, and Alais. Meteoritics, 28, 345-346.

[305] Brearley, A.J. (1992) Mineralogy of Fine-Grained Matrix in the Ivuna CI Carbonaceous Chondrite. Lunar and Planetary Science, 23, 153-154.

[306] Johnson, C.A. and Prinz, M. (1991) Chromite and Olivine in Type II Chondrules in Carbonaceous and Ordinary Chondrites: Implications for Thermal Histories and Group Differences. Geochimica et Cosmochimica Acta, 55, 893-904. https://doi.org/10.1016/0016-7037(91)90349-A

[307] Buseck, P.R. and Hua, X. (1993) Matrices of Carbonaceous chondrite Meteorites. 
Annual Review of Earth and Planetary Sciences, 21, 255-305. https://doi.org/10.1146/annurev.ea.21.050193.001351

[308] Shukolyukov, A., Lugmair, G.W. and Bogdanovski, O. (2003) Manganese-Chromium Isotope Systematics of Ivuna, Kainsaz and Other Carbonaceous Chondrites. Lunar and Planetary Science, XXXIV, Abstract 1279.

[309] Cloutisa, E.A., Hiroi, T., Gaffey, M.J. and Alexander, C.M. O’D. and Mann, P. (2011) Spectral Reflectance Properties of Carbonaceous Chondrites: 1. CI Chondrites. Icarus, 212, 180-209. https://doi.org/10.1016/j.icarus.2010.12.009

[310] Visa, R.D. and Heymann, D. (1999) On the Q-Phase of Carbonaceous Chondrites. Nuclear Instruments and Methods in Physics Research B, 158, 538-543. https://doi.org/10.1016/S0168-583X(99)00512-1

[311] Ivanova, M.A., Taylor, L.A., Clayton, R.N., Mayeda, T.K., Nazarov, M.A., Brandstätter, F. and Kurat, G. (2002) Dho 225 vs. the CM Clan: Metamorphosed or New Type of Carbonaceous Chondrite. $33^{\text {rd }}$ Lunar and Planetary Science Conferences, Abstract \#1437. CD-ROM.

[312] Riebe, M. (2009) Spinel Group Minerals in Carbonaceous and Ordinary Chondrites. BA Thesis, Lunds University, No. 250.

[313] Ramdohr, P. (1973) The Opaque Minerals in Stony Meteorites. Elsevier, Amsterdam.

[314] Bridges, J.C., Schmitz, B., Huchison, R., Greenwood, R.C., Tassinari, M. and Franchi, I.A. (2007) Petrographic Classification of Middle Ordovician Fossil Meteorites from Sweden. Meteoritics and Planetary Science, 42, 1781-1789. https://doi.org/10.1111/j.1945-5100.2007.tb00537.x

[315] Göpel, C., Birck, J.-L. and Zanda, B. (2011) Mn/Cr Systematics in Carbonaceous chondrites: Mineral Isochrons versus Stepwise Dissolution. Mineralogical Magazine, 7, A32.

[316] Rubin, A.E. (1997) Mineralogy of Meteorite Groups. Meteoritics \& Planetary Science, 32, 231-247. https://doi.org/10.1111/j.1945-5100.1997.tb01262.x

[317] Wlotzka, F. (2005) Cr Spinel and Chromite as Petrogenetic Indicators in Ordinary Chondrites: Equilibrium Temperatures of Petrologic Types 3.7 to 6. Meteoritics and Planetary Science, 40, 1673-1702. https://doi.org/10.1111/j.1945-5100.2005.tb00138.x

[318] Khain, V.Ye. (1984) Regional Geotectonics-Alpine Mediterranean Belt. Nedra, Moscow. (In Russian)

[319] Huang, Q.S., Shi, R.D., Liu, D.L., Zhang, X.R., Fan, S.Q. and Ding, L. (2013) Os Isotopic Evidence for a Carbonaceous Chondritic Mantle Source for the Nagqu Ophiolite from Tibet and Its Implications. Chinese Science Bulletin, 58, 92-98. https://doi.org/10.1007/s11434-012-5384-8

[320] Yang, W., Teng, F.-Zh. and Zhang, H.-F. (2009) Chondritic Magnesium Isotopic Composition of the Terrestrial Mantle: A Case Study of Peridotite Xenoliths from the North China Craton. Earth and Planetary Science Letters, 288, 475-482. https://doi.org/10.1016/j.epsl.2009.10.009

[321] Büchl, A., Brügmann, G.E., Batanova, V.G. and Hofmann, A.W. (2003) Os Mobilization during Melt Percolation: The Evolution of Os Isotope Heterogeneities in the Mantle Sequence of the Troodos Ophiolite, Cyprus. Geochimica et Cosmochimica Acta, 68, 3397-3408. https://doi.org/10.1016/j.gca.2004.02.005

[322] Batanova, V.G. and Sobolev, A.V. (2000) Compositional Heterogeneity in Subduction-Related Mantle Peridotites, Troodos massif, Cyprus. Geology, 28, 55-58. https://doi.org/10.1130/0091-7613(2000)28<55:CHISMP $>2.0$. CO;2 
Submit or recommend next manuscript to SCIRP and we will provide best service for you:

Accepting pre-submission inquiries through Email, Facebook, LinkedIn, Twitter, etc. A wide selection of journals (inclusive of 9 subjects, more than 200 journals)

Providing 24-hour high-quality service

User-friendly online submission system

Fair and swift peer-review system

Efficient typesetting and proofreading procedure

Display of the result of downloads and visits, as well as the number of cited articles Maximum dissemination of your research work

Submit your manuscript at: http://papersubmission.scirp.org/

Or contact nr@scirp.org 